\title{
Folic acid, folate and homocysteine: Human intervention studies
}

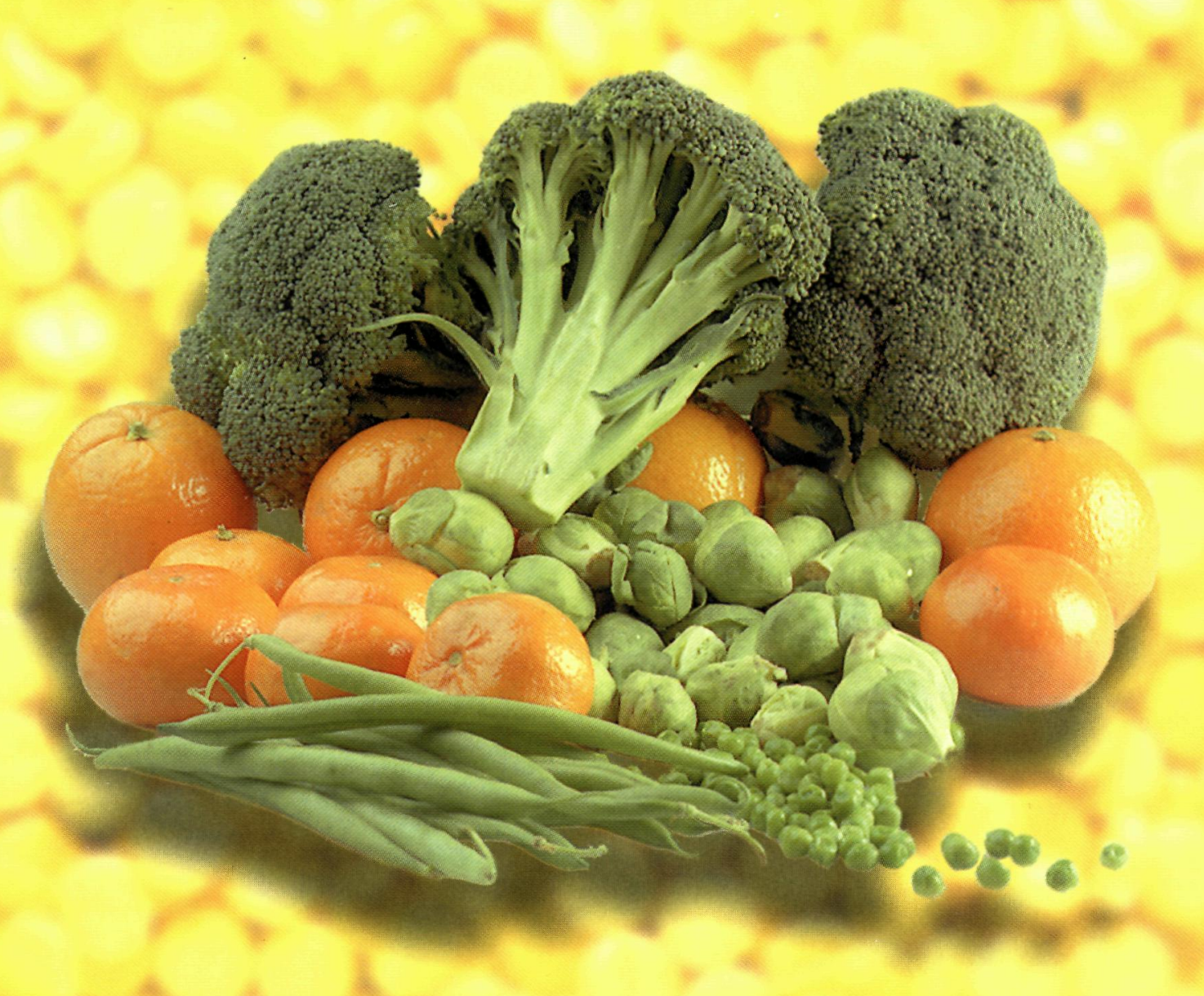

Ingeborg A Brouwer 

Folic acid, folate and homocysteine: Human intervention studies

Ingeborg A Brouwer 



\section{Folic acid, folate and homocysteine: Human intervention studies}

Een wetenschappelijke proeve op het gebied van de Medische Wetenschappen

\section{PROEFSCHRIFT}

ter verkrijging van de graad van doctor aan de Katholieke Universiteit Nijmegen, volgens besluit van het College van Decanen in het openbaar te verdedigen op

donderdag 1 juli 1999

des namiddags om 12:30 uur precies

door

\section{INGEBORG ANNEMARIE BROUWER}

geboren op 4 oktober 1968 te Apeldoorn 
Promotores:

Co-promotores:
Prof. Dr T.K.A.B. Eskes

Prof. Dr J.G.A.J. Hautvast (Wageningen Agricultural University)

Dr R.P.M. Steegers-Theunissen

Dr Ir M. van Dusseldorp (Wageningen Agricultural University)

Manuscriptcommissie: Prof. Dr J.B.M.J. Jansen

Prof. Dr Ir J.M.F. Trijbels

Prof. Dr Ir G.A. Zielhuis

Prof. Dr D. Van der Heide (Wageningen Agricultural University)

Dr H. van den Berg (CIVO/TNO, Zeist)

The research described in this thesis was conducted within a collaborative project of the Department of Obstetrics and Gynaecology of the University Hospital Nijmegen St Radboud and the Division of Human Nutrition and Epidemiology of the Wageningen Agricultural University. It was part of the research program of the Graduate School VLAG.

The studies presented in this thesis were financially supported by grant number 282559 of the Dutch 'Praeventiefonds', The Hague, the Netherlands.

Publication of this thesis was financially supported by the Dutch 'Praeventiefonds'. Their support is gratefully acknowledged.

Folic acid, folate and homocysteine: Human intervention studies.

Ingeborg A Brouwer.

Thesis Katholieke Universiteit Nijmegen - With ref. - With summary in Dutch. ISBN: 90-9012689-9.

Cover design: Boudewijn van Veen, Ton Feijen \& Ingeborg Brouwer.

Printing: Grafisch Bedrijf Ponsen \& Looijen BV, Wageningen, the Netherlands.

(c) Ingeborg A Brouwer 
Fiffy years after its first discovery and synthesis, folate is coming of age with the recognition that folate is important not only in the most widespread form of vitamin-related anemia in the world, but also in four conditions as dreaded as the horsemen of the apocalypse: cancer, heart disease, stroke, and neural tube defects (IIwin H Rosenberg, Am J Clin Nutr 1997, 65 162-3). 



\section{Abstract}

\section{Folic acid, folate and homocysteine: Human intervention studies}

PhD Thesis by Ingeborg A Brouwer, Department of Obstetrics and Gynaecology, University Hospital Nijmegen St Radboud, Nijmegen, and Division of Human Nutrition and Epidemiology, Wageningen University, Wageningen, the Netherlands

An elevated plasma total homocysteine concentration is a risk factor for women for having offspring with a neural-tube defect, and for both men and women for cardiovascular diseases Extra intake of folic acid decreases plasma total homocysteıne concentrations and has been proven to contribute to the prevention of neural-tube defects Studies on the role of folıc acid in preventing cardiovascular diseases are underway

In this thesis we investigated whether low doses of supplemental folic acid (tablets) and folates in foods improve blood folate status and decrease plasma total homocysteine concentrations We also studied a mechanism by which inadequate supply of folate to the foetus could be a risk factor for spina bifida, a neural-tube defect

A daily intake of $250 \mu \mathrm{g}$ of supplemental folıc acid for four weeks was sufficient to improve folate status and decrease plasma total homocysteıne concentrations in healthy young women in a dietary controlled experiment, we showed that not only intake of supplemental folic acid, but also intake of folate derived from vegetables and citrus fruit improved the folate status and decreased plasma total homocysteıne concentratıons

Folate and plasma total homocysteıne concentratıons of spına bifida patients were comparable to those of control patients Four weeks of supplementation with $500 \mu \mathrm{g}$ of folic acid per day improved the folate status and decreased plasma total homocysteine concentrations to a sımilar extent in the two groups

In conclusion, we found no indication that an impaired folate and homocysteıne metabolism in spına bifida patıents is an important risk factor for having a neural-tube defect

A high intake of dietary folate from vegetables and citrus fruit improves folate status and decreases plasma total homocysteıne concentrations, which may lower the risk of cardıovascular diseases and of having offspring with a neural-tube defect This provides a new argument for advising the general population to increase their intake of vegetables and fruits However, women plannıng to become pregnant should still be advised to take supplemental folic acid as well Folate from foods may prevent neural-tube defects but folıc acıd supplements have been proven to do so 



\section{Contents}

\section{Abbreviations}

1. Introduction

2. Low-dose folic acid supplementation decreases plasma homocysteine: a randomized trial

3. Low-dose folic acid supplementation does not influence plasma methionine concentrations in young non-pregnant women

4. Homocysteine-lowering effect of $500 \mu \mathrm{g}$ of folic acid every other day versus $250 \mu \mathrm{g}$ per day

5. Homocysteine metabolism and effects of folic acid supplementation in patients affected with spina bifida

6. Dietary folate from vegetables and citrus fruit decreases plasma homocysteine concentrations: a dietary controlled trial

7. Bioavailability and bioefficacy of folate and folic acid: Review of the literature

8. General Discussion

References

Summary

Samenvatting

Dankwoord

Curriculum Vitae

Publications 


\section{List of abbreviations}

$\mu \mathrm{g} / 2 \mathrm{~d}=$ microgram per 2 days

$\mu \mathrm{g} / \mathrm{d}=$ microgram per day

$\mathrm{B} 12=$ vitamın $\mathrm{B} 12$

$\mathrm{B} 6=$ vitamin $\mathrm{B} 6$

BHMT = betaine homocysteIne methyltransferase

$\mathrm{CS}=$ cystathınıne synthase

$\mathrm{CV}=$ coefficient of variance

DHFR = dihydrofolate reductase

$\mathrm{H}_{2}$ PteGlu = dihydrofolate

$\mathrm{H}_{4}$ PteGlu = tetrahydrofolate

MS = methionıne synthase

MTHFR = methylenetetrahydrofolate reductase

PLP = pyridoxal-5' - phosphate

PteGlu = pteroylglutamate

PteGlu ${ }_{1}=$ pteroylmonoglutamate (= folic acıd)

PteGlu $u_{n}=$ pteroylglutamate with side chain containing between 1 and 7 glutamates tHcy = plasma total homocysteine 
1

Introduction 


\section{Rationale and objectives}

Folate is the generic name for all derivatives of the B-vitamin with the biological activity of pteroylmonoglutamic acid (FAO, 1988). Folic acid is the fully oxidised monoglutamate form of the vitamin, whereas the other naturally occurring forms are referred to as folates. Folic acid supplementation around conception decreases the risk of having offspring with a neural-tube defect (Czeizel and Dudás, 1992; MRC Vitamin Study Research Group, 1991). Therefore, in 1993 the Food and Nutrition Council in the Netherlands advised all women planning to become pregnant to consume folic acid preparations to prevent neural-tube defects. Women who have not previously given birth to a child with a neural-tube defect are advised to take a tablet containing 400 to $500 \mu \mathrm{g}$ of folic acid each day from at least four weeks before pregnancy until at least the eighth week of pregnancy (Food and Nutrition Council, 1993). Although lower doses may be effective, no randomised trials have been carried out to test whether this is indeed the case. The underlying mechanism of the preventive effect of folic acid is unclear.

Folate in food occurs in many different forms. It is unclear whether high intakes of folate from food can also prevent neural-tube defects. Furthermore, it is difficult for women to reach a daily intake of $400 \mu \mathrm{g}$ of dietary folate. The average intake is only about $250 \mu \mathrm{g}$ per day (de Bree et al., 1997). On the other hand, not all women in the target group do take folic acid tablets around conception (de Jong-van den Berg et al., 1998; Sayers et al., 1997).

Women who previously gave birth to a child with a neural-tube defect were shown to have elevated plasma total homocysteine concentrations (Mills et al., 1995; Steegers Theunissen et al., 1994). Moreover, an elevated plasma total homocysteine concentration is an established risk factor for cardiovascular diseases (Boushey et al., 1995). In a meta-analysis Boushey et al. (1995) estimated that a plasma total homocysteine concentration of $15 \mu \mathrm{mol} / \mathrm{L}$ is associated with a $43 \%$ higher risk for coronary heart disease in men than a concentration of $10 \mu \mathrm{mol} / \mathrm{L}$. Intakes of folic acid in doses above $650 \mathrm{\mu g}$ have been shown to decrease plasma total homocysteine concentrations and may thereby reduce the risk of cardiovascular diseases (Ubbink, 1997). Less is known about the homocysteine-lowering effect of lower doses of folic acid or dietary folate.

Most studies which have investigated the effect of folic acid supplementation on plasma total homocysteine concentration have focused on persons with plasma total homocysteine concentrations above the normal range (Brattström et al., 1988; 
Guttormsen et al , 1996, Ubbınk et al , 1993, Ubbınk et al, 1994) Refsum et al (1998) concluded from a review of the literature that the relationship between plasma total homocysteine level and cardiovascular disease is continuous without an apparent threshold Therefore, it would be worthwhile to investigate the effect of intake of folic acid and dietary folate on total plasma homocysteıne concentratıons in subjects with plasma total homocysteıne concentrations in the normal range

Thus, this thesis has the following objectives

1 To investigate whether supplementation with low doses of folic acid improves the folate status and decreases plasma total homocysteine concentrations in healthy subjects

2 To study the underlying mechanısm by which additional folic acid around the time of conception prevents neural-tube defects More specifically, whether folate and homocysteine metabolism of patients with spina bifida differs from that of control subjects and whether folic acid supplementation in spina bifida patients improves their folate status and decreases their plasma total homocysteine concentrations

3 To investigate whether intake of folate from vegetables and citrus fruit improves the folate status and decreases plasma total homocysteine concentrations in healthy subjects and to relate such effects to those obtained with the ingestion of folic acid

This introduction will provide background information on several aspects of synthetic folic acid and naturally occurring folates Then, the metabolism of homocysteine will be described This is followed by a description of the consequences of a low folate Intake for neural-tube defects and cardiovascular diseases Subsequently, the strengths and weaknesses of study designs generally used in human intervention studies are discussed Finally, the introduction ends with the outline of the thesis

\section{Folate and its metabolism}

\section{Nomenclature}

Folate is the generic term for all compounds of the B-vitamın that exhibit vitamın activity similar to pteroyImonoglutamic acid (folic acıd) (Figure 11 ) In this thesis folic acid refers to the fully oxidised pteroyimonoglutamic acid Folic acid is not a natural compound and it is much more stable than most reduced forms (O'Broin et al, 1975) The synthetic form of this vitamin is used in tablets and fortified foods 
In nature the pteridine ring of folate is reduced to either dihydrofolate $\left(\mathrm{H}_{2}\right.$ PteGlu $)$ or tetrahydrofolate $\left(\mathrm{H}_{4}\right.$ PteGlu) The tetrahydrofolates are present unsubstituted or with various one-carbon groups (Figure 12) Natural folates often exist as polyglutamates (PteGlun $)$, with a side chain of up to seven glutamate residues in $\gamma$-peptide linkage in the human body folate is transported across membranes as monoglutamates (PteGlu) Only monoglutamates are found in plasma and urine in tissues folates are synthesised to polyglutamates Polyglutamates are in general better substrates for enzymes than monoglutamates (Wagner, 1995) In food folates mainly occur as polyglutamates

Figure 1.1 Structure of tetrahydrofolate From Shane (1995)

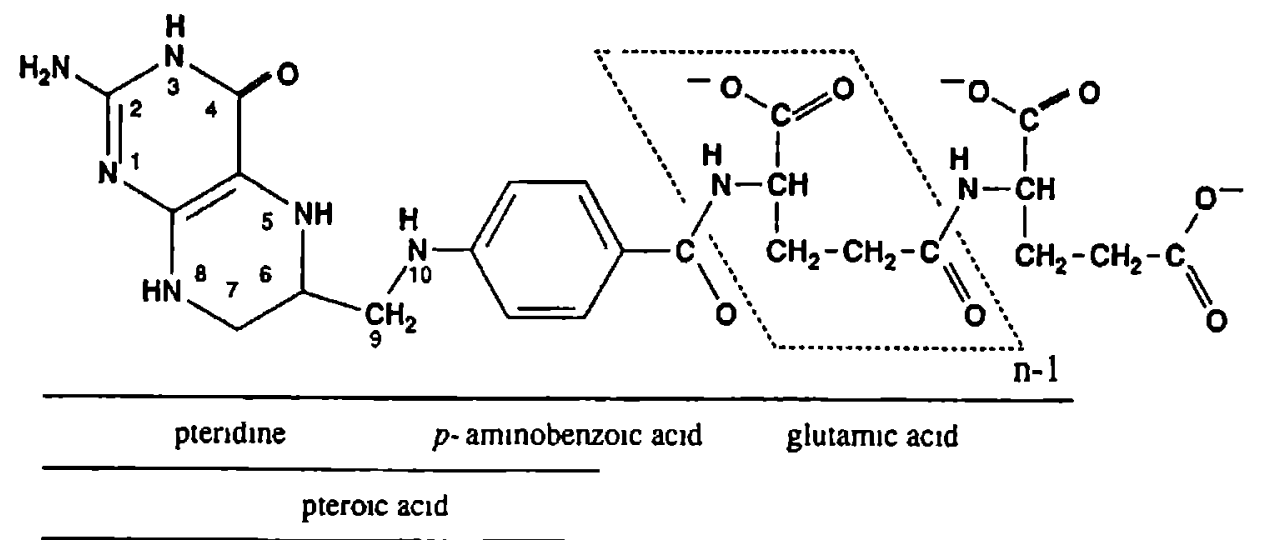

pteroylglutamic acid

\section{Folate one-carbon pool}

The main function of folate is to carry one-carbon moieties, such as methyl and formyl groups These one-carbon groups are used in the synthesis of DNA precursors Figure 12 depicts the reactions and enzymes involved in one-carbon metabolism The folates in this figure are shown as monoglutamates, though, as mentioned before, most folates in human tissues are present as polyglutamates For most conversions polyglutamates will serve as substrates Folate has to be fully reduced to tetrahydrofolate before it can carry a one-carbon unit (Wagner, 1995) The enzyme dihydrofolate reductase reduces folic acid via dihydrofolate to tetrahydrofolate 
Figure 1.2 Schematic overview of the main conversions of the folate one-carbon pool. Modified from Wagner 1995. Folates in this figure are shown as monoglutamates although most folates in human tissues are polyglutamates. The boxes refer to the different folate coenzymes, the italic terms refer to enzymes.

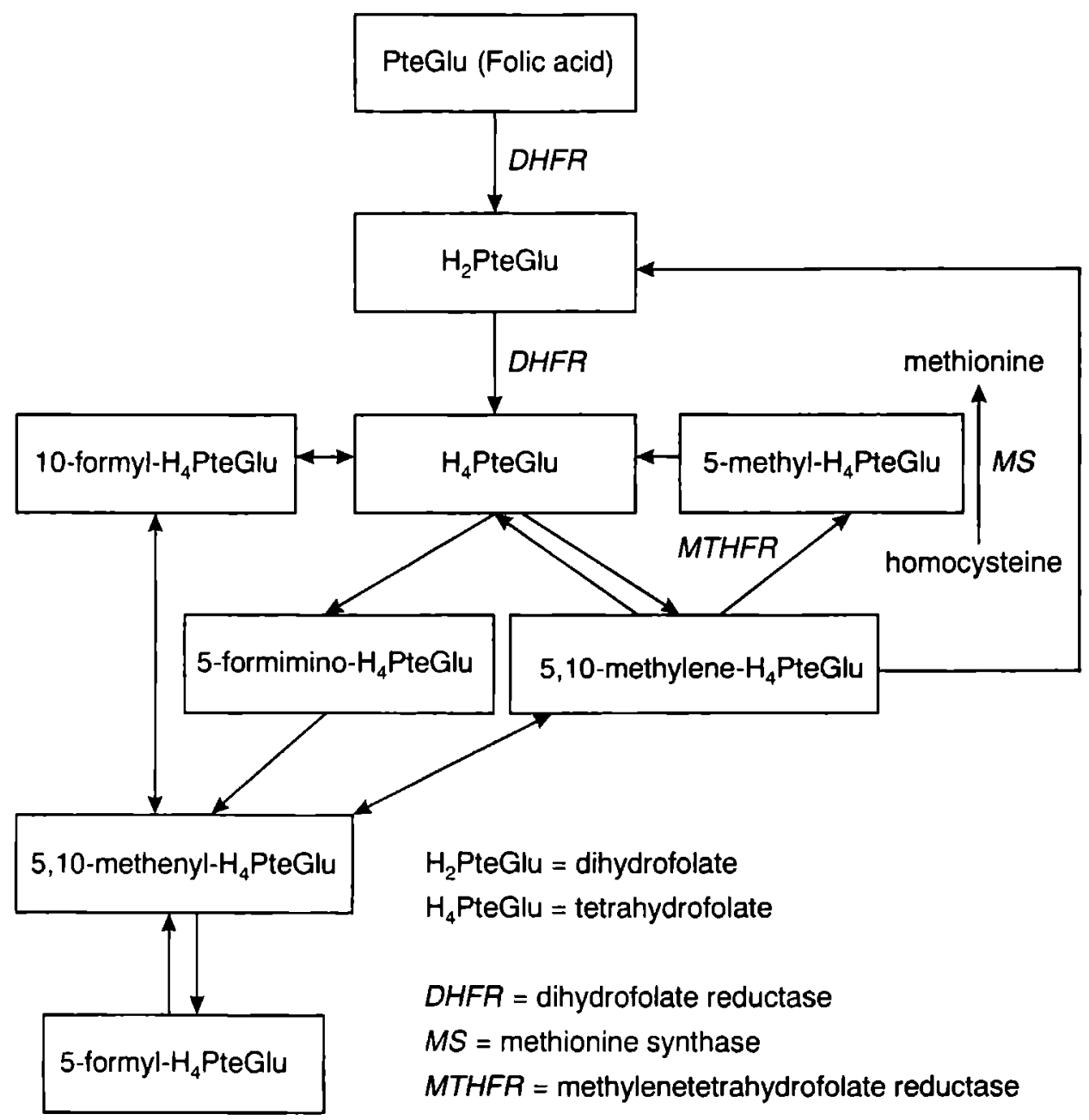


Chapter1

Tetrahydrofolate can via 5,10-methylene-tetrahydrofolate be converted to 5-methyltetrahydrofolate The latter form is a methyl donor for the remethylation of homocysteıne to methıonıne

\section{Intestinal absorption of folate}

Dietary polyglutamyl folates must be deconjugated by the enzyme pteroylpolyglutamate hydrolase (folate conjugase) to a monoglutamyl form before absorption After hydrolysis two different transport systems are present In the first transport system, folates are bound to membrane-associated folate-binding proteins and transported across the brush border membrane by a carrier-mediated mechanısm However, at high intralumınal concentration of folate $(>10 \mu \mathrm{M})$ a nonsaturable diffusıon-mediated transport system plays a major role in folate absorption (Mason, 1990)

Before folic acid enters the portal circulation it is reduced to dihydrofolate and subsequently to tetrahydrofolate, which is either methylated or formylated in the mucosal cells (Perry and Chanarın, 1973, Selhub et al, 1973, Selhub et al, 1983, Strum, 1979) However, at amounts above $266 \mu \mathrm{g}$ of folıc acıd unmetabolised folıc acid has been shown to appear in serum (Kelly et al, 1997)

\section{Bioavailability and bioefficacy of folate}

Folate bıoavallability can be defined as the fraction of folate ingested which may have the potential to meet functional demands in target tissues Homocysteine is a functional parameter of the folate status Therefore, the term bioefficacy can be used if effects on plasma total homocysteıne are used as the determınant of bioavaılabılity (Strain and West, 1999)

\section{Homocysteine metabolism}

Methıonıne is an essential amıno acid that is converted to S-adenosylmethıonıne by methıonıne adenosyltransferase S-adenosylmethıonıne is the main methyl donor S-adenosylhomocysteine is formed after donation of the methyl group S-adenosylhomocysteine is hydrolysed to homocysteine Homocystenne can either be remethylated to methıonıne, or transsulphurated to cysteıne via cystathıonıne Figure 13 shows the main conversions in the homocysteıne metabolism

The enzyme methyltetrahydrofolate-homocysteıne methyltransferase (methıonıne synthase) uses folate, in the 5-methyl-tetrahydrofolate form, as a methyl group donor for the remethylatıon of homocysteıne to methıonıne Vitamın B12 (methylcobalamin) is involved in this remethylation reaction as a co-factor 
Figure 1.3 Schematic view of the main conversions of the homocysteine metabolism.
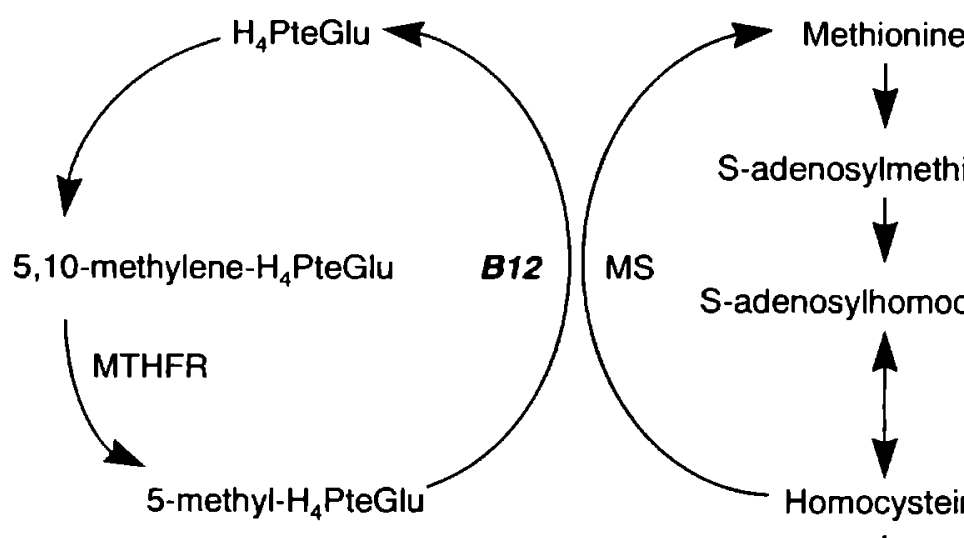

5,10-methylene- $\mathrm{H}_{4}$ PteGlu

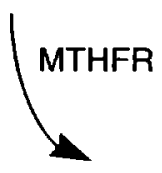

5-methyl- $\mathrm{H}_{4}$ PteGlu

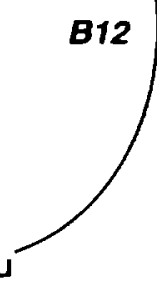

adenosylmethionine
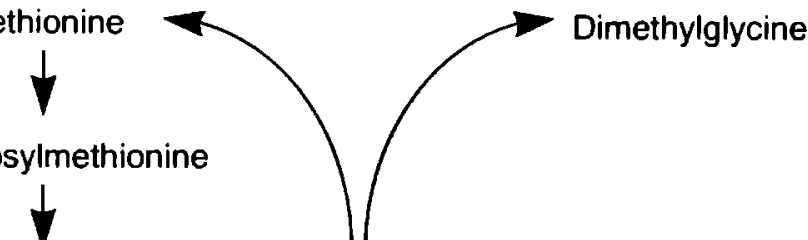

$\mathrm{B} 6=$ vitamin $\mathrm{B} 6$

$\mathrm{B} 12$ = vitamin $\mathrm{B} 12$

BHMT = betaine:homocysteine methyltransferase

$\mathrm{CS}=$ cystathionine synthase

$\mathrm{H}_{4}$ PteGlu = tetrahydrofolate

MS = methionine synthase

MTHFR = methylenetetrahydrofolate reductase

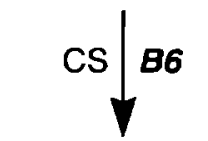

Cystathionine

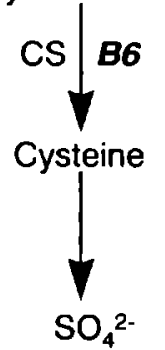


Chapter1

Betaıne-homocysteıne methyltransferase is an enzyme involved in an alternative remethylation pathway Betaine is converted to dimethylglycine and serves as a methyl donor for the remethylation from homocysteıne to methıonine by betaıne-homocysteıne methyltransferase The latter enzyme is mainly found in the Iıver and only minor actıvity has been shown in kıdneys and adrenal glands (Finkelsteın, 1990)

Vitamın B6 is a co-factor in the transsulphuration of homocysteıne to cysteine Homocysteine is first condensed with serıne to form cystathionine by the B6-dependent enzyme cystathionıne $\beta$-synthase This reaction is irreversible Cystathıonine is then further metabolısed to cysteıne by the B6-dependent enzyme $\gamma$-cystathıonase (Ueland et al , 1993)

\section{Consequences of low folate intake}

\section{Neural-tube defects}

Neural-tube defects are one of the most common severe congenital malformations of the central nervous system in man The mean birth prevalence rate of neural-tube defects in the Netherlands is around 14 per 1,000 live births This implies that each year approximately 250 children in the Netherlands are born with a neural-tube defect (EUROCAT Workıng Group, 1998) Neural-tube closure takes place in the third and fourth week after conception Falure of the neural-tube to close results in a neural-tube defect The most common forms of neural-tube defects are spına bifida and anencephaly Spına bifida develops when the neuroporus posterior fails to close The severity of the spina bifida depends on the size of the part of the spınal cord that remains open Menıngomyeloschisıs is an open defect of the spinal cord, whereas spina bifida occulta is a defect by which the skin is closed Anencephaly is a lethal malformation which occurs when the neuroporus anterior remains open and the underdeveloped forebrains remain in contact with the amniotic fluid and subsequently degenerates Menıngocele and menıngo-encephalocele are closed braın defects (Rubın and Farber, 1995)

In 1965, Hibbard and Smıthells were the first to suggest that the B-vitamın folic acid plays a role in the pathogenesis of neural-tube defects (Hibbard and Smithells, 1965) In 1983, Smithells' group showed a $70 \%$ lower neural-tube defect recurrence rate in women who received supplements containing folıc acid (Smithells et al, 1983) However, the study was not randomised and therefore selection bias could not be excluded Two later randomised trials confirmed that supplementation of women with folic acid in the period around conception decreases the occurrence and 
recurrence risk of having offspring with a neural-tube defect (Czeizel and Dudás, 1992; MRC Vitamin Study Research Group, 1991). Governments of several countries responded to the results of these trials by launching advice for women planning to become pregnant (Centers for Disease Control, 1992; Expert Advisory Group, 1992; Food and Nutrition Council, 1992; Food and Nutrition Council, 1993). In the Netherlands, all women planning to become pregnant are advised to take each day a folic acid tablet, containing 400 to $500 \mu \mathrm{g}$ of folic acid in addition to their habitual diet, from at least four weeks before conception up to the eighth week of pregnancy. Women with a history of a neural-tube defect affected pregnancy are advised to take 4-5 mg supplemental folic acid daily (Food and Nutrition Council, 1993). Since January 1998, all fortified flour in the US contains $140 \mathrm{\mu g}$ folic acid per $100 \mathrm{~g}$ by law. This action was taken by the US government to increase the folic acid intake of women in the reproductive age category. These reproductive women are recommended to consume $400 \mu \mathrm{g}$ of synthetic folic acid from fortified foods and/or supplements in addition to intake of folate from a varied diet (Yates et al., 1998). Fortification of the food partly overcomes the problem that women become pregnant without taking extra folic acid in spite of the advice (de Jong-van den Berg et al., 1998).

The underlying mechanism of the preventive effect of folic acid is unclear. Steegers Theunissen et al. noticed a derangement in the homocysteine metabolism in some women with neural-tube defect affected offspring (Steegers Theunissen et al., 1991; Steegers Theunissen et al., 1994). This finding was confirmed by Mills et al. (1995). Folic acid supplementation can decrease plasma total homocysteine concentrations (Chapters 2 and 4 of this thesis; Homocysteine Lowering Trialists' Collaboration). Therefore, homocysteine might play a role in the aetiology of neuraltube defects.

\section{Cardiovascular disease}

Cardiovascular diseases are a major health problem in the Western world. In the Netherlands, they are responsible for approximately $40 \%$ of total mortality (Dutch Heart Foundation, 1997). Several studies have shown that patients with cardiovascular diseases have higher plasma total homocysteine concentrations than healthy control subjects (Boushey et al., 1995; Clarke et al., 1991; den Heijer et al., 1996; Falcon et al., 1994; Pancharuniti et al., 1994; Selhub et al., 1995; Stampfer et al., 1992). Boushey et al. (1995) estimated that a total of $10 \%$ of the population's risk for coronary artery disease is attributable to elevated plasma total homocysteine concentrations. Furthermore, the relationship between the plasma total homocysteine concentration and cardiovascular disease seems to be continuous 
with no apparent threshold (Refsum et al., 1998). The European Concerted Action Project showed that an increased plasma total homocysteine concentration conferred not only an independent risk of cardiovascular disease, but the risk increased strongly in combination with smoking and hypertension (Graham et al., 1997). Moreover, a low folate intake has also been shown to be a risk factor for cardiovascular disease (Giles et al., 1995; Morrison et al., 1996; Pancharuniti et al., 1994; Selhub et al., 1995). Intakes of doses of folic acid above $650 \mu \mathrm{g}$ per day have been shown to decrease plasma total homocysteine concentrations which may decrease the risk of cardiovascular disease (Ubbink, 1997). Intervention studies are currently running to investigate whether homocysteine-lowering therapies indeed lead to a decrease in cardiovascular disease.

\section{Study designs}

Several strategies can be used to investigate the relationship between folate and folic acid intake and folate and homocysteine concentrations in the blood. Different strategies can be distinguished by differences in study design. Firstly, in observational studies subjects are studied without intervening in their dietary habits or lifestyle. This implies that the burden on the subjects and the costs of these studies are relatively low. On the other hand, selection bias and possible confounding are more difficult to control than in intervention studies. De Bree et al. summarised studies investigating habitual folate intake of adult populations in Europe (de Bree et al., 1997). In this thesis we studied the relationship between intake and status using intervention studies.

Intervention studies actively interfere in lifestyle and usual customs of subjects. The ideal design of an intervention study is a cross-over, placebocontrolled randomised trial. In a cross-over study all subjects receive both placebo and intervention treatment in random order. If necessary, a wash-out period should be taken in between two treatments. Studies investigating a longer period of intervention with folic acid or folate have to take into account that the washout period after treatment with folic acid should be at least four months (see Chapter 2). This implies that cross-over studies are time-consuming, which increases the chance that subjects withdraw from the study. Therefore, parallel designs have been used in most studies investigating the effects of supplementation with folic acid or folate on folate and homocysteine status. In a parallel design, groups of subjects receive different treatments at the same time. All studies described in this thesis have a parallel design. 
To ensure that the observed effects are caused by the treatment and not by other factors, a placebo group should be included. The placebo group needs to be treated in the same way as the intervention groups, but has to receive placebo treatment instead of the chosen intervention treatment. Therefore, changes irrespective of treatment, such as random drifts with time, will also occur in the placebo group. Studies described in Chapters 2, 3 and 6 include a placebo group. An alternative for a placebo group, in case the number of subjects is limited, is a sequential design with a placebo period followed by an intervention period (see Chapter 5 ). In such a design subjects receive first placebo treatment followed by intervention treatment. The change in the treatment period can then be corrected for the change in the placebo period. The main disadvantage of this design is that period effects cannot be excluded. A placebo group can be omitted for efficiency reasons if the effect of one of the intervention strategies is already established (see Chapter 4). However, inclusion of a placebo group is preferred.

Subjects should always be randomly divided into the groups to prevent selection bias. This implies that neither subjects nor researchers can choose who will be assigned to which group. To prevent differences in baseline values among intervention groups, researchers can choose to stratify for these values and randomise after stratification (see Chapter 6).

Studies should be of a blind nature to prevent subjects influencing the response to their treatment. In intervention studies with folic acid, tablets or fortified products can be manufactured in such a manner that the treatments are indistinguishable. However, in intervention studies using natural food folate it is not possible to mask the differences between dietary treatments (Cuskelly et al. 1996; Chapter 6).

Another important factor in intervention studies is the measure of control. The least controlled situation is a study in which subjects are merely advised to change their normal habits, for example to take tablets or to eat different products. This strategy can be used to test whether an advice given by a government can be effective or not (see Cuskelly et al. 1996). To enlarge the chance that subjects will indeed change their habits, supplements can be given to them. This is more convenient for the subjects and therefore compliance will be better. Folic acid and placebo tablets were therefore provided in the studies described in Chapters 2, 3, 4 and 5, as in many other studies (Homocysteine Lowering Trialists' Collaboration, 1998). Some studies provided foods fortified with folic acid (Malinow et al., 1998; Schorah et al., 1998). Cuskelly et al. (1996) provided products naturally rich in folate to their dietary folate group. The advantage of advising subjects or supplying 
supplemental items is that it can easily be implemented in the free-living situation. However, when no effect is observed it is not clear whether this is caused by lack of compliance of the subjects or because the intervention treatment is not effective. To diminish the risk of non-compliance, intake should be checked. Compliance can be checked by counting the remaining tablets, examining tablet calendars or diaries (Chapters 2, 3, 4 and 5), assessment of concentrations in blood or tissues, and assessment of dietary intake by a validated method (see Cuskelly et al. 1996; Chapters 2 and 3 ).

To increase compliance even further, investigators may choose to perform a completely controlled study, in which the investigators supply the full diet and supervise the subjects. In the most controlled setting, subjects are living in a metabolic ward, under supervision, 24 hours per day (Jacob et al., 1995; Jacob et al., 1994; Sauberlich et al., 1987). The investigators know exactly what the subjects consumed during the study. However, the burden on the subjects is high and such studies usually involve a limited number of subjects. Supplying a complete diet to subjects, but not trying to control their daily activities (Chapter 6 ) can reduce these disadvantages. Deviations from the protocol occur more frequently in a setting in which only the diet is controlled compared to a completely controlled trial, but are still considerably less in studies where only supplements to the diets are supplied. By supervising one or more meals per day subjects have even less chance to deviate from the protocol (Chapter 6). All strictly controlled trials have the disadvantage that they do not investigate whether these strategies can be implemented in normal life.

The choice of study design should mainly depend on the research question, although practical limitations play a role as well. 


\section{Outline of the thesis}

Supplementation with high doses of folic acid is known to decrease plasma total homocysteine concentrations and to improve the folate status in healthy men and women. Investigating the effects of natural food folate on the folate and homocysteine metabolism is a complicated task. Therefore, it is important to first know whether low doses of supplemental folic acid can decrease plasma total homocysteine concentrations and improve the folate status in healthy subjects (objective 1). Chapter 2 answers the question whether supplementation with low doses of folic acid (250 - $500 \mu \mathrm{g}$ per day) decreases plasma total homocysteine and improves the folate status in healthy volunteers. This chapter also describes whether eight weeks of washout is sufficient for the subjects to return to baseline concentrations of blood folate and plasma total homocysteine.

A decrease of plasma total homocysteine concentrations by folic acid supplementation would theoretically lead to an increase in methionine concentrations because folate is a methyl donor in the remethylation reaction of homocysteine to methionine. Chapter 3 reports whether folic acid supplementation indeed leads to increased plasma methionine concentrations.

One group described in Chapters 2 and 3 received a tablet containing $500 \mu \mathrm{g}$ of folic acid and a placebo tablet on alternate days. Therefore, Chapter 4 describes a study investigating whether providing subjects with $500 \mu \mathrm{g}$ of folic acid every other day leads to effects on folate status and plasma total homocysteine concentrations that differ from those of providing subjects with $250 \mu \mathrm{g}$ of folic acid every day.

Chapter 5 describes a case-control study in patients with spina bifida and disabled control subjects. We investigated their homocysteine and folate status at baseline. Furthermore, we studied the impact of folic acid supplementation on the folate status and homocysteine concentrations of the spina bifida patients and the control subjects (objective 2).

The effects of a folate rich diet on folate status and homocysteine concentrations are largely unknown. Therefore, Chapter 6 reports results of a dietary controlled intervention study. The study investigated whether natural food folate from vegetables and citrus fruit would improve the folate status and decrease plasma total homocysteine concentrations (objective 3 ).

Chapter 7 reviews the literature investigating the many factors that may influence folate bioavallability and bioefficacy. 
Chapter1

Chapter 8 discusses the main conclusions and implications of the studies described in this thesis. 


\section{Low-dose folic acid supplementation decreases plasma homocysteine: a randomized trial}

Ingeborg A Brouwer, Marijke van Dusseldorp, Chris MG Thomas, Marinus Duran, Joseph GAJ Hautvast, Tom KAB Eskes, Régine PM Steegers Theunissen.

The American Journal of Clinical Nutrition 1999; 69: 99-104. 


\section{Abstract}

Background: An elevated plasma total homocysteine concentration is a risk factor for cardiovascular disease and neural-tube defects A high daly intake of supplemental folic acid is known to decrease total homocysteıne concentrations

Objective: We studied the effect of low-dose folic acid administration (250 or 500 $\mu \mathrm{g} / \mathrm{d})$ for four weeks on plasma total homocysteıne concentrations and folate status We also investigated whether total homocysteine concentrations and blood folate concentrations returned to baselıne after an eight-week washout perıod

Design: In this placebo-controlled study 144 healthy women aged 18-40 years received $500 \mu \mathrm{g}$ folic acıd/d, $500 \mu \mathrm{g}$ folıc acıd every second day $(250 \mu \mathrm{g} / \mathrm{d})$, or a placebo tablet with their habitual diet (mean dietary folate intake $280 \mu \mathrm{g} / \mathrm{d}$ )

Results: Administration of 250 and $500 \mu \mathrm{g}$ folic acid/d for 4 weeks significantly increased folate concentrations in plasma $(P<0001)$ and red cells $(P<001)$ Total homocysteıne concentrations decreased significantly $(P<0001)$ in women $(n=50)$ who took $250 \mu \mathrm{g}$ folic acid/d [mean ( \pm SEM) deviation from baseline $-114 \pm 198 \%$ ] and in women $(n=45)$ who took $500 \mu \mathrm{g}$ folic acid/d (-21 $8 \pm 149 \%)$ Eight weeks after the end of the intervention period (week 12), plasma total homocysteine concentrations in the folic acid-supplemented groups had not returned to baseline (week 0)

Conclusions: Doses of folic acid as low as $250 \mu \mathrm{g} / \mathrm{d}$, on average, in addition to the usual dietary intakes, significantly decreased plasma total homocysteine concentrations in healthy, young women An eight-weeks washout period was not sufficient for blood folate and plasma total homocysteine concentrations to return to baseline concentrations 


\section{Introduction}

Folic acid has received a great deal of attention because of its role in the prevention of neural-tube defects. Sufficient evidence is now available to advise women to increase their folic acid intake if they are planning to become pregnant (Czeizel and Dudás, 1992; MRC Vitamin Study Research Group, 1991). Doses of supplemental folic acid between 360 and $4000 \mu \mathrm{g} / \mathrm{d}$ in addition to usual dietary intakes of folate have been proven to prevent neural-tube defects (Czeizel and Dudás, 1992; Kirke et al., 1992; Laurence et al., 1981; MRC Vitamin Study Research Group, 1991; Smithells et al., 1983).

Folate is an important substrate in the remethylation of homocysteine to methionine. Steegers Theunissen et al. showed that a subgroup of women who had previously experienced an neural-tube defect affected pregnancy had higher plasma total homocysteine concentrations than healthy control women (Steegers Theunissen et al., 1994). A mildy elevated plasma total homocysteine concentration is suggested to be a marker for a defect in folate metabolism or for folate deficiency and is thus a risk factor for having a child with a neural-tube defect (Mills et al., 1995; Steegers Theunissen et al., 1994).

High plasma total homocysteine concentrations are also considered a risk factor for cardiovascular disease. The prevalence of elevated plasma total homocysteine concentrations is higher in patients with coronary artery disease (Pancharuniti et al., 1994; Stampfer et al., 1992), cerebrovascular (Clarke et al., 1991; Selhub et al., 1995) and peripheral vascular diseases and thrombosis (den Heijer et al., 1996; Falcon et al., 1994) than in healthy control subjects. Evidence is accumulating that folate is involved in the prevention of these diseases. Low folate concentrations in blood are associated with cardiovascular disease (Giles et al., 1995; Morrison et al., 1996; Pancharuniti et al., 1994; Selhub et al., 1995) and folate intake is related to carotid artery stenosis (Selhub et al., 1995).

Intakes of supplemental folic acid $\geq 650 \mu \mathrm{g} / \mathrm{d}$ are known to decrease plasma total homocysteine concentrations (Ubbink, 1997). Some studies have investigated the effect of low doses of supplemental folic acid on plasma total homocysteine concentrations (den Heijer et al., 1998; Guttormsen et al., 1996a; Jacob et al., 1994; O'Keefe et al., 1995; Ward et al., 1997). However, this is the first placebo-controlled, in-depth study of the effects of supplemental folic acid (as low as $500 \mu \mathrm{g}$ every other day) on plasma total homocysteine concentrations in healthy subjects with normal plasma total homocysteine concentrations. If low doses of supplemental folic acid also decrease plasma total homocysteine concentrations, then intervention with foods rich in folate could also be an option to reduce plasma total homocysteine.

Therefore, the aim of the present study was to investigate whether an average daily intake of 250 or $500 \mu \mathrm{g}$ of supplemental folic acid decreases plasma total 
homocysteine concentrations in healthy women. In addition, we investigated whether plasma total homocysteine concentrations returned to baseline (week 0 ) within eight weeks after the intervention ended (week 12) and how these treatments affected plasma and red blood cell folate concentrations.

\section{Subjects and Methods}

\section{Subjects}

Healthy, nonpregnant women aged $18-40$ years were recruited by advertisements in local newspapers and by the distribution of leaflets. Women were excluded if they were smokers, had a gastrointestinal disorder, or had used any of the following preparations during the two months preceding the trial: vitamins, minerals, yeast or seaweed, malaria prophylaxis, or anticonvulsants. On the basis of these criteria 158 women were eligible for participation. After recruitment, seven women withdrew, five were excluded because they could not attend the first blood collection session, and two because they were already participating in another nutritional study. The final study group consisted of 144 women.

The study design was approved by the Medical Ethical Committee of the Wageningen Agricultural University. All subjects gave written informed consent. The fieldwork of the study was performed at the Division of Human Nutrition and Epidemiology of the Wageningen Agricultural University.

\section{Methods}

After stratification by the use and type (brand) of oral contraceptives used, the women were divided at random (by alternation) into three intervention groups: 500 $\mu \mathrm{g}$ folic acid/d (500- $\mu \mathrm{g}$ group), $500 \mu \mathrm{g}$ folic acid every other day (on average 250 $\mu \mathrm{g} / \mathrm{d} ; 250-\mu \mathrm{g}$ group), or a placebo (placebo group) for four weeks. To maintain the blind nature of the study, all subjects received two containers of tablets, one marked with a red sticker and one with a yellow sticker. The tablets were indistinguishable from each other in appearance and taste.

Subjects received a diary and a calendar in which the days were alternately marked red and yellow. Subjects were asked to maintain their regular diet, but to refrain from consuming liver and marmite, a yeast extract. All subjects kept a diary in which they reported the intake of tablets, illnesses experienced, the days on which they menstruated, the days on which they did not take oral contraceptives, any extraordinary foods consumed, and excessive physical activity. To assess compliance, we counted any remaining tablets and checked the reported intake of tablets in the diaries. On the days blood was collected, subjects took their tablets after blood sampling. Tablets were always taken before breakfast. A 24-hour recall was obtained from each subject once during the intervention period to check their intake of macronutrients and folate.

Venous blood samples were collected after subjects had fasted overnight 
beginning at the start of the four-weeks intervention period (week 0), after 1, 2 and 4 weeks of intervention (weeks 1,2 and 4) and 4 and 8 weeks after the intervention perıod ended (weeks 8 and 12) Total plasma homocysteıne and plasma folate concentratıons were determined in all blood samples Red blood cell folate concentrations were assessed at baseline (week 0 ) and at the end of both the intervention (week 4) and washout perıods (week 12) We determıned plasma vitamın B12 concentrations at the start of the intervention period

Blood samples were drawn into EDTA-containıng evacuated tubes Venoject II, Terumo, Madrid, Spain) For the determınation of plasma total homocysteine, plasma folate and plasma vitamın B12, samples were immediately placed on ice and centrifuged withın $60 \mathrm{~m} ı \mathrm{n}$ at $3000 \mathrm{xg}$ for $10 \mathrm{~min}$ at $4^{\circ} \mathrm{C}$ Plasma was separated and stored at $-35^{\circ} \mathrm{C}$ for folate and vitamın $\mathrm{B} 12$ and at $-80^{\circ} \mathrm{C}$ for plasma total homocysteıne determınation For the determınatıon of folate concentrations in red blood cells, haematocrit samples were analysed and a 14 dilution of whole blood was stored in sodium ascorbate $(10 \mathrm{~g} / \mathrm{L})$ at $-35^{\circ} \mathrm{C}$ The hemolysates were further diluted with IMx Folate RBC Lysıs Reagent (Abbott Diagnostıcs, Maidenhead, United Kıngdom) before measurement Total homocysteıne concentrations were measured by HPLC technique and fluorimetric detection (intra- and inter-assay CVs $<8 \%$ ) (Arakı and Sako, 1987) All samples from each subject were analysed in the same run Folate concentrations in plasma and red blood cells and vitamın B12 in plasma were determıned with the IMx automated ımmunoassay system (Abbott Laboratories, North Chıcago), the vitamın B12 assays is based on microparticle technology (micropartıcle intrinsıc factor assay) and the plasma and red blood cell folate assays are based on ion-capture technology The intra-assay $\mathrm{CV}$ of the folate assay varied between $3 \%$ and $6 \%$, whereas the inter-assay CV varied between $6 \%$ and $10 \%$, depending on the folate concentration For vitamın B12, both the intra- and interassay CVs were $<5 \%$

\section{Statistical analyses}

The response to the various treatments was calculated for each subject as the change in plasma total homocystenne, plasma folate, or red blood cell folate, between the start (week 0) and the end (week 4) of the intervention period Estımation of group sızes was based on a $10 \%$ decrease in plasma total homocysteıne concentrations after four weeks of supplementation with $400 \mu \mathrm{g}$ folic acid in young women in Germany (Dierkes, 1995) On the basis of these data, 50 women per group would be sufficient to detect a change in plasma total homocysteine of $1 \mu \mathrm{mol} / \mathrm{L}$ with a power of $90 \%$ and an $\alpha$ of 005 Furthermore, changes in plasma total homocysteıne and plasma and red blood cell folate were calculated per subject between the start of the intervention period and the end of the washout period (week 0 - week 12) The changes in folate and plasma total homocysteıne concentrations were normally distributed One-way analysis of variance was used to analyse differences in responses of and in baseline concentrations of plasma total homocysteıne, folate and vitamın B12 among the 
Chapter 2

three groups When this analysis indicated a significant difference $(P<0$ 05) multiple comparisons were made by Student's $t$ tests, using a significance level of $P<005 / 3$ $=0017$ (to maintain an overall significance level of $P<005$ )

\section{Results}

There were no significant differences among the three groups with respect to age, body mass index, use of oral contraceptives, or baselıne concentrations of vitamın B12, plasma and red blood cell folate (Table 2 1) Although the subjects had been randomly assıgned ınto the three groups, the baselıne concentratıons of plasma total homocysteıne differed significantly among the groups The mean dietary intakes of folate and macronutrients during the intervention period did not differ significantly among the three intervention groups

Subject compliance was determıned to be good on the basis of tablet counts and diaries Twenty-three subjects forgot to take one tablet during the whole study period and only five subjects forgot to take two tablets

After four weeks of intervention, plasma and red blood cell folate concentrations had increased significantly in the two treatment groups compared to the placebo group (Table 2 2) The increases in plasma folate were sıgnificantly higher in the $500-\mu g$ group than in the $250-\mu g$ group $(P<0001)$ During the eight weeks after the end of the intervention period, the so-called washout period, plasma folate concentrations decreased significantly in the two treatment groups compared to the placebo group However, the plasma folate concentration between weeks 0 and 12 was stıll significantly higher in the two treatment groups than in the placebo group $(P<001)$ Red blood cell folate concentrations remained stable during the washout period

Total homocysteine concentrations decreased during the four-weeks intervention period in the two treatment groups, whereas they remained stable in the placebo group (Figure 2 1) Four weeks of supplementation with $500 \mu \mathrm{gg}$ folic acid every other day resulted in a decrease in the plasma total homocysteine concentrations of $114 \%$ compared to $08 \%$ in the placebo group (Figure 21 ) In the $500-\mu \mathrm{g}$ group, plasma total homocysteine decreased $218 \%$ No significant changes occurred in plasma total homocysteıne concentrations between weeks 4 and 12 (during the washout period) At the end of the washout period, plasma total homocysteine concentrations in the two treatment groups were still significantly lower than those in the placebo group

The quintıles of subjects with the highest baselıne plasma total homocysteine concentrations showed the most pronounced decrease in plasma total homocysteıne (Figure 2 2) 
Table 2.1 Characteristics of the study population of 144 healthy women (18-40 years)

\begin{tabular}{|c|c|c|c|}
\hline & $\begin{array}{c}500 \mu g / d \text { group } \\
(n=45)\end{array}$ & $\begin{array}{c}250 \mu \mathrm{g} / \mathrm{d} \text { group } \\
(n=50)\end{array}$ & $\begin{array}{l}\text { placebo group } \\
\qquad(n=49)\end{array}$ \\
\hline Age (years) & $236 \pm 41$ & $217 \pm 20$ & $223 \pm 31$ \\
\hline $\mathrm{BMI}\left(\mathrm{kg} / \mathrm{m}^{2}\right)$ & $223 \pm 25$ & $228 \pm 28$ & $221 \pm 23$ \\
\hline Use of OC (\%) & 71 & 66 & 65 \\
\hline Homocysteıne $(\mu \mathrm{mol} / \mathrm{L})^{2}$ & $111 \pm 26^{\prime}$ & $97 \pm 22$ & $104 \pm 25$ \\
\hline Plasma folate $(\mathrm{nmol} / \mathrm{L})$ & $113 \pm 43$ & $114 \pm 34$ & $120 \pm 42$ \\
\hline RBC folate (nmol/L) & $400 \pm 107$ & $386 \pm 85$ & $422 \pm 181$ \\
\hline Vitamın B12 (pmol/L) & $265 \pm 117$ & $290 \pm 88$ & $286 \pm 110$ \\
\hline Folate intake $(\mu \mathrm{g} / \mathrm{d})^{3}$ & $290 \pm 100$ & $175 \pm 99$ & $277 \pm 111$ \\
\hline Energy Intake (MJ/d) & $89 \pm 20$ & $95 \pm 25$ & $97 \pm 32$ \\
\hline Protein Intake (En\%) & $160 \pm 36$ & $147 \pm 30$ & $153 \pm 32$ \\
\hline Fat intake (En\%) & $332 \pm 71$ & $334 \pm 86$ & $340 \pm 64$ \\
\hline CHO intake (En\%) & $510 \pm 66$ & $512 \pm 87$ & $498 \pm 74$ \\
\hline
\end{tabular}

$B M I$, body mass index OC, oral contraceptives RBC, red blood cell $\mathrm{CHO}$, carbohydrate En\%, percentage energy

Values are expressed as means \pm SD

' Significant difference from $250 \mu \mathrm{g}$ group (t-test) $P<001^{2}$ Significant difference between three groups (ANOVA) $P<005^{3}$ 24-hour recalls were obtained once from each subject during the intervention period 
Table 2.2 Plasma folate and red blood cell folate concentrations during and after four weeks of folic acid supplementation, and at 4 (week 8) and 8 weeks (week 12) after the end of the intervention period.'

\begin{tabular}{|c|c|c|c|}
\hline & $\begin{array}{c}500 \mu \mathrm{g} / \mathrm{d} \text { group } \\
(n=45)\end{array}$ & $\begin{array}{c}250 \mu g / d \text { group } \\
(n=50)\end{array}$ & $\begin{array}{l}\text { placebo group } \\
\qquad(n=49)\end{array}$ \\
\hline & \multicolumn{3}{|c|}{ Plasma folate (nmol/L) } \\
\hline Week 0 & $11 \pm 4.0$ & $11 \pm 3.4$ & $12 \pm 4.2$ \\
\hline Week 1 & $21 \pm 7.0$ & $19 \pm 6.2$ & $16 \pm 6.0$ \\
\hline Week 2 & $21 \pm 6.5$ & $18 \pm 5.4$ & $14 \pm 4.8$ \\
\hline Week 4 & $27 \pm 5.1$ & $23 \pm 5.3$ & $17 \pm 6.1$ \\
\hline Week 4 - 0 & $16.1(14.8,17.4)^{a . b}$ & $11.3(9.8,12.8)^{\mathrm{a}}$ & $5.2(3.8,6.6)$ \\
\hline Week 8 & $22 \pm 5.2$ & $20 \pm 4.7$ & $16 \pm 5.3$ \\
\hline Week 12 & $21 \pm 4.6$ & $21 \pm 5.1$ & $18 \pm 5.0$ \\
\hline \multirow[t]{2}{*}{ Week 12 - 0} & $9.9(8.6,11.2)^{a}$ & $9.1(7.6,10.5)^{c}$ & $6.4(5.1,7.7)$ \\
\hline & \multicolumn{3}{|c|}{ Red blood cell folate (nmol/L) } \\
\hline Week 0 & $400 \pm 107$ & $386 \pm 85$ & $422 \pm 181$ \\
\hline Week 4 & $508 \pm 176$ & $432 \pm 126$ & $401 \pm 182$ \\
\hline Week 4 - 0 & $93(65,121)^{a}$ & $47(11,83)^{c}$ & $-17.3(-37.5,2.9)$ \\
\hline Week 12 & $500 \pm 152$ & $433 \pm 99$ & $402 \pm 152$ \\
\hline Week $12-0$ & $91(65,118)^{a}$ & $45(17,74)^{c}$ & $-14.0(-35.3,7.2)$ \\
\hline
\end{tabular}

'Absolute values are presented as means \pm SD. Changes from week 0 to 4 and from week 0 to 12 are given as means $(95 \% \mathrm{Cl})$. Changes were normally distributed, absolute values not.

a Significant difference with placebo group, $P<0.001$.

- Significant difference with $250 \mu \mathrm{g}$ group, $P<0.001$.

' Significant difference with placebo group, $P<0.01$. 
Figure 2.1 Mean plasma total homocysteine (tHcy) levels and extent of deviation from baseline (percent change \pm SEM) during 4 weeks of folic acid supplementation and 4 and 8 weeks after the end of the intervention period in 144 healthy, nonpregnant women (18-40 years)'.
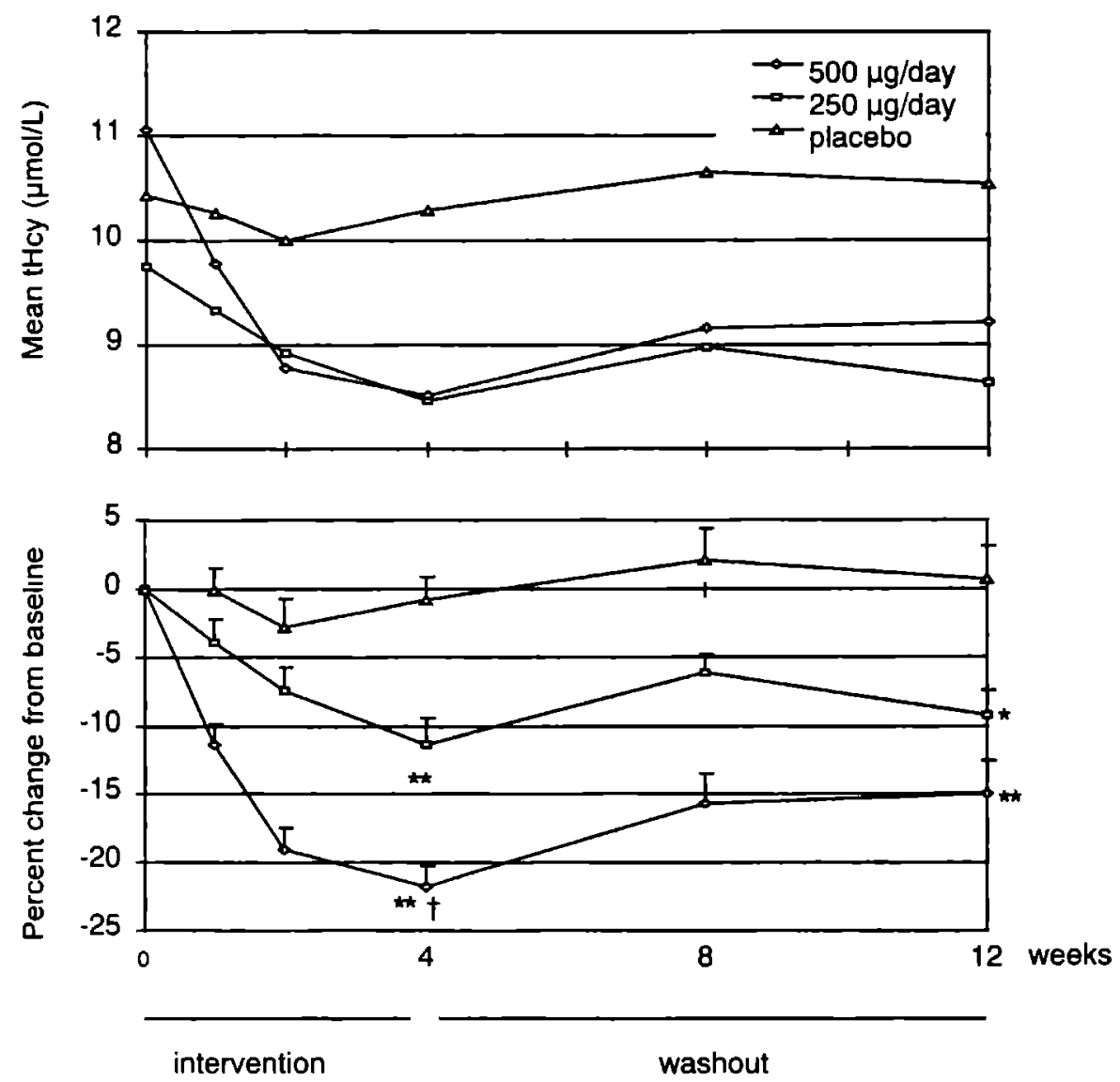

\section{Footnote by Figure 2.1:}

${ }^{1}$ Differences only tested at weeks 4 and 12. The extent of deviation from week 0 to 4 and from week 0 to 12 was significantly different between the three groups (ANOVA): $P<0.001$.

* Significant difference between intervention group and placebo group $(P<0.01)$. * Significant difference between intervention group and placebo group $(P<0.001)$. $\dagger$ Significant difference between $500 \mu \mathrm{g} / \mathrm{d}$ group and $250 \mu \mathrm{g} / \mathrm{d}$ group $(P<0.001)$. 
Chapter 2

Figure 2.2 The mean change (lower $95 \% \mathrm{Cl}$ limit) in plasma total homocysteine (tHcy) concentrations ( $\mu \mathrm{mol} / \mathrm{L}$ ) after four weeks of folic acid supplementation by quintiles of baseline tHcy concentrations for each intervention group in 144 healthy, non-pregnant women (18-40 yrs).

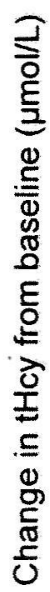

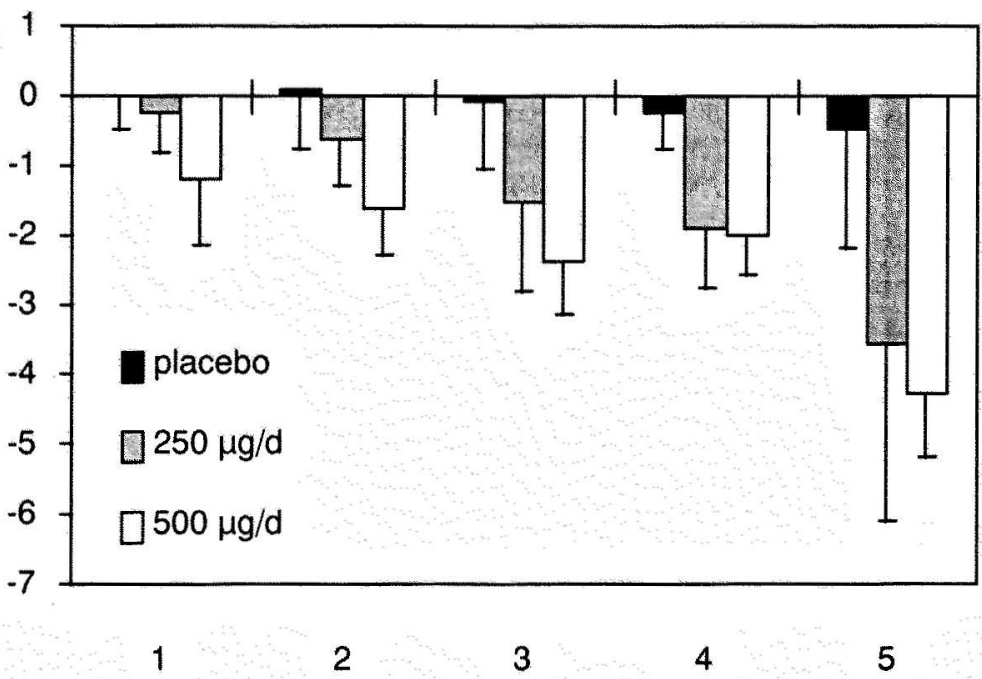

Quintiles of baseline tHcy

\section{Footnote by Figure 2.2:}

Mean $( \pm S D)$ baseline tHcy concentrations $(\mu \mathrm{mol} / \mathrm{L})$ per quintile:

Quintile 1: $7.5 \pm 0.7 \mu \mathrm{mol} / \mathrm{L}$

(placebo $n=8,250 \mu \mathrm{g} /$ day $n=12,500 \mu \mathrm{g} /$ day $n=7$ )

Quintile 2: $8.9 \pm 0.3 \mu \mathrm{mol} / \mathrm{L}$

(placebo $n=8,250 \mu \mathrm{g} /$ day $n=14,500 \mu \mathrm{g} /$ day $n=8$ )

Quintile 3: $9.9 \pm 0.4 \mu \mathrm{mol} / \mathrm{L}$

(placebo $n=15,250 \mu \mathrm{g} /$ day $n=6,500 \mu \mathrm{g} /$ day $n=8$ )

Quintile 4: $11.5 \pm 0.5 \mu \mathrm{mol} / \mathrm{L}$

(placebo $n=10,250 \mu \mathrm{g} /$ day $n=11,500 \mu \mathrm{g} /$ day $n=9$ )

Quintile 5: $14.3 \pm 1.9 \mu \mathrm{mol} / \mathrm{L}$

(placebo $n=8,250 \mu \mathrm{g} /$ day $n=5,500 \mu \mathrm{g} /$ day $n=13$ ) 


\section{Discussion}

\section{Intervention period}

The present study clearly showed that four weeks of folic acid supplementation with a daily dose of $500 \mu \mathrm{g}$ or $500 \mu \mathrm{gg}$ every second day rapidly and significantly increased plasma and red blood cell folate concentrations and significantly decreased plasma total homocysteine concentrations. Supplementation with $500 \mu g$ folic acid/d caused the most distinct decrease in plasma total homocysteine concentrations in the first two weeks of intervention (Figure 2.1). Assuming that plasma total homocysteine is a valid functional index of folate status (Stites et al., 1997; Ubbink et al., 1994), these results showed that the recommended period of folic acid use of four weeks before conception is sufficient to improve folate status. Neural-tube closure takes place during the third and fourth weeks of pregnancy. Our results suggest that even if women did not take folic acid before pregnancy, for example in the case of an unplanned pregnancy, it might still be worthwhile to start taking extra folic acid immediately after missing the first menstrual period because plasma total homocysteine and folate status improved after as little as one week of supplementation.

The extent of the decrease in plasma total homocysteine was influenced by the initial plasma total homocysteine concentrations of the study subjects (Figure 2.2). Subjects in the fifth quintile of initial plasma total homocysteine concentrations showed a much greater decrease in plasma total homocysteine concentration after intervention with folic acid than did subjects with low initial plasma total homocysteine concentrations. This could not have been due to regression towards the mean because the placebo group did not show this phenomenon. These findings agree with the results of Ward et al. (1997). This also explains the discrepancy with the results of Ubbink et al. who showed a $42 \%$ decrease in plasma total homocysteine concentrations after six weeks of supplementation with $650 \mu \mathrm{g}$ folic acid/d (Ubbink et al., 1994). Their study population was men with hyperhomocysteinemia (mean \pm SD: $28.8 \pm 14.5 \mu \mathrm{mol} / \mathrm{L}$ ), whereas our subjects had normal plasma total homocysteine concentrations, with a mean baseline concentration of $10.5 \mu \mathrm{mol} / \mathrm{L}$ (Ubbink et al., 1994).

Despite random allocation of the treatments, the mean baseline homocysteine

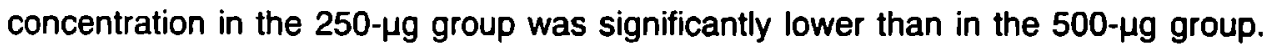
These differences may have occurred by chance. They cannot be explained by differences in folate and vitamin B12 concentrations because they were comparable in all three groups (Table 2.1).

During the four weeks of intervention, plasma total homocysteine concentrations gradually decreased in women in the $250-\mu \mathrm{g}$ group (Figure 2.1). In contrast, during the first two weeks of intervention the decrease in the $500-\mu \mathrm{g}$ group was more or less linear, whereas in the subsequent two weeks the decrease was more gradual. An explanation may be that the plasma total homocysteine 
concentrations of many subjects in the $500-\mu \mathrm{g}$ group had already plateaued between the second and fourth week of supplementation, whereas four weeks of intervention with $250 \mu \mathrm{g} / \mathrm{d}$ was not sufficient to have this effect Several studies suggest that a high dose of folic acid will have no additional plasma total homocysteine-lowering effect after a plateau has been reached However, the lowest effective folate intake and the optımal duration of supplementation are not clear The results depicted in Figure 22 suggest that, at least over a four-weeks intervention period, $500 \mu \mathrm{g} / \mathrm{d}$ has a more pronounced effect on plasma total homocysteine concentrations than does $250 \mu \mathrm{g} / \mathrm{d}$

\section{Washout period}

Eight weeks after the end of the supplementation perıod, plasma total homocysteine concentrations had not returned to baseline Although plasma folate concentrations In the 250- and 500- $\mu \mathrm{g}$ groups decreased after supplementation had ceased, concentrations remained higher than those in the placebo group throughout the study period This was not unexpected because the whole-body folate pool has a slow turnover of $<1 \% / d$ (Stites et al, 1997) Therefore, plasma total homocysteine was expected to remain lower and blood folate concentrations were expected to remain higher than at the start of the study for more than three months

Red blood cell folate concentrations did not change between the end of the intervention period and the end of the study (Table 22 ) This finding agrees with the suggestion that red blood cells incorporate folate at erythropoiesis (Shane, 1995, Zettner et al , 1981) and retain it during their whole life-span (Shane, 1995)

Data suggest that lowerıng plasma total homocysteıne may have important implications for the prevention of cardiovascular diseases in the general population Boushey et al (1995) estımated that an increment in plasma total homocysteine of 5 $\mu \mathrm{mol} / \mathrm{L}$ would result in an increase in the relative risk to 14 However, studies in which plasma total homocysteine-lowering therapy, for example, by folic acid supplementation, resulted in a reduction in the incidence of cardiovascular disease have not yet been reported

Our results indicate that 4 weeks of folic acid supplementation with an average dally dose of 250 or $500 \mu \mathrm{g}$ decreases plasma total homocystenne by $11 \%$ and $22 \%$ ( 13 and $26 \mu \mathrm{mol} / \mathrm{L}$ ), respectively In this study we supplied the $250-\mu \mathrm{g}$ group with $500 \mu \mathrm{g}$ every other day We thınk that this might have underestimated the effect in the 250- $\mu$ group, because Kelly et al (1997) showed that intake of $>266 \mu \mathrm{g}$ folic acid/d in addition to the normal diet leads to unmetabolised folic acid in the blood This suggests that not all folic acid supplied is available for the remethylation of homocysteine to methionine it is not clear whether this has negative effects or not, but possible negative effects of the use of supplemental folic acid should not be Ignored (Campbell, 1996, Savage and Lindenbaum, 1995, Tamura, 1995) Therefore, the search for the lowest effective dose still remains important

Although the question of whether a $250-\mu \mathrm{g} / \mathrm{d}$ dose long-term is as effective as 
a 500- $\mu \mathrm{g}$ dose still needs to be answered, this study showed that even a dose as low as $250 \mu \mathrm{g}$ folic acid/d effectively lowered plasma total homocysteine concentrations and increases the folate status of young healthy women. The fact that such low doses are effective suggests that intervention with natural food folate may also be feasible. Thus, the bioavailability of natural folates in foods should receive close attention (Wei et al., 1996). The results of this study indicate that food fortification with low doses of folic acid is a good option. 


\section{Acknowledgement}

We wish to thank the volunteers for their participation and M Laurinen, M Louwman, and $\mathrm{C}$ Schuurman for their assistance during the fieldwork, Robert Passas, Abbott Diagnostics, Maidenhead, UK, for his support with the IMx diagnostic testing kits, the laboratory staff of the division of Human Nutrition and Epidemiology of the Wageningen Agricultural University, the Laboratory of Endocrinology and Reproduction of the University Hospital Numegen St Radboud, and the Laboratory of Metabolic Diseases of the Wilhelmina Children's Hospital in Utrecht for their support and expert technical assistance

This work was supported by the Dutch Prevention Fund (28-2559), The Hague, the Netherlands Pharmachemie B V , Haarlem, the Netherlands kındly supplied the folıc acid and placebo tablets Abbott Diagnostics, Maidenhead, United Kingdom, provided the IMX diagnostıc testıng kits 


\section{Low-dose folic acid supplementation does not influence plasma methionine concentrations in young non-pregnant women}

Ingeborg A Brouwer, Marıke van Dusseldorp, Marınus Duran, Chris MG Thomas, Joseph GAJ Hautvast, Tom KAB Eskes, Régıne PM Steegers Theunissen.

Britssh Journal of Nutrition (In Press). 


\section{Abstract}

An elevated plasma total homocysteine concentration is a risk factor for cardiovascular disease and for having offspring with a neural-tube defect. Homocysteine is a transmethylation product of methionine and can be remethylated to methionine. Folate is a methyl donor in this remethylation reaction. Folic acid supplementation can decrease plasma total homocysteine concentrations. However, the effect of folic acid supplementation on plasma methionine concentrations is still unclear. There is also concern that folic acid supplementation would negatively affect the vitamin $\mathrm{B} 12$ status.

We studied the effects of low-dose folic acid supplementation on plasma methionine and on plasma vitamin B12 concentrations. We also investigated whether baseline plasma methionine and plasma total homocysteine concentrations correlated with the baseline folate and vitamin B12 status.

The experiment had a parallel design. During four weeks, 144 young women received either $500 \mu \mathrm{g}$ of folic acid each day, or $500 \mu \mathrm{g}$ of folic acid and placebo tablets on alternate days, or a placebo tablet each day. Plasma methionine, plasma total homocysteine and plasma vitamin $\mathrm{B} 12$ concentrations were measured at the start and at the end of the intervention period. Folic acid supplementation had no effect on plasma methionine or plasma vitamin B12 concentrations although it significantly decreased plasma total homocysteine concentrations. Plasma methionine concentrations showed no correlation with either plasma total homocysteine concentrations (Spearman $r_{3}=-0.01 ; P=0.89$ ), or any of the blood vitamin parameters at baseline. Baseline plasma total homocysteine concentrations showed a slight inverse correlation with baseline concentrations of plasma vitamin B12 $\left(r_{s}=-0.25, P<0.001\right)$, plasma folate $\left(r_{s}=-0.24, P<0.01\right)$ and red blood cell folate $\left(r_{\mathrm{s}}=-0.19, P<0.05\right)$.

In conclusion, low-dose folic acid supplementation did not influence plasma methionine or plasma vitamin B12 concentrations. Furthermore, no correlation between plasma methionine concentrations and the blood folate and vitamin B12 status was shown. 


\section{Introduction}

Homocysteine has received a lot of attention because hyperhomocysteinemia has been shown to be a risk factor for cardiovascular disease and for having offspring with a neural-tube defect (Boushey et al., 1995; Mills et al., 1995; Steegers Theunissen et al., 1994). Homocysteine is the transmethylation product of the essential amino acid methionine. Methionine can be transmethylated via S-adenosylmethionine and S-adenosylhomocysteine to homocysteine, which in turn can be remethylated to methionine (Fig.1.3 Chapter 1). Thus, in theory an increase in plasma methionine is expected after a decrease in plasma homocysteine. $\mathrm{N}$-5-methyltetrahydrofolate, the predominant form of the B-vitamin folic acid in the blood, serves as a methyl donor for this remethylation reaction and supplementation with folic acid decreases homocysteine concentrations (Brouwer et al., 1999; Ward et al., 1997). Vitamin B12 (methylcobalamin) is a co-factor in this remethylation reaction. Guttormsen et al. (1996b) showed that in folate or vitamin B12 deplete subjects supplementation with folic acid or vitamin B12 increased plasma methionine concentrations.

Already since 1947 there is concern that folic acid supplementation may have deleterious effects on cobalamin deficiency (Heinle and Welch, 1947). We therefore checked in this study whether low-dose folic acid supplementation influenced plasma vitamin $\mathrm{B} 12$ concentrations.

The present study aimed at determining the effects of low-dose folic acid supplementation on plasma methionine and plasma vitamin B12 concentrations in healthy volunteers. We compared these effects with the decreasing effect on plasma total homocysteine concentrations (Brouwer et al., 1999). We also examined whether plasma methionine and plasma total homocysteine concentrations correlated with the blood folate and vitamin B12 status.

\section{Subjects and Methods}

The methods of this experiment have previously been described in more detail in Chapter 2 (Brouwer et al., 1999). In short, these are as follows.

\section{Subjects}

We recruited healthy, non-pregnant women (18-40 years). Exclusion criteria were: smoking, gastrointestinal disorder, use of: vitamins, minerals, yeast or seaweed, 
Chapter 3

malarıa prophylaxes and antı-convulsants The final study group comprised 144 women

The Medical Ethical Committee of the Wageningen Agricultural University approved the study design All women gave written informed consent

\section{Methods}

After stratification for the use of oral contraceptives, the women were randomised over three intervention groups and received either $500 \mathrm{\mu g}$ of folic acid per day, or $500 \mu \mathrm{g}$ of folıc acıd and a placebo tablet every other day (on average $250 \mu \mathrm{g}$ of folıc acıd per day), or a placebo tablet daily (Pharmachemie BV, Haarlem, the Netherlands) for four weeks The group sizes in this study were chosen to detect an $11 \%$ decrease in plasma total homocysteıne concentrations after four weeks of intervention (Brouwer et al, 1999) The subjects and the laboratory staff were blind to the group assignment Subjects followed their regular diet except for refrainıng from the consumption of liver and marmite, a yeast extract $A$ 24-hour recall was obtained from each subject once durıng the intervention perıod to check their intake of macronutrients, vitamın B6, B12 and folate (Brants and Hulshof, 1995, Stıchtıng NEVO, 1993)

Venous blood samples were collected after overnıght fastıng at the start (week 0 ) and at the end of the four weeks intervention period (week 4) We determined plasma methıonıne concentratıons and plasma total homocysteıne, plasma folate, red blood cell folate and plasma vitamın $B 12$ concentratıons in all samples

\section{Measurements}

Samples for determınations in plasma were immediately placed on ice and centrifuged withın 60 mın at 3,000 $\times g$ for 10 mın Plasma was separated and stored at $-35^{\circ} \mathrm{C}$ for folate and vitamın $\mathrm{B12}$, at $-80^{\circ} \mathrm{C}$ for plasma total homocysteine and at $-20^{\circ} \mathrm{C}$ for methıonıne For determınatıon of folate concentrations in red blood cells, whole blood was diluted 5 -fold with aqueous sodium ascorbate $(10 \mathrm{~g} / \mathrm{L})$ and stored at $-35^{\circ} \mathrm{C}$ The haemolysates were further diluted with IMx Folate RBC Lysis Reagent (Abbott Laboratories, North Chicago, IL, USA) To be able to express the folate concentration in red blood cells, haematocrits were also measured

For methıonıne analysıs a quantıtatıve amıno acıd analysıs in plasma was performed on a Bıotronık 7000 amıno acıd analyser (Bıotronık, Maıntal, FRG) usıng S-(amınoethyl)cysteıne as internal standard The separation was achieved by a stepwise gradient of lithium citrate buffers, the detection and quantification was performed with the classıcal nınhydrın reaction and spectrophotometry at 440 and $570 \mathrm{~nm}$ The method had an inter- and Intra-assay coefficients of variation (CV) $<5 \%$ 
Plasma total homocysteine was measured by high-performance liquid chromatography (HPLC) technique and fluorimetric detection (intra- and inter-assay coefficients of variation <8\%) (Araki and Sako, 1987). Folate concentrations in plasma and red blood cells and vitamin B12 in plasma were determined with the Abbott IMx vitamin B12 and Folic Acid assays (Abbott Laboratories, North Chicago, IL, USA). The intra-assay $\mathrm{CV}$ of the folate assay was $<6 \%$, while the inter-assay $\mathrm{CV}$ was $<10 \%$. For vitamin B12, both the intra- and inter-assay CVs were lower than $5 \%$.

\section{Statistics}

The response to treatment was calculated for each subject as the change in plasma methıonine or plasma total homocysteine concentrations between the start (week 0 ) and the end of the intervention period (week 4). These responses were normally distributed as checked by visual inspection of the normal probability plots (univariate procedure; SAS Institute Inc, Cary, NC, USA). To analyse differences in response to intervention Student $t$-tests were used with a significance level of $P<0.05 / 3=0.017$. Spearman rank correlation coefficients were calculated for the blood parameters, because the concentrations (with the exception of plasma methionine) were not normally distributed.

\section{Results}

Four weeks of low-dose folic acid supplementation had no effect on plasma methionine concentrations, whereas folate concentrations in plasma and red blood cell increased and plasma total homocysteine concentrations decreased (Table 3.1; Brouwer et al., 1999). Intervention with folic acid had no effect on plasma vitamin B12 concentrations (Table 3.1).

The change (mean, $95 \% \mathrm{Cl}$ ) in plasma methionine in the $500-\mu \mathrm{g}$ group corrected for the change in the placebo group was $0.37(-1.6,2.3) \mu \mathrm{mol} / \mathrm{L}$; the change in plasma methionine in the $250-\mu \mathrm{g}$ group corrected for the change in the placebo group was $-1.2(-3.2,0.7) \mu \mathrm{mol} / \mathrm{L}$. Figure 3.1 shows the individual values of plasma methionine and plasma total homocysteine before and after intervention. 
Chapter 3

Table 3.1 Plasma folate, red blood cell folate, plasma vitamın B12, total plasma homocysteıne and plasma methıonıne concentrations before and after four weeks of folic acıd supplementatıon ${ }^{1}$

\begin{tabular}{|c|c|c|c|}
\hline & $\begin{array}{c}500 \mu g / d \text { group } \\
(n=45)\end{array}$ & $\begin{array}{c}250 \mu \mathrm{g} / \mathrm{d} \text { group } \\
(\mathrm{n}=50)\end{array}$ & $\begin{array}{l}\text { placebo group } \\
\qquad(n=49)\end{array}$ \\
\hline Inıtıal plasma folate (nmol/L) & $11 \pm 40$ & $11 \pm 34$ & $12 \pm 42$ \\
\hline Final plasma folate $(\mathrm{nmol} / \mathrm{L})$ & $27 \pm 51$ & $23 \pm 53$ & $17 \pm 61$ \\
\hline $\begin{array}{l}\text { Initial red blood cell folate } \\
(\mathrm{nmol} / \mathrm{L})\end{array}$ & $400 \pm 107$ & $386 \pm 85$ & $422 \pm 181$ \\
\hline $\begin{array}{l}\text { Final red blood cell folate } \\
(\mathrm{nmol} / \mathrm{L})\end{array}$ & $508 \pm 176$ & $432 \pm 126$ & $401 \pm 182$ \\
\hline $\begin{array}{l}\text { Inıtıal plasma vitamın B12 } \\
(\mathrm{nmol} / \mathrm{L})\end{array}$ & $265 \pm 117$ & $290 \pm 88$ & $286 \pm 110$ \\
\hline $\begin{array}{l}\text { Final plasma vitamın B12 } \\
\text { (pmol/L) }\end{array}$ & $265 \pm 110$ & $300 \pm 98$ & $287 \pm 121$ \\
\hline $\begin{array}{l}\text { Initial total plasma } \\
\text { homocysteine }(\mu \mathrm{mol} / \mathrm{L})\end{array}$ & $111 \pm 26$ & $97 \pm 22$ & $104 \pm 25$ \\
\hline $\begin{array}{l}\text { Final total plasma } \\
\text { homocysteine (nmol/L) }\end{array}$ & $85 \pm 17$ & $85 \pm 17$ & $103 \pm 25$ \\
\hline $\begin{array}{l}\text { Inıtıal plasma methıonıne } \\
(\mu \mathrm{mol} / L)\end{array}$ & $226 \pm 48$ & $234 \pm 43$ & $234 \pm 41$ \\
\hline $\begin{array}{l}\text { Final plasma methıonıne } \\
(\mu \mathrm{mol} / \mathrm{L})\end{array}$ & $237 \pm 57$ & $229 \pm 43$ & $241 \pm 47$ \\
\hline
\end{tabular}

' Values are presented as means $\pm S D$ 


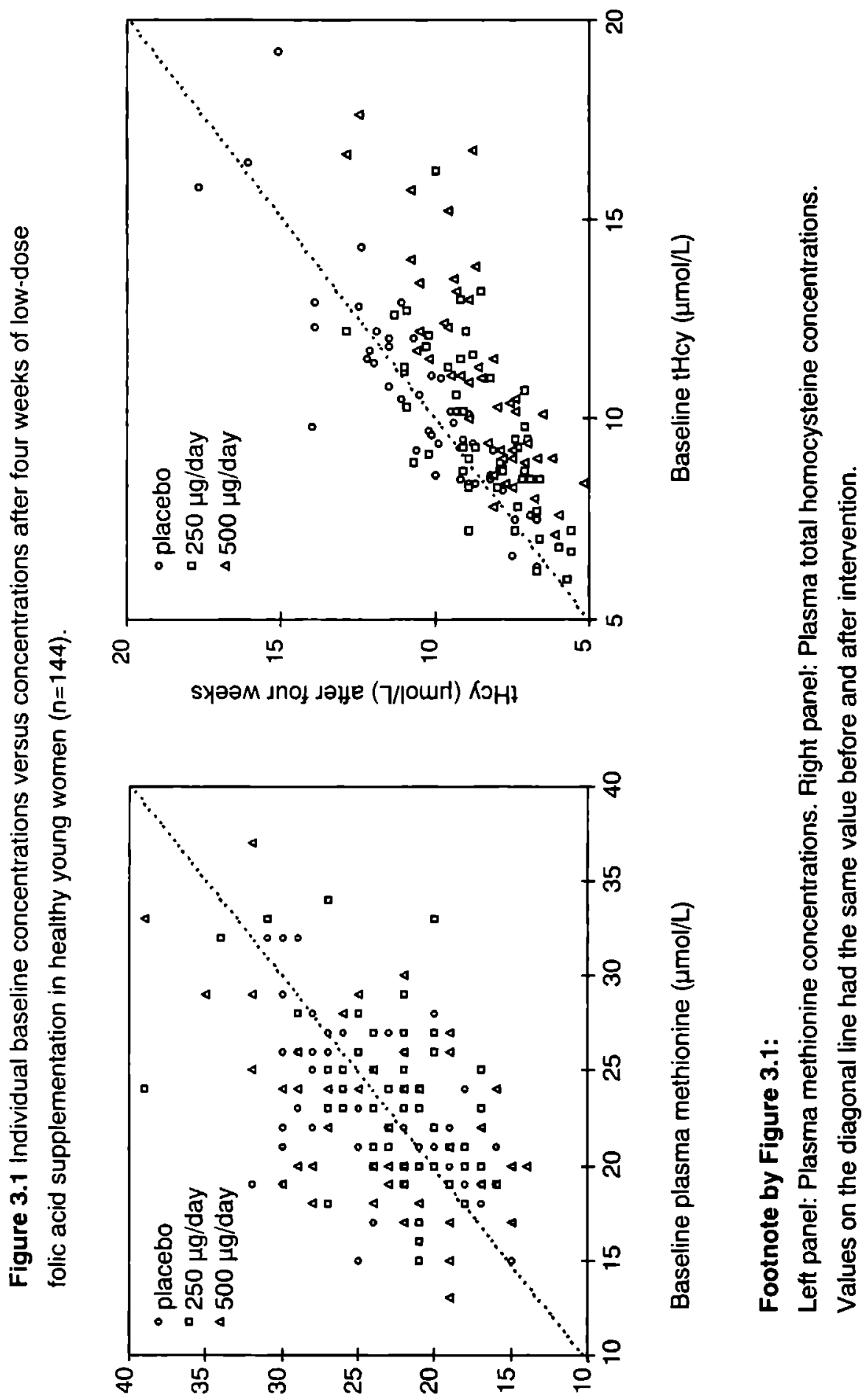

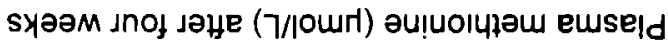


Baseline plasma total homocysteine and methionine concentrations of the subjects were not correlated (Spearman $r_{\mathrm{s}}=-0.01 ; P=0.89$ ). Baseline plasma total homocysteine concentrations showed a slight, but significant correlation with baseline concentrations of plasma vitamin $B 12\left(r_{s}=-0.25, P=0.003\right)$, plasma folate $\left(r_{\mathrm{s}}=-0.24, P=0.004\right)$ and red blood cell folate $\left(r_{\mathrm{s}}=-0.19, P=0.03\right)$. However, none of these blood vitamin concentrations correlated with plasma methionine concentrations.

Users of oral contraceptives ( $n=97$ ) had significantly lower baseline plasma vitamin B12 concentrations $(252 \pm 84 \mathrm{pmol} / L)$ than non-users $(n=47 ; 346 \pm 118$ $\mathrm{pmol} / \mathrm{L}$ ). However, no differences were observed for plasma total homocysteine and folate concentrations between users and non-users of oral contraceptives.

\section{Discussion}

This study shows that four weeks of low-dose folic acid supplementation did not influence plasma methionine or plasma vitamin B12 concentrations although it decreased plasma total homocysteine concentrations and increased plasma and red blood cell folate concentrations (Brouwer et al., 1999). Plasma methionine concentrations were also not correlated with plasma total homocysteine or plasma or red blood cell folate concentrations, while plasma total homocysteine concentrations were inversely correlated with these blood vitamin parameters.

In contrast to our study, Guttormsen et al. (1996b) showed significantly increased fasting plasma methionine concentrations after intervention with folic acid (5 mg per day for 10 days) and/or intramuscular injections with cobalamin $(3-5 \mathrm{mg}$ in 2-3 wk) (Guttormsen et al., 1996b). However, they supplied much higher doses of folic acid and all subjects in that study had a deficient or marginal folate and vitamin B12 status and elevated plasma homocysteine concentrations (Guttormsen et al., 1996b). Our results are in accordance with Jacob et al. (1995) who reported no effect of folate depletion and repletion on plasma methionine concentrations in healthy young men, although plasma total homocysteine concentrations increased after depletion and decreased after repletion (Jacob et al., 1994). All our subjects had plasma methionine concentrations in the normal range (Armstrong and Stave, 1973; Scriver et al., 1985), but they were not in optimal folate status because folic acid supplementation decreased their plasma total homocysteine concentrations (Brouwer et al., 1999). Effects of folic acid supplementation might be different in subjects with either high or low plasma methionine and plasma total homocysteine 
concentrations. Repetition of the analysis with exclusion of those subjects with plasma total homocysteine concentrations above $15 \mu \mathrm{mol} / \mathrm{L}$ did not change the results of the current study.

Potgieter et al. (1997) noticed that methionine is very sensitive to oxidation and may even be converted to methionine sulfoxide when samples are stored at $-20^{\circ} \mathrm{C}$ until analysis (Potgieter et al., 1997). Thus, in our study spontaneous oxidation of methionine might have occurred and it can not be excluded that this attributed to the lack of effect on plasma methionine.

Differences in methionine intake between the groups is not a very likely explanation for the lack of effect in the present study. Although we did not estimate methionine intake in the subjects, we know from a 24-hour recall administered to all participants during the trial that the total dietary protein intake and the intake of animal protein reflected by the vitamin B12 intake were similar among the groups (Brouwer et al., 1999). This suggests a comparable methionine intake between the groups. Besides, it is unlikely that a slight difference in methionine intake would have influenced plasma methionine concentrations. Jacob et al. (1995) showed that changes in the intake of dietary methyl groups did not influence plasma methionine concentrations. Moreover, Andersson et al. (1990) found that a 3-fold increase in the daily intake of methionine during 13 days had no effect on fasting plasma methionine concentrations on day 14 .

On the basis of the actual group sizes (placebo group: $n=49 ; 500 \mu g /$ day group: $n=45$ ) and the standard deviations for the change in plasma methionine (placebo group: $4.8 ; 500 \mu \mathrm{g} /$ day group: 5.1 ) and a power of $90 \%$, we calculated that a difference of $3.3 \mu \mathrm{mol} / \mathrm{l}$ in plasma methionine between the placebo and the 500 $\mu \mathrm{g} /$ day group would have been statistically significant. Therefore, we can exclude effects of low-dose folic acid supplementation on methionine above this level.

We found no effect of folic acid supplementation on plasma vitamin B12 concentrations. However, users of oral contraceptives had lower plasma vitamin B12 concentration than non-users at baseline. Plasma total homocysteine concentrations were not affected by use of oral contraceptives. These findings are in concordance with Green et al. (1998). They found 33\% lower plasma vitamin B12 concentrations, but similar plasma total homocysteine concentrations in adolescent females who used oral contraceptives than those who did not use oral contraceptives (Green et al., 1998). Our study suggests that this finding is not just confined to adolescent temales. 
Chapter 3

In conclusion, fasting plasma methionine levels in healthy women were not related to plasma folate and vitamin $\mathrm{B12}$ concentrations and were not influenced by low-dose folic acid supplementation.

\section{Acknowledgement}

The authors wish to thank the volunteers for their participation and Ms C Schuurman, Ms M Louwman and Ms M Laurinen for their assistance during the field work. We also thank Dr Robert Passas, Abbott Diagnostics, Maidenhaed, UK, for his support. We are grateful to the laboratory staff of the division of Human Nutrition and Epidemiology of the Wageningen Agricultural University, the laboratory of Endocrinology and Reproduction of the University Hospital Nijmegen St Radboud and the laboratory of Metabolic Diseases of the Wilhelmina Childrens Hospital in Utrecht for their support and expert technical assistance.

This work was supported by the Zorg Onderzoek Nederland / Dutch Praevention Fund (28-2559), The Hague, the Netherlands. Tablets (folic acid and placebo) were kindly supplied by Pharmachemie B.V., Haarlem, the Netherlands. Abbott Diagnostics, Maidenhead, UK, provided the IMx diagnostic testing kits. 


\section{4}

Homocysteine-lowering effect of $500 \mu \mathrm{g}$ of folic acid every other day versus $250 \mu \mathrm{g}$ per day

Brouwer IA, van Rooij IALM, van Dusseldorp M, Thomas CMG, Blom HJ, Hautvast JGAJ, Eskes TKAB, Steegers Theunissen RPM. 


\section{Abstract}

An elevated plasma total homocysteine concentration is considered a risk factor for neural-tube defects and for cardiovascular disease. Several studies showed that supplementation with low doses of folic acid decreases plasma total homocysteine concentrations. We investigated whether supplementation with $500 \mu \mathrm{g}$ of folic acid every other day is as effective in lowering plasma total homocysteine concentrations as supplementation with $250 \mu \mathrm{g}$ of folic acıd each day.

In a four-week intervention study, 22 healthy young women (18-40 yrs) took elther $500 \mu \mathrm{g}$ of folic acid every other day (500- $\mu \mathrm{g} / 2 \mathrm{~d}$ group) or $250 \mu \mathrm{g}$ of folic acid each day (250- $\mu \mathrm{g} / \mathrm{d}$ group). Fasting blood was collected at the start and the end of the intervention period.

Plasma folate concentrations increased by $11.4 \mathrm{nmol} / \mathrm{L}(68$ to 15.9$)$ in the $250-\mu \mathrm{g} / \mathrm{d}$ group and by $9.1 \mathrm{nmol} / \mathrm{L}(95 \% \mathrm{Cl} .19$ to 16.3$)$ in the $500-\mu \mathrm{g} / 2 \mathrm{~d}$ group. These increases were not significantly different from each other. Plasma total homocysteine concentrations decreased by $1.52 \mu \mathrm{mol} / \mathrm{L}$ (95\% Cl: -2.09 to $-0.95 ; P<$ $0001)$ in the $250-\mu \mathrm{g} / \mathrm{d}$ group and by $0.88 \mu \mathrm{mol} / \mathrm{L}(-153$ to $-0.23 ; P<0.05)$ in the 500 $\mu \mathrm{g} / 2 \mathrm{~d}$ group The difference in decrease of $0.64 \mu \mathrm{mol} / \mathrm{L}$ between the $250-\mu \mathrm{g} / \mathrm{d}$ group and the $500-\mu g / 2 d$ group was not significant $(P=011)$. Although not conclusively, this study suggests that supplying subjects with folic acid each day decreases plasma total homocysteine more effectively than a double dose of folic acid every other day. The frequency of supplementation with folic acid might influence plasma total homocysteıne concentrations 


\section{Introduction}

Several studies have shown that low-dose folic acid supplementation decreases plasma total homocysteine concentrations (Ward et al., 1997; Homocysteine Lowering Trialists' Collaboration, 1998; Brouwer et al., 1999). This is of importance because elevated homocysteine concentrations are considered a risk factor for cardiovascular disease and neural-tube defects (Steegers Theunissen et al., 1994; Mills et al. . 1995; Boushey et al., 1995; Graham et al., 1997). Moreover, plasma total homocysteine is regarded as a functional marker of the folate status (Jacob et al., 1994).

In the study of Brouwer et al. (1999) we supplemented healthy young women for a period of four weeks with tablets containing either $500 \mu \mathrm{g}$ of folic acid each day, or every other day with placebo tablets on alternate days. Although not to the same extent, both intervention strategies decreased plasma total homocysteine concentrations. The intervention with $500 \mu \mathrm{g}$ each day decreased plasma homocysteine concentrations with on average $22 \%$, while $500 \mu \mathrm{g}$ of folic acid every other day decreased the concentrations by $11 \%$. Kelly et al. (1997) showed that unaltered folic acid appears in the serum of subjects receiving more than $266 \mu \mathrm{g}$ of folic acid in addition to the usual diet. This unaltered folic acid is fully oxidised. Folate in the reduced tetrahydrofolate form can bind to one-carbon units and serve as a methyl group donor in the reaction of homocysteine to methionine (Wagner, 1995). Therefore, folic acid needs to be reduced before it can lower homocysteine. Besides, storage of folic acid is likely to be less effective than of other folate forms (Shane, 1995; Wagner, 1995). Thus, a dose of folic acid of $500 \mu$ per 2 days might be less effective than $250 \mu \mathrm{g}$ each day.

In the current study we investigated whether supplementation of women with $500 \mu \mathrm{g}$ of folic acid every other day is as effective in lowering plasma total homocysteine concentrations as supplementation with $250 \mu \mathrm{g}$ of folic acid each day. We hypothesised that the two intervention strategies would result in a similar increase in plasma folate concentrations. However, $250 \mu \mathrm{g}$ of folic acid each day was expected to decrease plasma total homocysteine concentrations more effectively than $500 \mu \mathrm{g}$ of folic acid every other day. 


\section{Subjects and Methods}

\section{Subjects}

Healthy, non-pregnant women (18-40 years) were recruited within the University Hospital St Radboud in Nijmegen, the Netherlands. Women were excluded if they were smokers, had a gastrointestinal disorder, or had used any of the following preparations during the three months preceding the trial: vitamins, minerals, yeast or seaweed, malaria prophylaxis and anti-convulsants. Based on these criteria we included 22 women in the study.

The Medical Ethical Committee of the University Hospital Nijmegen St Radboud approved the study design. All women gave written informed consent.

\section{Methods}

Subjects were divided into two intervention groups. During four weeks, they either received one tablet of $500 \mathrm{\mu g}$ of folic acid every other day and placebo tablets on the alternate days $(500 \mu \mathrm{g} / 2 \mathrm{~d}$ group), or $250 \mu \mathrm{g}$ of folic acid each day (250 $\mu \mathrm{g} / \mathrm{d}$ group) (Pharmachemie B.V., Haarlem, the Netherlands). Subjects in the group receiving $500 \mu \mathrm{g}$ of folic acid and placebo tablet on alternate days received two containers of tablets, one marked with a red and one with a yellow sticker. These subjects received a calendar in which the days were alternately marked red and yellow. Subjects in the group receiving $250 \mu \mathrm{g}$ of folic acid each day also received a tablet calendar. Subjects were asked to follow their regular diet, except for refraining from the consumption of liver and marmite, a yeast extract. All subjects reported intake of tablets on their tablet calendar.' To study compliance, we counted any remaining tablets and checked the reported intake of tablets on the calendar. The subjects always took their tablets before breakfast and on blood collection days after fasting blood sampling.

Venous blood samples were collected after overnight fasting at the start (week 0) and the end (week 4) of the four-week intervention period. Plasma total homocysteine and plasma folate concentrations were determined in all samples.

Blood samples were drawn in EDTA vacutainer tubes (Venoject II, Terumo, Madrid, Spain). For the determination of plasma total homocysteine and plasma folate samples were immediately placed on ice and centrifuged within 60 minutes at $3,000 \times g$ for 10 minutes. Plasma was separated and stored at $-35^{\circ} \mathrm{C}$ for folate and at $-80^{\circ} \mathrm{C}$ for plasma total homocysteine determination until required for analysis. Folate concentrations in plasma were determined with the Abbott IMx Folic Acid assay, which is based on ion-capture technology for the IMx automated immunoassay 
system (Abbott Laboratories, North Chicago, IL, USA). The intra-assay coefficients of variance (CV) of the folate assay varied between $3 \%$ and $6 \%$, while the inter-assay CV varied between $6 \%$ and $10 \%$, depending on the folate concentration. Homocysteine was measured by high performance liquid chromatography (HPLC) essentially according to the method of Fiskerstrand et al. (Fiskerstrand et al., 1993) with some modifications (te Poele-Pothoff et al., 1995). The intra- and inter-assay CV were $<6.5 \%$. All samples from each subject were analysed in the same run.

\section{Statistical analyses}

The responses to the various treatments were calculated for each subject as the change in plasma total homocysteine and plasma folate, between the start (week 0 ) and the end (week 4) of the intervention period. The changes in folate and plasma total homocysteine concentrations were normally distributed. Student t-tests were used to analyse differences in response of plasma total homocysteine and plasma folate between the two groups $(P<0.05)$. Paired t-tests were used for comparisons within the groups $(P<0.05)$.

\section{Results}

Four weeks of supplementation with $250 \mu \mathrm{g}$ of folic acid each day or $500 \mu \mathrm{g}$ of folic acid and placebo treatment on alternate days increased plasma folate concentrations in both groups (Figure 4.1). The mean increase of $11.4 \mathrm{nmol} / \mathrm{L}(6.8$ to 15.9$)$ in the $250 \mu \mathrm{g} / \mathrm{d}$ group was not significantly different from the $9.1 \mathrm{nmol} / \mathrm{L}(95 \% \mathrm{Cl}: 1.9$ to 16.3) increase in the $500 \mu \mathrm{g} / 2 \mathrm{~d}$ group.

Plasma total homocysteine concentrations significantly decreased in both intervention groups (Figure 4.2). Plasma total homocysteine concentrations decreased in the $250 \mu \mathrm{g} / \mathrm{d}$ group by $1.52 \mu \mathrm{mol} / \mathrm{L}(95 \% \mathrm{Cl}:-2.09$ to $-0.95 ; P<0.001)$ and in the $500 \mu \mathrm{g} / 2 \mathrm{~d}$ group by $0.88 \mu \mathrm{mol} / \mathrm{L}(-1.53$ to $-0.23 ; P<0.05)$. Although plasma total homocysteine concentrations in the $250 \mu \mathrm{g} / \mathrm{d}$ group decreased 0.64 $\mu \mathrm{mol} / \mathrm{L}$ more than in the $500 \mu \mathrm{g} / 2 \mathrm{~d}$ group, this difference was not significant $(P=0.11)$.

Although not significantly different, the mean baseline concentration of plasma total homocysteine was slightly higher in the $250 \mu \mathrm{g} / \mathrm{d}$ group (mean $11.3 \mu \mathrm{mol} / \mathrm{L}$; 95\% Cl: 9.9 to 12.7 ) than in the $500 \mu \mathrm{g} / 2 \mathrm{~d}$ group (10.3 $\mu \mathrm{mol} / \mathrm{L} ; 9.2$ to 11.4 ). The decrease in plasma total homocysteine by intervention with folic acid is known to be dependent on the initial plasma total homocysteine concentration. Therefore, we 
corrected for this by repeating the analysis with exclusion of the subjects with the two highest and the two lowest baseline concentrations of plasma total homocysteine. The mean baseline concentration of plasma total homocysteine of the 18 remaining subjects ( $\mathrm{n}=9$ per group) was $10.5 \mu \mathrm{mol} / \mathrm{L} \pm 1.4$ (SD) in the $250 \mu / \mathrm{d}$ group and 10.8 $\mu \mathrm{mol} / \mathrm{L} \pm 1.7$ in the $500 \mu / 2 \mathrm{~d}$ group. The mean change over the intervention period was now $-1.48(-2.19,-0.76) \mu \mathrm{mol} / \mathrm{L}$ in the $250 \mu \mathrm{g} / \mathrm{d}$ group and $-0.99(-1.79,-0.19)$ $\mu \mathrm{mol} / L$ in the $500 \mu / 2 d$ group. The difference between the two intervention groups was not significantly different, but the decrease in the $250 \mu \mathrm{g} / \mathrm{d}$ group was still $150 \%$ of the decrease in the $500 \mu \mathrm{g} / 2 \mathrm{~d}$ group.

Figure 4.1 Individual baseline plasma folate concentrations versus concentrations after four weeks of low-dose folic acid supplementation in healthy young women $(n=22)$. Values on the diagonal line had the same value before and after intervention.

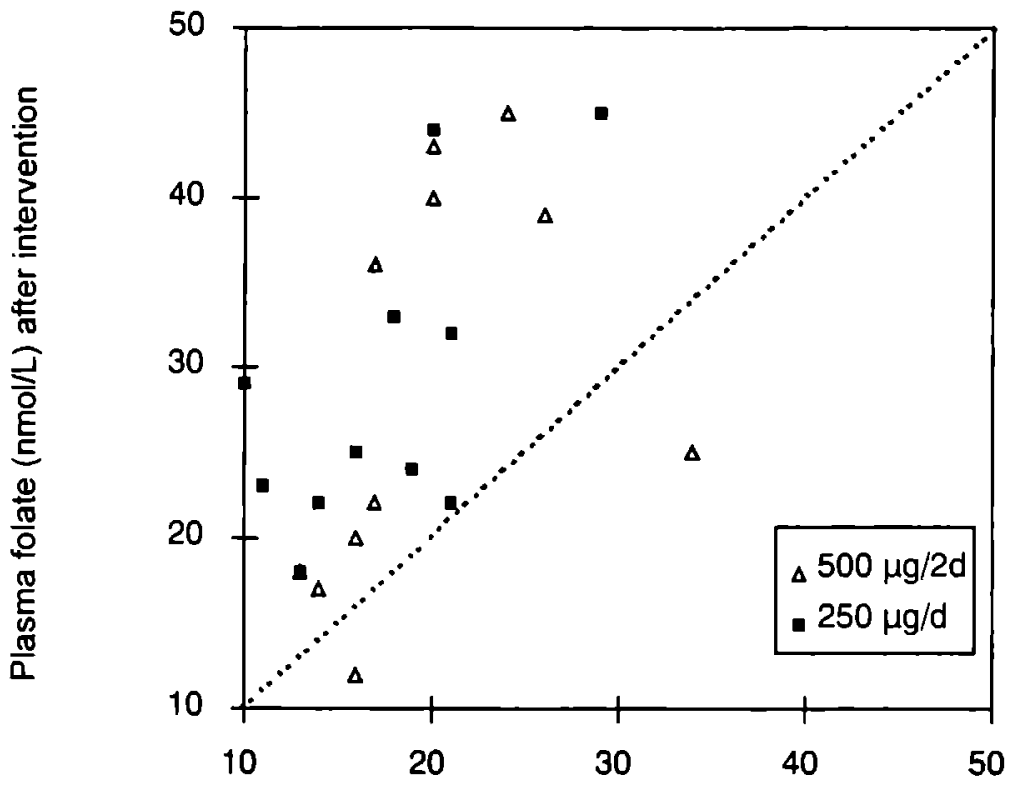

Plasma folate (nmol/L) before intervention 
Figure 4.2 Individual baseline plasma total homocysteine concentrations versus concentrations after four weeks of low-dose folic acid supplementation in healthy young women $(n=22)$. Values on the diagonal line had the same value before and after intervention.

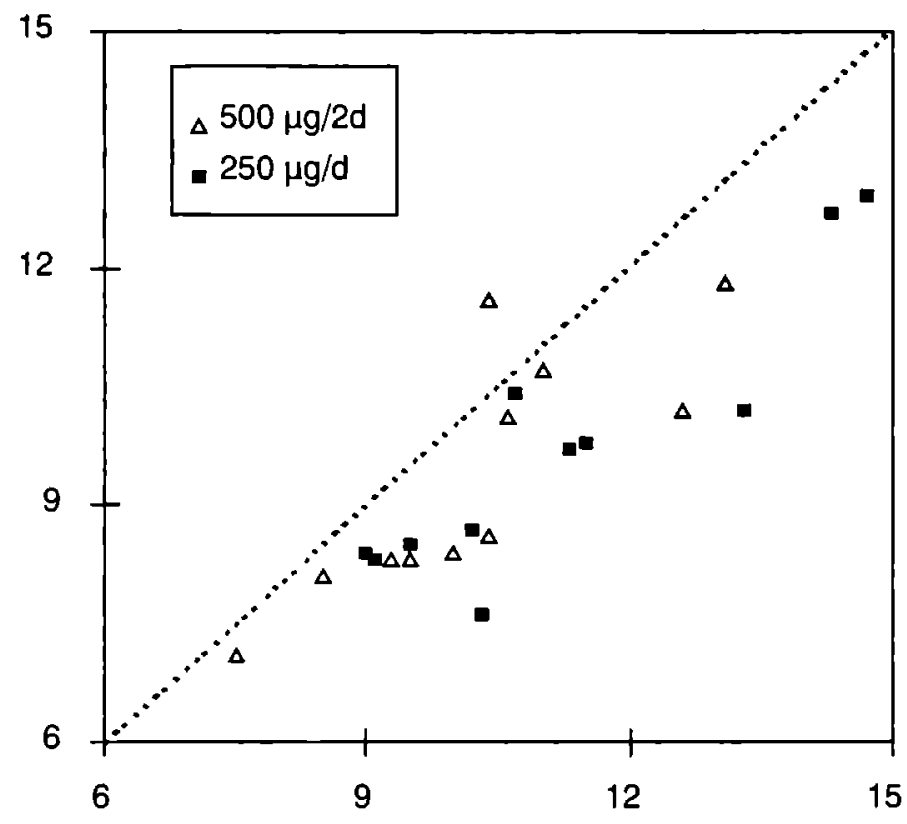

Total plasma homocysteine $(\mu \mathrm{mol} / \mathrm{L})$ before intervention

\section{Discussion}

Although this study cannot give conclusive evidence, it suggests that supplying subjects with folic acid each day decreases plasma total homocysteine more effectively than a double dose of folic acid every other day. Thus, the frequency of supplementation with folic acid might influence plasma total homocysteine concentrations

Folic acid supplementation in doses as low as 200 to $500 \mu \mathrm{g}$ daily has been shown to be effective in lowering plasma total homocysteine concentrations (Ward et 
al, 1997, Homocysteine Lowering Trualısts' Collaboration, 1998, Brouwer et al, 1999) Kelly et al (1997) showed that unaltered folic acid appears in the serum two hours after intake of a single dose of folic acid above $266 \mu \mathrm{g}$ This unaltered folic acid has no homocysteine lowering potential and needs to be reduced before it becomes metabolically active

We compared the strategy of supplying subjects with $500 \mu \mathrm{g}$ of folic acid every other day with supplying subjects with $250 \mu \mathrm{g}$ each day. The reduction in plasma total homocysteine tended to be more pronounced in the $250 \mu \mathrm{g} / \mathrm{d}$ group than in the $500 \mu \mathrm{g} / 2 \mathrm{~d}$ group However, we could not show any significant differences in responses between the two intervention strategies Eleven subjects per group participated in this study With this sample size we could have shown a significant difference of $11 \mu \mathrm{mol} / \mathrm{L}(\alpha=005, \beta=020$ ) Therefore, the lack of significance is likely to be caused by the small sample size

We hypothesised that $250 \mu \mathrm{g}$ of folic acid dally would increase plasma folate to the same extent as $500 \mu \mathrm{g}$ every other day The folate increasing effect was comparable for the $250 \mu \mathrm{g} / \mathrm{d}$ group (mean $114,95 \% \mathrm{Cl} 68$ to $159 \mu \mathrm{mol} / \mathrm{L}$ ) and the $500 \mu \mathrm{g} / 2 \mathrm{~d}$ group $(91,19$ to $163 \mu \mathrm{mol} / \mathrm{L})$ Based on the study of Kelly et al (1997) it is likely that a dose of folic acid of $500 \mu \mathrm{g}$ results in the appearance of unaltered folic acid in the blood However, the assay we used to determıne plasma folate measures unaltered folic acid as well as 5-methyl-tetrahydrofolate Therefore, we expected to find no difference in plasma folate response On the other hand, it is known that only reduced folate can bind one-carbon units (Wagner, 1995) Moreover, monoglutamates can be elongated to polyglutamates by adding glutamate units with the enzyme folylpoly- $\gamma$-glutamate synthetase This is of importance because tissues can only retain folylpolyglutamates and not monoglutamates in contrast to dihydrofolate and tetrahydrofolate is folic acid a very poor substrate for folylpoly- $\gamma$ glutamate synthetase (Shane, 1995) Therefore, less folic acid will be converted to pteroylpolyglutamates compared to the reduced forms of folate and more unaltered folic acid than other folate forms may be excreted Furthermore, polyglutamates of tetrahydrofolate forms are better substrates for enzymes of folate metabolism than monoglutamates (Shane, 1995)

Previous studies investigating the effect of folic acid on plasma total homocysteıne have mainly used either one tablet daily, or a sıngle dose of fortified food (Ward et al, 1997, Homocysteine Lowering Trialists' Collaboration, 1998, Brouwer et al, 1999, Malınow et al, 1998, Schorah et al, 1998) With doses above $266 \mu \mathrm{g}$ per day it might be expected that several small doses spread out over the day have more homocysteine-lowering effect than one single high dose food 
fortification programs as implemented in the US may therefore be more effective than the use of folic acid tablets. Our study lasted only four weeks, therefore it is possible that over a longer period a high dose supplied every other day has a similar homocysteine lowering potential as half the dose supplied each day. However, supplementation with a dose above $266 \mu \mathrm{g}$ implies that unaltered folic acid is present in the blood. Whether this has negative consequences or not is unclear (Kelly et al., 1997).

In conclusion, our study suggests that the frequency of supplementation might influence plasma total homocysteine concentrations. Future studies could investigate the effect of several doses spread out over the day versus a single dose with the same total folic acid content. 


\section{Acknowledgement}

We would like to thank the volunteers for their participation We also thank Ms $N$ Hamel-van Bruggen for her assistance durıng the blood collections, the Laboratories of Chemical Endocrinology, and Paediatrics and Neurology of the University Hospital Nımegen St Radboud for their support and expert technical assıstance

Supported by a grant from the Dutch "Praeventiefonds" / Zorg Onderzoek Nederland (28-2559), The Hague, the Netherlands Pharmachemie BV, Haarlem, the Netherlands, kindly supplied the folic acid and placebo tablets Abbott Diagnostics, Maidenhead, United Kıngdom provided the IMx diagnostıcs testıng kits 
Homocysteine metabolism and effects of folic acid supplementation in patients affected with spina bifida

Ingeborg A Brouwer, Marijke van Dusseldorp, Chris MG Thomas, Nathalie MJ van der Put, Michael A Gaytant, Tom KAB Eskes, Joseph GAJ Hautvast, Régine PM Steegers Theunissen. 


\section{Abstract}

Folic acid supplementation around conception decreases the risk of having offspring with a neural-tube defect in most cases however the aetıology behınd it is still unknown This study investigated whether patients with spina bifida have lower concentrations of blood folate and higher concentrations of fasting and postmethıonine-load plasma total homocysteıne than control patıents Moreover, effects of supplementation with $500 \mu \mathrm{g}$ folic acid/d on the folate status and plasma total homocysteine concentrations in spına bifida and control patients were determıned

The study population consisted of two groups spina bifida patıents $(n=12)$ and control patients $(n=15)$ living in the same institute Subjects in both groups received four weeks of placebo treatment followed by four weeks of intervention with $500 \mu \mathrm{g}$ folic acıd/d Blood was collected at day 0 , after 4 and after 8 weeks A methınıneloading test was pertormed at the start and the end of the study

At baselıne, blood folate and plasma total homocystenne concentratıons were not significantly different between the spina bifida and the control group Intervention with folic acid significantly increased plasma and red blood cell folate concentrations in both groups Folic acid decreased fasting plasma total homocysteine concentrations in the control group by $16 \pm 05 \mu \mathrm{mol} / \mathrm{L}(P<001)$ and in the spina bifida patients by $22 \pm 13 \mu \mathrm{mol} / \mathrm{L}(P=010)$

This study does not show a derangement in homocysteıne metabolism in spina bifida compared to control patients Moreover, folic acıd supplementation seems at least as effective in spina bifida patients as in controis 


\section{Introduction}

Folic acid supplementation around conception decreases the risk of having offspring with a neural-tube defect by more than $50 \%$ (Czeizel and Dudás, 1992; MRC Vitamin Study Research Group, 1991). Women with no history of a neural-tube defected pregnancy are advised to take 400-500 $\mu \mathrm{g}$ extra folic acid from at least four weeks before conception up until the eighth week of pregnancy (Centers for Disease Control, 1992; Expert Advisory Group, 1992). The US government has mandated food producers to fortify flour with $140 \mu \mathrm{g}$ of folic acid per $100 \mathrm{~g}$ to increase the intake of folic acid in women of reproductive age (US Department of Health and Human Services. Food and Drug Administration, 1996).

Although folic acid supplementation clearly decreases the risk of having a child with a neural-tube defect, in most cases the aetiology behind it is still unknown. Steegers Theunissen et al. (1994) showed that a sub-group of women who previously had a pregnancy affected by a neural-tube defect had elevated concentrations of total homocysteine in plasma. Homocysteine is a demethylation product of the essential amino acid methionine. Folate donates a methyl group to homocysteine to form methionine in this remethylation reaction. Intake of low doses of folic acid (200-500 $\mu \mathrm{g} / \mathrm{d}$ ) decreases plasma total homocysteine concentrations in healthy volunteers (Brouwer et al., 1999; den Heijer et al., 1998; Dierkes et al., 1998; Ward et al., 1997).

The C677T mutation in the methylenetetrahydrofolate reductase gene is one of the causes of an elevated plasma total homocysteine concentration. This polymorphism has been shown to be more frequent in patients with a neural-tube defect than in controls (van der Put et al., 1995; Whitehead et al., 1995). However, it explains only approximately $8 \%$ of all cases (van der Put et al., 1997a).

Van der Put et al. (1997b) studied the folate and plasma total homocysteine status of patients with spina bifida, the most common form of a neural-tube defect. They showed that plasma folate concentrations were lower and plasma total homocysteine and red blood cell folate concentrations were elevated in spina bifida patients compared to control subjects. However, studies investigating folate concentrations in serum and red blood cells of foetuses affected with a neural-tube defect found no differences with control foetuses (Economides et al., 1992; Thorand et al., 1996).

This study investigated whether patients with a spina bifida have lower baseline concentrations of blood folate and higher baseline concentrations of plasma 
total homocysteine than control patients. We also studied the effects of methionineloading on plasma total homocysteine concentrations in both groups. Moreover, this is the first study investigating the effects of folic acid supplementation on the folate status and plasma total homocysteine concentrations of spina bifida and control patients.

\section{Subjects and Methods}

\section{Subjects}

Subjects, aged 14 to 55 years (13 men and 15 women) were recruited from two institutes for disabled people in the Netherlands Werkenrode, Groesbeek and Het Dorp, Arnhem). Both spina bifida patients and control subjects were living in similar circumstances in the same institutes. Exclusion criteria were metabolic diseases, epilepsy, use of drugs interfering with folate metabolism, and use of vitamin or mineral supplements in the three months preceding the experiment. None of the women were pregnant or planning to become pregnant during the study. Only patients with spina bifida aperta $(n=12)$ were included in the spina bifida group. Subjects in the control group $(n=15)$ were suffering from transverse lesion $(n=4)$, history of polio myelitis $(n=2)$, contusio cerebri $(n=2)$, femur fibula ulna (FFU) syndrome $(n=1)$, spasms $(n=1)$, hernia diafragmatica $(n=1)$, attention deficit hyperkinetic disorder (ADHD) $(n=1)$, achondroplasia $(n=1)$, or status after removal of a tumor of the cerebellum $(n=1)$, status after several medical problems in the past $(n=1)$.

The study was approved by the Medical Ethical Committee of the Catholic University Nijmegen, and all participants gave their written informed consent. Parents or caretakers of all subjects under the age of 18 gave written permission for the adolescents to participate.

\section{Design}

The trial had a parallel design with a run-in period. All subjects received a placebo tablet daily for the first four weeks and a $500 \mu \mathrm{g}$ folic acid tablet for the following four weeks. Subjects kept their regular diet during the intervention period.

\section{Tablets}

Placebo tablets and folic acid tablets were indistinguishable from each other. The subjects were blind to whether they received placebo or folic acid tablets. 


\section{Methionine-loading test}

An oral methionine-loading test was performed at the beginning of the experiment (i.e., at the start of the run-in period) and eight weeks later, at the end of the experiment (i.e., at the end of the folic acid intervention period). After an overnight fast, venous blood was collected for measurement of total homocysteine and vitamin concentrations. Immediately after the fasting blood collection, the subjects took $0.1 \mathrm{~g}$ L-methionine $/ \mathrm{kg}$ body weight mixed in $200 \mathrm{~mL}$ of orange juice. All participants consumed a standardised breakfast and luncheon. For practical reasons, a second blood sample for measuring the (post-load) total homocysteine concentration was drawn from each subject five hours after the fasting sample. Both blood samples were taken at the same time for each subject for the first and the second methionineloading test.

\section{Blood sampling and analysis}

Venous blood samples were collected after overnight fasting at the start of the placebo period, at the end of the placebo period (start of the folic acid intervention period), and at the end of the folic acid intervention period. Plasma total homocysteine, plasma folate, red blood cell folate and whole blood pyridoxal-5'phosphate (PLP) concentrations were determined in all samples. Plasma vitamin B12 concentrations were assessed at the start of the experiment.

Blood samples for plasma total homocysteine, folate and vitamin B12 were drawn into EDTA vacutainer tubes. Blood was collected into heparinised vacutainer tubes for determination of PLP in whole blood. For the determination of plasma total homocysteine and plasma folate concentrations, samples were immediately placed on ice and centrifuged within 2 hours at $3,000 \times g$ for $10 \mathrm{~min}$. Plasma was separated and stored at $-35^{\circ} \mathrm{C}$ for folate determination and at $-80^{\circ} \mathrm{C}$ for total homocysteine determination. For determination of folate concentrations in red blood cells, whole blood was diluted 5 -fold with aqueous sodium ascorbate $(1 \mathrm{~g} / 100 \mathrm{~mL})$ and stored at $-35^{\circ} \mathrm{C}$. Before measurement, the haemolysates were further diluted with IMX Folate RBC Lysis Reagent (Abbott Laboratories, North Chicago, IL, USA). To be able to express the folate concentration in red blood cells, haematocrits were also measured. Correction was made for the concentration of folate in plasma. Homocysteine was measured by high performance liquid chromatography (HPLC) essentially according to the method of Fiskerstrand et al. (Fiskerstrand et al., 1993) with some modifications (te Poele-Pothoff et al., 1995). The intra- and interassay $\mathrm{CVs}$ were $<6.5 \%$. Folate concentrations in the haemolysates were determined with the Abbott IMx Folic acid assay, which is based on ion-capture technology for the IMx automated immunoassay system (Abbott Laboratories, North Chicago, IL, USA). 
Chapter 5

The intra-assay CV was $<6 \%$, while the interassay $C V$ was $<10 \%$. All samples from each subject were analysed in the same run. Determination of vitamin B6 as PLP in whole blood was performed by HPLC technique (Schrijver et al., 1981). The intraand interassay $\mathrm{CV}$ for the method was $1.6 \%$ and $5.5 \%$ respectively.

The C677T mutation was determined by polymerase chain reaction of a genomic DNA fragment followed by restriction enzyme analysis with Hinfl (Frosst et al., 1995).

\section{Statistical analyses}

The frequency distribution curves of the absolute values were skewed. Therefore, these values are reported as medians with 25 and 75 percentile values. For the statistical analysis of the absolute values the data were log-transformed to obtain normality. In cases where normality could not be obtained by log-transformation (age) a Wilcoxon non-parametric test was used.

The response to treatment was calculated for each subject as the change in fasting plasma total homocysteine, plasma or red blood cell folate, or whole blood vitamin B6 during the intervention period minus the change during the placebo period. Post-load homocysteine was only measured at the start and the end of the study. Therefore, change in post-load homocysteine was calculated as concentration after the intervention period minus concentration at the start of the study. Changes in folate and homocysteine concentrations were normally distributed as checked by visual inspection of the normal probability plots (univariate procedure; SAS Institute Inc, Cary, NC, USA). To analyse differences between the groups in response to treatment Student t-tests were used and considered significant at $P<0.05$. Paired ttests were used to analyse changes within groups.

\section{Results}

\section{Start of the study}

At the start of the study, no significant differences were apparent between the spina bifida and the control group for any of the measured variables (Table 5.1). The mean age of the spina bifida patients was $25.3 \pm 12.6$ years and the mean age of the control subjects was $29.3 \pm 16.2$ years. This difference was also not significant.

Two subjects from the control group withdrew from the study after the first blood collection for personal reasons. 


\section{Effect of intervention with folic acid}

We excluded one subject in the spina bifida group because of non-compliance to the folic acid therapy.

Table 5.1 Baseline biochemical indices in blood of spina bifida patients and disabled control subjects.

\begin{tabular}{|c|c|c|c|c|}
\hline & Spina Bifida & & Controls & \\
\hline Variable & Median $(25-75 \%)$ & $\mathbf{n}$ & Median (25-75\%) & $\mathbf{n}$ \\
\hline Hemoglobin (mmol/L) & $8.3(7.8$ to 8.5$)$ & 12 & $8.8(8.3$ to 9.5$)$ & 15 \\
\hline Hematocrit $(L / L)$ & $0.40(0.39$ to 0.42$)$ & 12 & $0.42(0.40$ to 0.45$)$ & 15 \\
\hline ASAT (IU/I) & $13(10$ to 19$)$ & 12 & $15(13$ to 21$)$ & 15 \\
\hline ALAT (IU/L) & $12(10$ to 20$)$ & 12 & $14(10$ to 32$)$ & 15 \\
\hline $\begin{array}{l}\text { Alkaline Phosphatase } \\
\text { (IU/L) }\end{array}$ & 67 (52 to 72$)$ & 12 & $71(61$ to 116$)$ & 15 \\
\hline Creatinine $(\mu \mathrm{mol} / \mathrm{L})$ & $62(57$ to 76$)$ & 12 & 75 (58 to 85$)$ & 15 \\
\hline Plasma folate $(\mathrm{nmol} / \mathrm{L})$ & $11(10$ to 13$)$ & 12 & $14(11$ to 16$)$ & 15 \\
\hline $\begin{array}{l}\text { Red blood cell folate } \\
(\mathrm{nmol} / \mathrm{L})\end{array}$ & 370 (340 to 400$)$ & 12 & $330(290$ to 430$)$ & 15 \\
\hline $\begin{array}{l}\text { Plasma vitamin B12 } \\
\text { (pmol/L) }\end{array}$ & 250 (165 to 370$)$ & 12 & $290(200$ to 360$)$ & 15 \\
\hline $\begin{array}{l}\text { Whole blood vitamin } \\
\text { B6 (nmol/L) }\end{array}$ & $38(33$ to 45$)$ & 12 & $36(26$ to 47$)$ & 15 \\
\hline $\begin{array}{l}\text { Fasting total plasma } \\
\text { homocysteine } \\
(\mu \mathrm{mol} / \mathrm{L})\end{array}$ & $11.1(10.1$ to 13.9$)$ & 12 & $10.2(8.8$ to 12.4$)$ & 15 \\
\hline $\begin{array}{l}\text { Post-load total plasma } \\
\text { homocysteine } \\
\text { ( } \mu \mathrm{mol} / \mathrm{L} \text { ) }\end{array}$ & 30.1 (28.7 to 43.4$)$ & 11 & 28.7 (26.7 to 37.3$)$ & 14 \\
\hline
\end{tabular}


Chapter 5

Table 5.2 Change in plasma folate, red blood cell folate, whole blood vitamin B6, and tHcy concentrations (pre- and postload) during four weeks of intervention with $500 \mu \mathrm{g}$ of folic acid corrected for the change during four weeks of placebo treatment in patients with a spina bifida and controls.

\begin{tabular}{ccc}
\hline & Spina bifida & Controls \\
& mean \pm SE & mean \pm SE \\
\hline Plasma folate & $15.4 \pm 1.4^{\star \star \star}$ & $14.8 \pm 3.1^{\star \star \star}$ \\
(nmol/L) & $(n=11)$ & $(n=12)$ \\
Red blood cell folate (nmol/L) & $151 \pm 15^{\star \star \star}$ & $102 \pm 33^{\star}$ \\
Whole blood vitamin B6 & $(n=11)$ & $(n=12)$ \\
(nmol/L) & $2.6 \pm 1.9$ & $2.0 \pm 2.7$ \\
Fasting total plasma & $(n=11)$ & $(n=12)$ \\
homocysteine ( $\mu$ mol/L) & $-2.2 \pm 1.3$ & $-1.6 \pm 0.5^{\star \star}$ \\
Total plasma homocysteine \\
after methionine-loading test
\end{tabular}

Significant effect of intervention with $500 \mu \mathrm{g}$ folic acid: $P<0.001$, ${ }^{\star} P<0.01$, ${ }^{\star} P<0.05$. 
Figure 5.1 Plasma total homocysteine concentrations before (start) and after intervention with $500 \mu \mathrm{g}$ of folic acid every day for four weeks in spina bifida and control patients.
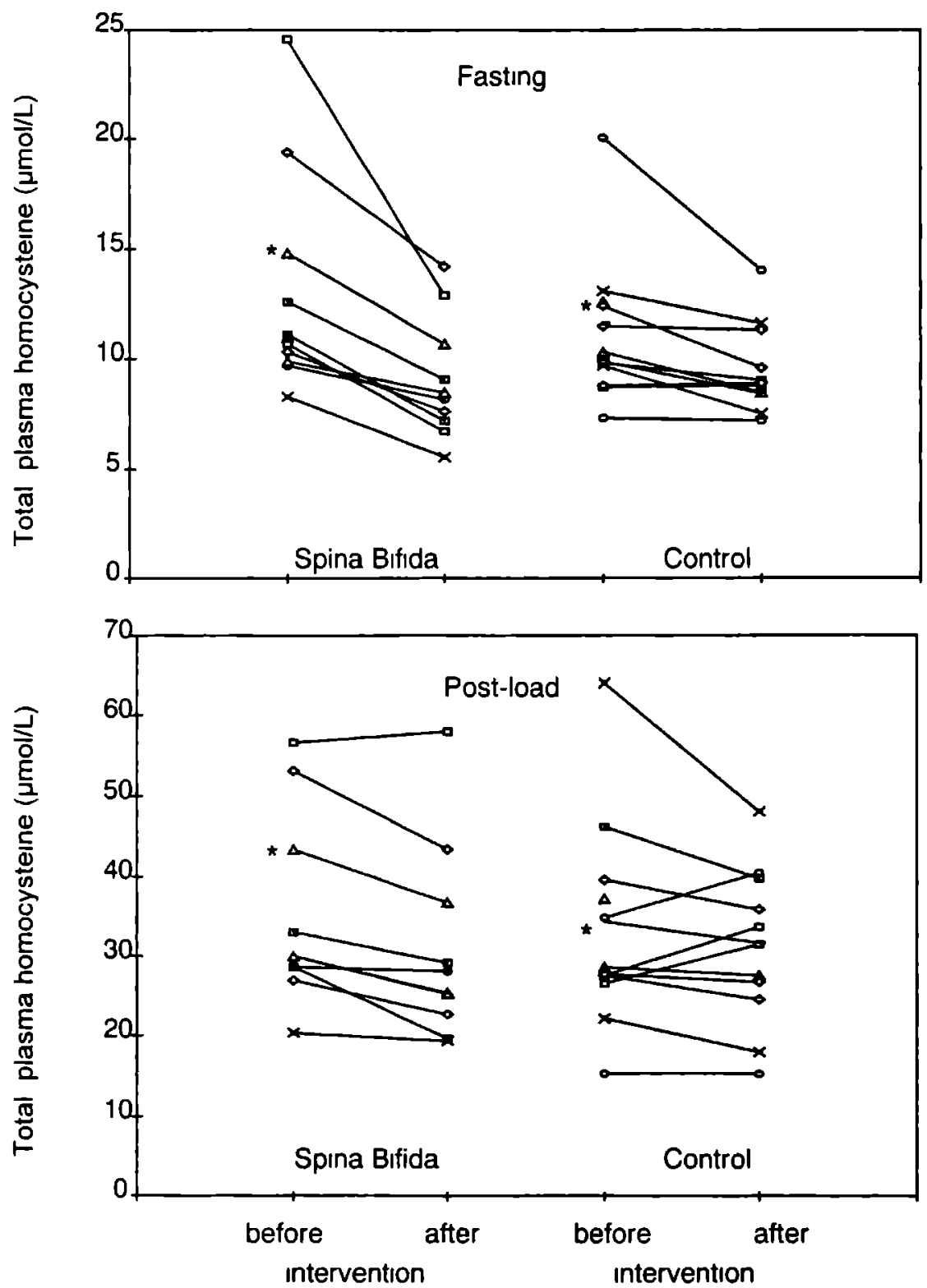

Footnote: Upper panel: Fastıng plasma total homocysteıne concentrations. Lower panel' Plasma total homocysteine concentratıons after methıonıne-loading test. *patients homozygous for the C677T mutation in the gene encoding for methylenetetrahydrofolate reductase. 
Plasma and red blood cell folate concentrations increased significantly during four weeks of intervention with $500 \mu \mathrm{g}$ folic acid per day compared to the placebo period in both the spina bifida and control group (Table 5.2). There were no significant differences in any of the blood parameters between the spina bifida and the control patients. Intervention with folic acid decreased fasting plasma total homocysteine concentrations in the control group $(P<0.01)$ and in the spina bifida patients $(P=$ 0.10) (Table 5.2; Figure 5.1). The same intervention with folic acid significantly decreased post-load plasma total homocysteine concentrations in the spina bifida patients $(P<0.01)$, but not in the control group $(P=0.32)$ (Table 5.2). In those subjects in whom folic acid supplementation did not decrease the high post-load plasma total homocysteine concentrations, it did increase plasma and red blood cell folate concentrations and decreased fasting concentrations of plasma total homocysteine.

One subject in the spina bifida group and one subject in the control group were homozygous for the C677T mutation, which is known to decrease enzyme activity of methylenetetrahydrofolate reductase.

\section{Discussion}

This study aimed at investigating whether spina bifida patients have a derangement in their folate dependent homocysteine metabolism. We could not show any significant difference in the folate status or in plasma total homocysteine concentrations between spina bifida and control patients at baseline. Furthermore, the effects of treatment with $500 \mu \mathrm{g}$ folic acid/d for four weeks on folate status and total homocysteine concentrations were not significantly different between the groups. Four weeks of folic acid supplementation significantly increased plasma folate and red blood cell folate concentrations in spina bifida patients as well as in control subjects. It also decreased plasma total homocysteine concentrations in spina bifida patients and controls. Although not significantly different, the effects of folic acid treatment on both fasting and post-load plasma total homocysteine concentrations were slightly stronger in the spina bifida than the control group (Table 5.2; Figure 5.1). In the presence of a disorder in the homocysteine metabolism, it could be expected that more folic acid would be needed to establish a similar decrease in plasma total homocysteine concentration in spina bifida patients compared to control subjects. Thus, our study gives no indication for such a disorder in spina bifida patients. 
In contrast to our baseline results, van der Put et al. (1997b) and BjørkeMonsen et al. (1997) showed higher fasting plasma total homocysteine concentrations in spina bifida patients than in control subjects. Several investigators studied the folate and vitamin B12 status of foetuses affected with a neural-tube defect. Concordant with our study, none of these studies found significant differences in the folate status between foetuses affected with a neural-tube defect and controls (Bunduki et al., 1995; Economides et al., 1992; Thorand et al., 1996).

Plasma total homocysteine concentrations in the amniotic fluid were shown to be higher in mothers pregnant with a foetus with a neural-tube defect than in control mothers pregnant with a healthy child (Steegers Theunissen et al., 1995). Moreover, vitamin B12 levels in amniotic fluid of pregnancies affected by a neural-tube defect were lower than in healthy pregnancies (Gardiki-Kouidou and Seller, 1997; Weekes et al., 1992). Both the elevated plasma total homocysteine concentrations and the lower vitamin B12 concentrations suggest either a defect in the homocysteine metabolism of mother or child, a transport problem, or leakage of homocysteine from the neural-tube defect into the amniotic fluid. Our study suggests that either a metabolic derangement in the mother, or an abnormality in the transport from mother to child are more important causes for spina bifida than an abnormality in the child itself. Leakage of homocysteine from the neural-tube defect cannot be excluded, but does not explain the more than $50 \%$ of neural-tube defects that can be prevented by intake of folic acid by the mother (Czeizel and Dudás, 1992; MRC Vitamin Study Research Group, 1991).

Van der Put et al. (1995) and Whitehead et al. (1995) showed that the C677T polymorphism in the methylenetetrahydrofolate reductase gene could explain part of the more than $50 \%$ of neural-tube defect cases that can be prevented by the intake of extra folic acid around conception (Czeizel and Dudás, 1992; MRC Vitamin Study Research Group, 1991). This polymorphism was more frequent in patients with a neural-tube defect than in the control population (van der Put et al., 1995; Whitehead et al., 1995). In contrast, in 137 spina bifida patients and 153 control subjects there was no evidence for an association between the frequency of the C677T mutation and the occurrence of spina bifida (Koch et al., 1998). The C677T mutation increases plasma total homocysteine concentrations in patients and control subjects (Bjørke-Monsen et al., 1997; van der Put et al., 1995). Bjørke-Monsen et al. (1997) showed that the difference in elevated fasting plasma total homocysteine was confined to those subjects with one or two mutated $\mathrm{C} \rightarrow \mathrm{T}$ alleles. Only two subjects in our study, one spina bifida patient and one control subject were homozygous for the C677T mutation. We repeated the statistical analyses with exclusion of these 
Chapter 5

subjects. This did not change the results of our study. Our study gives no indications for other differences in the homocysteine metabolism between spina bifida patients and control subjects. However, our small sample size encounters us from drawing firm conclusions.

In conclusion, this study does not show that a derangement in homocysteine metabolism is more frequent in spina bifida patients than in control patients. Moreover, folic acid supplementation seems at least as effective in spina bifida patients as in controls. Therefore, a metabolic derangement in the mother or a defect in the transport of folate from mother to child seem more obvious causes for spina bifida than an abnormality in the homocysteine metabolism of the child itself.

\section{Acknowledgement}

We would like to thank the patients, their families and the staff of the institutes Werkenrode (Groesbeek, the Netherlands) and Het Dorp (Arnhem, the Netherlands). We are grateful to Rob van Dam for his assistance during the field work. We also like to thank the staff of the laboratories for Chemical Endocrinology, Paediatrics and Neurology and Clinical Chemistry of the University Hospital St Radboud in Nijmegen.

This work was supported by Zorg Onderzoek Nederland /Dutch Praeventie Fonds (grant no. 28-2559), The Hague, the Netherlands. Tablets were supplied by Pharmachemie BV, Haarlem, the Netherlands. Abbott Diagnostics, Maidenhead, UK provided the IMx diagnostics kits. 


\section{Dietary folate from vegetables and citrus fruit decreases plasma homocysteine concentrations: a dietary controlled trial}

Ingeborg A Brouwer, Marijke van Dusseldorp, Clive E West, Saskia Meyboom, Chris MG Thomas, Marinus Duran, Karin $\mathrm{H}$ van het Hof, Tom KAB Eskes, Joseph GAJ Hautvast, Régine PM Steegers-Theunissen.

Journal of Nutrition (In Press). 


\section{Abstract}

Elevated plasma total homocysteine concentrations are considered a risk factor for neural-tube defects and cardiovascular disease. Supplementation with folic acid decreases the risk of women having children with neural-tube defects. In both sexes it decreases plasma total homocysteine levels. The present study investigated the efficacy of natural dietary folate in improving folate and homocysteine status. We performed a four-week dietary controlled, parallel design intervention trial with sixtysix healthy subjects (18-45 years) divided into three treatment groups. We supplied daily to each of the groups: the dietary folate group, a diet high in vegetables and citrus fruit (total folate content circa $560 \mu \mathrm{g}$ ) plus a placebo tablet; the folic acid group, a diet naturally low in folate (circa $210 \mu \mathrm{g}$ ) plus folic acid $(500 \mu \mathrm{g}$ folic acid and placebo tablet on alternate days, i.e., $250 \mu \mathrm{g}$ folic acid/d); the placebo group, the same low folate diet plus a placebo tablet. After four weeks of intervention, folate status improved and plasma total homocysteine concentrations decreased in both the dietary folate and the folic acid group. From the amount of additional folate (350 $\mu \mathrm{g} / \mathrm{d})$ and folic acid $(250 \mu \mathrm{g} / \mathrm{d})$ consumed, the relative bioavailability of dietary folate compared to folic acid was, for this experiment, calculated to be 60 to $98 \%$, depending on the endpoint used. In conclusion, increasing the consumption of vegetables and citrus fruit, both good sources of folate, will improve the folate status and decrease plasma total homocysteine concentrations. This may contribute to the prevention of cardiovascular disease and neural-tube defects in the general population. 


\section{Introduction}

Increased intake of folate can have a high impact on public health. Folic acid supplementation around conception decreases the risk of women having offspring with neural-tube defects (Czeizel and Dudás, 1992; MRC Vitamin Study Research Group, 1991). In both men and women folic acid supplementation improves the folate status and decreases elevated plasma total homocysteine concentrations, which are considered to be a risk factor for cardiovascular disease (Boushey et al., 1995) and neural-tube defects (Mills et al., 1995; Steegers Theunissen et al., 1994).

In several countries, women planning to become pregnant are advised to take 400-500 $\mathrm{\mu g}$ of folate per day (Expert Advisory Group, 1992; US Public Health Service, 1992). It is generally thought that this intake can only be reached by using folic acid, the synthetic form of folate. Daily doses of 200-300 $\mathrm{gg}$ of synthetic folic acid improve not only the folate status, but also decrease plasma total homocysteine concentrations (Brouwer et al., 1999; Jacob et al., 1994; O'Keefe et al., 1995; Ward et al., 1997). The effectiveness of these low doses of folic acid suggests that a nutritional intervention with foods rich in folate could also be feasible and successful. We therefore tested the hypothesis that increased intake of dietary folate from vegetables and citrus fruit improves the folate status and decreases plasma total homocysteine concentrations.

\section{Subjects and Methods}

\section{Subjects}

Healthy men and women aged 18-45 years were recruited. A total number of 66 women and 28 men applied for enrolment in the study. Exclusion criteria were: smoking; known gastrointestinal disorders; screening plasma total homocysteine concentrations of $>20 \mu \mathrm{mol} / \mathrm{L}$; or use of vitamins, minerals, yeast or seaweed, malaria prophylactics or anti-convulsants in the four months prior to the experiment. Food products fortified with folic acid are not available in the Netherlands. Therefore, the habitual diet of the subjects contained no folic acid. None of the women were pregnant or planning to become pregnant within the first six months after the study. Based on the selection criteria, 62 women and 25 men were eligible for participation. We included 52 of the women and 25 men into the trial. Ten of these subjects received treatment as part of a study on carotene bioavailability that will be published separately. Because only 77 subjects were required, all 25 men and 52 of the women 
Chapter 6

entered the trial: two women decided not to participate for personal reasons and eight were chosen at random for exclusion. Thus, the present study included 67 subjects. The study was approved by the Medical Ethical Committee of the Division of Human Nutrition and Epidemiology of Wageningen Agricultural University, and all participants gave their written informed consent.

\section{Design}

The trial had a parallel design with three treatments. Group sizes were aimed at showing an $11 \%$ decrease in plasma total homocysteine concentrations after four weeks of intervention with $500 \mu \mathrm{g}$ of folic acid every other day with a power of $80 \%$ (Brouwer et al. 1999). The treatments comprised: firstly, a diet high in natural folate plus a placebo tablet (dietary folate group; $n=23$ ); secondly, a diet low in folate plus supplemental folic acid (folic acid group; $n=22$ ); and thirdly, the same low folate diet plus a placebo tablet (placebo group; $n=22$ ).

All subjects were stratified over the groups for screening concentration of plasma total homocysteine, energy intake, vegetarianism and gender.

\section{Diets}

Before the trial started, trained dieticians estimated the habitual energy intake of the subjects using a validated food frequency questionnaire (Feunekes et al., 1993). This method has been validated for estimating fat and energy intake, however it is not suitable for estimating folate intake. Therefore, we did not estimate habitual folate intake. The energy content of the diets was calculated using the Dutch Nutrient Data Base (Brants and Hulshof, 1995; Stichting NEVO, 1993).

Each day, all subjects received a basal diet with a similar nutrient composition for all groups. Table 6.1 describes the diets, Table 6.2 the nutrient composition. The quantity of the basal diet was based on the habitual energy intake for each subject. Body weights without shoes, jackets, and heavy clothing were recorded twice weekly. The level of energy intake was adjusted when necessary to compensate for any weight change. If subjects complained about having either too much or not enough food we weighed them more often. In exceptional cases, for example when the subjects were hungry or underwent more than usual physical activity, we provided 'energy buns' which had a similar macronutrient composition as the rest of the diet and a known folate content. The meals contained conventional foods and drinks. Six different menus were provided over the four-week intervention period. 
Table 6.1 Six-day cycle menus

\begin{tabular}{|c|c|c|c|c|c|c|}
\hline & DAY 1 & DAY 2 & DAY 3 & DAY 4 & DAY 5 & DAY 6 \\
\hline Basal diet & $\begin{array}{l}\text { whole wheat bread } \\
\text { margarıne } \\
\text { low-fat margarıne } \\
(35 \%) \\
\text { cheese } \\
\text { cheese spread } \\
\text { ham } \\
\text { strawberry jam }\end{array}$ & $\begin{array}{l}\text { whole wheat bread } \\
\text { margarıne } \\
\text { low-fal margarıne } \\
\text { cheese } \\
\text { cheese spread } \\
\text { corned beef } \\
\text { honey }\end{array}$ & $\begin{array}{l}\text { whole wheat bread } \\
\text { margarıne } \\
\text { low-fat margarıne } \\
\text { cheese } \\
\text { cheese spread } \\
\text { ham } \\
\text { sprınkles no chocolate }\end{array}$ & $\begin{array}{l}\text { whole wheat bread } \\
\text { margarıne } \\
\text { low fat margarıne } \\
\text { cheese } \\
\text { cheese spread } \\
\text { minced meat loaf fried } \\
\text { blue berry jam }\end{array}$ & $\begin{array}{l}\text { whole wheal bread } \\
\text { margarıne } \\
\text { low-fat margarıne } \\
\text { cheese } \\
\text { cheese spread } \\
\text { ham } \\
\text { apple syrup }\end{array}$ & $\begin{array}{l}\text { whole wheat bread } \\
\text { margarıne } \\
\text { low fat margarine } \\
\text { cheese } \\
\text { cheese spread } \\
\text { porc fricandeau } \\
\text { cherry jam }\end{array}$ \\
\hline Basal diet & $\begin{array}{l}\text { milk } \\
(\mathrm{egg})^{\star} \\
\text { treacle waffle } \\
\text { apple } \\
\text { free-choice items }\end{array}$ & $\begin{array}{l}\text { milk } \\
\text { (egg)" } \\
\text { spicy biscuit } \\
\text { pear } \\
\text { free-choice items }\end{array}$ & $\begin{array}{l}\text { milk } \\
(\text { egg)* } \\
\text { biscuit } \\
\text { grapes } \\
\text { free-choice items }\end{array}$ & $\begin{array}{l}\text { milk } \\
\text { (egg) } \\
\text { biscult } \\
\text { apple } \\
\text { free-choice items }\end{array}$ & $\begin{array}{l}\text { milk } \\
\text { (egg)* } \\
\text { shortbread biscurt } \\
\text { melon } \\
\text { free-choice items }\end{array}$ & $\begin{array}{l}\text { mılk } \\
(\text { egg) } \\
\text { cracknel } \\
\text { pear } \\
\text { free-choice items }\end{array}$ \\
\hline $\begin{array}{l}\text { Basal dıet } \\
\text { (hot meal) }\end{array}$ & $\begin{array}{l}\text { potatoes } \\
\text { green beans } \\
\text { gravy } \\
\text { beef sausage or } \\
\text { vegetarıan (soja } \\
\text { producl) } \\
\text { curry dressıng } \\
\text { caramel custard }\end{array}$ & $\begin{array}{l}\text { bulgur } \\
\text { vegetable mix } \\
\text { (broccolı, carrot, } \\
\text { cauliflower, corn) } \\
\text { tomato sauce } \\
\text { pork chop or cheese } \\
\text { honey dressing } \\
\text { chocolate custard }\end{array}$ & $\begin{array}{l}\text { pasta } \\
\text { spınach } \\
\text { sour cream } \\
\text { Kromeskı meat filled or } \\
\text { brown beans } \\
\text { tomato dressing } \\
\text { pear/ melon custard }\end{array}$ & $\begin{array}{l}\text { potatoes } \\
\text { peas } \\
\text { sweet-sour sauce } \\
\text { hamburger or } \\
\text { vegetarian (soja } \\
\text { burger) } \\
\text { orange dressıng } \\
\text { rhubarb custard }\end{array}$ & $\begin{array}{l}\text { rice } \\
\text { broccolı } \\
\text { curry sauce } \\
\text { beef } \\
\text { or egg } \\
\text { chives dressıng } \\
\text { vanılla custard }\end{array}$ & $\begin{array}{l}\text { rice } \\
\text { Brussel sprouts } \\
\text { cheese sauce } \\
\text { ham or tahoe } \\
\text { mustard dressing } \\
\text { apple/cinnamon custard }\end{array}$ \\
\hline $\begin{array}{l}\text { Supplement } \\
\text { Dietary folate } \\
\text { group }\end{array}$ & $\begin{array}{l}\text { green beans } \\
\text { salad broccoll/ corn/ } \\
\text { Brussels sprouts } \\
\text { soup spinach } \\
\text { orange juice } \\
\text { clementınes }\end{array}$ & $\begin{array}{l}\text { vegetable mix } \\
\text { salad brocolil/ carrot } \\
\text { ragout peas/ corn/ } \\
\text { carrot } \\
\text { orange juice } \\
\text { orange }\end{array}$ & $\begin{array}{l}\text { spınach } \\
\text { salad green beans/ } \\
\text { onion/ tomato } \\
\text { sowp broccolı } \\
\text { orange juice } \\
\text { clementınes }\end{array}$ & $\begin{array}{l}\text { peas } \\
\text { salad peas/corn/ } \\
\text { pepper } \\
\text { ragout vegetable mix } \\
\text { orange fuice } \\
\text { orange }\end{array}$ & $\begin{array}{l}\text { broccolı } \\
\text { salad broccoli/corn/ } \\
\text { peas } \\
\text { soup vegetable mx } \\
\text { orange juice } \\
\text { clementınes }\end{array}$ & $\begin{array}{l}\text { Brussel sprouts } \\
\text { salad green beans/ } \\
\text { cucumber/ radish } \\
\text { ragout green beans/ } \\
\text { pepper/ onion } \\
\text { orange juice } \\
\text { orange } \\
\end{array}$ \\
\hline $\begin{array}{l}\text { Supplement } \\
\text { Folic acid } \\
\text { group and } \\
\text { Placebo group }\end{array}$ & $\begin{array}{l}\text { salad rice/cucumber } \\
\text { cup-a-soup } \\
\text { pear } \\
\text { grape juice }\end{array}$ & $\begin{array}{l}\text { salad bulgur/celery/ } \\
\text { pepper } \\
\text { cup-a-soup } \\
\text { apple } \\
\text { apple juice }\end{array}$ & $\begin{array}{l}\text { salad pasta/ } \\
\text { cucumber/ pickled } \\
\text { gerkıns/ pepper } \\
\text { curry soup } \\
\text { pear } \\
\text { grape juice }\end{array}$ & $\begin{array}{l}\text { salad rıce/ chıcory/ } \\
\text { apple/ raısıns } \\
\text { cup-a-soup } \\
\text { apple } \\
\text { apple juıce }\end{array}$ & $\begin{array}{l}\text { salad rice/ celery/ } \\
\text { pepper } \\
\text { mushroom ragout } \\
\text { pear } \\
\text { grape juice }\end{array}$ & $\begin{array}{l}\text { salad pasta/ chicory/ } \\
\text { apple/ raisıns } \\
\text { onion soup } \\
\text { apple } \\
\text { apple juice }\end{array}$ \\
\hline
\end{tabular}

¿Eggs were provided once per week Subjects consumed eggs on random days durıng the week (no more than one per day) 
Chapter 6

Table 6.2 Mean daily intake of nutrients and energy durıng dietary intervention period $^{1}$

\begin{tabular}{|c|c|c|c|}
\hline \multirow[t]{2}{*}{ Energy/Nutrient } & \multicolumn{3}{|c|}{ Intervention } \\
\hline & $\begin{array}{c}\text { Dietary folate } \\
\text { group }\end{array}$ & $\begin{array}{c}\text { Folıc acıd } \\
\text { group }^{3}\end{array}$ & $\begin{array}{c}\text { Placebo } \\
\text { group }\end{array}$ \\
\hline \multicolumn{4}{|l|}{ Folate $(\mu g / \text { day })^{2}$} \\
\hline calculated & $594 \pm 27$ & $226 \pm 9$ & $226 \pm 9$ \\
\hline analysed & $560 \pm 184$ & $210 \pm 49$ & $210 \pm 49$ \\
\hline Folıc acid ( $\mu \mathrm{g} /$ day $)$ & 0 & $250^{3}$ & 0 \\
\hline Proteın (energy\%) & 141 & 13.7 & 13.6 \\
\hline Fat (energy\%) & 31.7 & 30.7 & 30.5 \\
\hline Carbohydrates (energy\%) & 53.0 & 55.6 & 55.9 \\
\hline Alcohol (energy\%) & 1.3 & 1.5 & 0.5 \\
\hline Dietary fibre (g/MJ) & 48 & 42 & 41 \\
\hline Energy (MJ/day) & $989 \pm 253$ & $961 \pm 257$ & $9.85 \pm 247$ \\
\hline Energy (kcal/day) & $2364 \pm 605$ & $2297 \pm 614$ & $2354 \pm 590$ \\
\hline
\end{tabular}

'Values are based on the analysis of six complete duplicate diets (one for each day of the menu cycle) plus its calculated contribution from the free choice items (see methods section)

${ }^{2}$ The folate content represents the dally amount for a subject receiving $11 \mathrm{MJ} /$ day. Differences in folate content were similar for all energy levels.

${ }^{3}$ The folıc acıd group recelved one $500 \mu \mathrm{g}$ folıc acıd tablet and one placebo tablet on alternate days. 
In addition to the basal diet (containıng ca $200 \mu \mathrm{g}$ of folate per day by calculation), we supplied subjects in the placebo and folic acid group with foods low in folate (contaınıng ca $25 \mu \mathrm{g} / \mathrm{d}$ by calculation), while the dietary folate group received foods rıch in folate (containıng ca $395 \mu \mathrm{g} / \mathrm{d}$ by calculatıon) (Table 62 ). The main sources of dietary folate were vegetables (spınach, green peas, broccolı, Brussels sprouts, green beans or a mixed vegetable dish, ca $320 \mu \mathrm{g} / \mathrm{d}$ ) and citrus fruit (1 orange or 2 clementines and orange juice, ca $75 \mu \mathrm{g} / \mathrm{d}$ ) Soup or ragout with less vegetables, rice or pasta salad, and non-citrus fruit (apples/pears) instead of citrus fruit were provided to the folic acid and placebo groups The energy content of the foods supplied in addition to the basal diet was simılar for all subjects in all three intervention groups $(1380 \mathrm{~kJ} / \mathrm{d})$

All foodstuffs were weighed out for each subject On weekdays at noon, hot meais were prepared and served under supervision at the Division of Human Nutrition and Epıdemiology If subjects could not finısh their whole meal, dessert was packed and taken home At lunch-tıme, food for the rest of the day was provided and taken home On Friday food for the weekend was taken home Subjects checked whether their own package of food was complete before leaving the Division If the participant later discovered that something was missing it was delivered to their house if subjects could not come to the division to eat their hot meal, food was either collected or delivered to their house in addition to the food supplied, subjects were allowed a limited number of free-choice items low in folate and fat chosen from a list The freechoıce items were maınly non-alcoholıc soft-drınks, alcoholic drınks (subjects were allowed to have no more than one beer each day), candy and sweet bread fillings. All participants kept a diary in which they recorded illness, medication used, consumption of free-choice items, and any deviations from their diet At the end of the trial, subjects were asked to complete an anonymous questıonnaire regardıng problems and noncompliance during the study

Duplicate portions of the low and high folate diet were collected on each of the 29 trial days for a fictitıous participant with a daily energy intake of $11 \mathrm{MJ}$ The folate content was analysed in a sub-sample (one from each menu, in total 12 samples) by microbıological assay with Lactobacillus caseı as described by Horne \& Patterson (Horne and Patterson, 1988) and modified by Tamura, Freeberg \& Cornwell (Tamura et al, 1990) The assay had an intra-assay coefficient of variance (CV) of $<10 \%$. Macronutrients were analysed in pooled samples The energy and nutrient content of the free choice items was estımated from data in food consumption tables (Stichtıng NEVO, 1993) 
Chapter 6

\section{Tablets}

In addition to the food, the folic acid group received a tablet containing $500 \mu \mathrm{g}$ folic acid every other day and a placebo tablet on alternate days, while the other two groups received one placebo tablet daily. Subjects were blind to whether they received folic acid or placebo tablets. Because of the varying amounts of vegetables, participants were aware of their diet category. All subjects noted on a 'tablet calendar' whether they took the tablet or not. Supplementation compliance was monitored by counting the remaining tablets and inspection of the tablet calendars.

\section{Blood sampling and analysis}

Venous blood samples were collected after an overnight fast at the start (days 0 and 1), after two weeks (day 15) and at the end of the intervention period (days 29 and 30 ). Plasma total homocysteine and plasma folate concentrations were assessed in all samples. Red blood cell folate concentrations were determined on days 1 and 30 .

Blood samples were drawn into EDTA vacutainer tubes (Venoject II, Terumo, Madrid, Spain). For the determination of plasma total homocysteine and plasma folate concentration, samples were immediately placed on ice and centrifuged within $60 \mathrm{~min}$ at $3,000 \times g$ for $10 \mathrm{~min}$. Plasma was separated and stored at $-35^{\circ} \mathrm{C}$ for folate determination and at $-80^{\circ} \mathrm{C}$ for total homocysteine determination. For the determination of folate concentrations in red blood cells, whole blood was diluted four-fold with aqueous sodium ascorbate $(10 \mathrm{~g} / \mathrm{L})$ and stored at $-35^{\circ} \mathrm{C}$. Before measurement, the hemolysates were further diluted with IMx Folate RBC Lysis Reagent (Abbott Laboratories, North Chicago, IL, USA). To be able to express the folate concentration in red blood cells, haematocrits were also measured. Correction was made for the concentration of folate in plasma. Plasma total homocysteine was measured by high performance liquid chromatography with fluorimetric detection (Araki and Sako, 1987). The intra- and inter-assay CV were $<8 \%$. Folate concentrations in blood were determined with the Abbott IMx Folic Acid assay, which is based on ion-capture technology for the IMx automated immunoassay system (Abbott Laboratories, North Chicago, IL, USA). The intra-assay CV was $<6 \%$, and the inter-assay CV was $<10 \%$. All samples from each subject were analysed in the same run.

\section{Calculations of bioavailability of folic acid}

We calculated the bioavailability of dietary folate from vegetables and citrus fruits relative to the bioavailability of folic acid. For each endpoint (change in concentration of plasma folate, red blood cell folate and plasma total homocysteine), it was calculated as follows: 


$\begin{array}{rll}\text { Relative bioavailability }(\%)= & \begin{array}{l}\text { Change in endpoint in } \\ \text { dietary folate group } \\ \text { during intervention } \\ \text { minus change in } \\ \text { placebo group }\end{array} \\ \begin{array}{ll}\text { Change in endpoint in } \\ \text { folic acid group } \\ \text { during intervention } \\ \text { minus change in } \\ \text { placebo group }\end{array} & \begin{array}{l}\text { Additional } \\ \text { folic acid } \\ \text { provided } \\ (250 \mu g)\end{array} \\ & \begin{array}{l}\text { Additional } \\ \text { dietary } \\ \text { folate } \\ \text { provided } \\ (\mu g)\end{array}\end{array}$

For each subject, average values for plasma total homocysteine and plasma folate concentration were taken for day 0 and day 1 (week 0 ), and for day 29 and day 30 (week 4). Response to the various treatments was calculated for each subject as the change in each endpoint, between the start (week 0 ) and the end (week 4) of the intervention period.

\section{Statistics}

Changes in folate and total homocysteine concentrations were normally distributed as checked by visual inspection of the normal probability plots (univariate procedure; SAS Institute Inc, Cary, NC). To analyse differences in endpoint response between the intervention groups and the placebo group, Student t-tests were used with a significance level of $P<0.025$ to maintain an overall significance level of $P<0.05$. One-way ANOVA was used to analyse differences in baseline levels of plasma total homocysteine, plasma folate and red blood cell folate concentrations among the three groups.

\section{Results}

\section{Diets and adherence}

The nutrient and energy intakes of the subjects are shown in Table 6.1. The energy intake from the free-choice items was fixed for each level of daily energy intake and was on average $11.2 \% \pm 1.3$ (SD) of total energy.

Neither the questionnaires, nor the diaries revealed any deviations from the protocol that might have affected the results. Two subjects missed three supervised hot meals, six subjects two supervised meals, and 16 subjects missed one supervised meal. In all these cases the meals were eaten outside the division. The remaining 42 
Chapter 6

subjects attended all supervised hot meals. One man withdrew from the study on the second day because he could not adhere to the diet.

Counting of the remaining tablets and checking the tablet calendars revealed that seven subjects in the folic acid group failed to take one tablet during the intervention period. None of the subjects failed to take more than one folic acid tablet during the study.

Stratification was successful because plasma total homocysteine, energy intake, vegetarianism and gender were not different among the groups. The mean age $\pm S D$ was $23.0 \pm 7.5$ years and their body mass index was $22.4 \pm 2.0 \mathrm{~kg} / \mathrm{m}^{2}$. Over the 29 days of the trial, body weights decreased by $0.6 \pm 0.9 \mathrm{~kg}$ (mean \pm SD).

\section{Folate status}

Baseline plasma folate and red blood cell folate concentrations were not significantly different among the three groups. After four weeks of intervention, the plasma folate concentrations increased in both the dietary folate and the folic acid group (Table 6.3). The most distinct increase in plasma folate concentrations occurred during the first two weeks. Red blood cell folate concentrations also increased in both the dietary folate group and the folic acid group (Table 6.3).

\section{Homocysteine}

At baseline, the median $(25 \%, 75 \%)$ of the plasma total homocysteine concentration was $10.1(8.0,11.6) \mu \mathrm{mol} / \mathrm{L}$. Baseline plasma total homocysteine concentrations were not significantly different among the groups. Four weeks of intervention decreased the plasma total homocysteine concentrations in both the dietary folate and the folic acid group (Table 6.3). After correction for changes in the placebo group, the mean decrease was $2.0 \mu \mathrm{mol} / \mathrm{L}(95 \% \mathrm{Cl}, 1.0$ to 3.0$)$ in the dietary folate group and 2.4 $\mu \mathrm{mol} / \mathrm{L}$ (1.4 to 3.4 ) in the folic acid group. Plasma total homocysteine concentrations decreased gradually during the entire four-week intervention period (Table 6.3).

\section{Bioavailability}

The bioavailability of folate from vegetables and citrus fruits relative to folic acid was for the different endpoints: $60 \%$ based on plasma total homocysteine concentration; $78 \%$ based on plasma folate concentration; and $98 \%$ based on red blood cell folate concentration. 
Table 6.3 Effect of dietary folate and folic acid on plasma folate, red blood cell folate and total plasma homocysteine concentrations.

\begin{tabular}{|c|c|c|c|}
\hline & $\begin{array}{l}\text { Dietary folate group } \\
\text { (additional folate: } \\
\begin{array}{c}350 \mu \mathrm{g} / \mathrm{d}) \\
(\mathrm{n}=23)^{\prime}\end{array}\end{array}$ & $\begin{array}{l}\text { Folic acid group } \\
\text { (additional folic acid: } \\
500 \mu g / 2 d) \\
(n=22)\end{array}$ & $\begin{array}{c}\text { Placebo group } \\
\text { (additional folate / folic acid: } 0 \\
\mu \mathrm{g} / \mathrm{d}) \\
(\mathrm{n}=22)\end{array}$ \\
\hline \multicolumn{4}{|l|}{ Plasma folate $(\mathrm{nmol} / \mathrm{L})$} \\
\hline Week $0^{2}$ & $12.8(11.8$ to 16.2$)$ & $13.5(11.0$ to 16.4$)$ & $12.7(10.2$ to 16.1$)$ \\
\hline Week $2^{2}$ & $19.8(17.7$ to 23.3$)$ & $17.2(16.3$ to 21.7$)$ & 11.7 (10.0 to 15.9$)$ \\
\hline Week $4^{2}$ & $19.4(18.3$ to 23.0$)$ & $19.8(17.8$ to 22.5$)$ & $12.4(10.4$ to 14.6$)$ \\
\hline Change from baseline ${ }^{3}$ & $7.0(5.4 \text { to } 8.6)^{\star \star}$ & $6.4(4.7 \text { to } 8.0)^{\star \star}$ & \\
\hline \multicolumn{4}{|c|}{ Red blood cell folate (nmol/L) } \\
\hline Week $0^{2}$ & 336 (268 to 386$)$ & $328(285$ to 370$)$ & 353 (283 to 403$)$ \\
\hline Week $4^{2}$ & 367 (320 to 447$)$ & 379 (338 to 418$)$ & 334 (299 to 411) \\
\hline Change from baseline ${ }^{3}$ & $60.5(31.1 \text { to } 89.9)^{\star \star}$ & $44.1(14.7 \text { to } 73.4)^{*}$ & \\
\hline
\end{tabular}




\begin{tabular}{ccc}
$\begin{array}{c}\text { Dietary folate group } \\
\text { (additional folate }\end{array}$ & $\begin{array}{c}\text { Folic acid group } \\
\text { (additıonal folic acıd }\end{array}$ & $\begin{array}{c}\text { Placebo group } \\
\text { (additional folate / folic acid } 0\end{array}$ \\
$350 \mu \mathrm{g} / \mathrm{d})$ & $500 \mu \mathrm{g} / 2 \mathrm{~d})$ & $\mu \mathrm{g} / \mathrm{d})$ \\
$(\mathrm{n}=23)^{\prime}$ & $(\mathrm{n}=22)$ & $(\mathrm{n}=22)$ \\
\hline
\end{tabular}

Plasma homocysteıne $(\mu \mathrm{mol} / \mathrm{L})$

\begin{tabular}{|c|c|c|c|}
\hline Week $0^{2}$ & $96(84$ to 114$)$ & $100(83$ to 121$)$ & $104(79$ to 117$)$ \\
\hline Week $2^{2}$ & $90(80$ to 100$)$ & 91 (74 to 103$)$ & $99(76$ to 115$)$ \\
\hline Week $4^{2}$ & 84 (79 to 98$)$ & $88(74$ to 100$)$ & $102(85$ to 121$)$ \\
\hline Change from baselıne ${ }^{3}$ & $-20(-30 \text { to }-10)^{\star \star}$ & $-24(-34 \text { to }-14)^{\star \star}$ & \\
\hline
\end{tabular}

' One of the subjects withdrew from the study after two days of intervention

${ }^{2}$ Median $(25 \%, 75 \%)$

${ }^{3}$ Mean ( $\mathrm{n}=22 \%$ confidence interval) change in intervention group ( $\left.n=22\right)$ over 4-week period corrected for change in placebo group $(n=22)$ The data are presented as medians for absolute values and means for changes because changes, but not absolute values are normally distributed Student t-test ${ }^{\star} P<001,{ }^{\star \star} P<0001$ 


\section{Discussion}

This controlled dietary intervention study demonstrates that a diet rich in vegetables and citrus fruit favourably affects plasma folate, red blood cell folate and plasma total homocysteine concentrations in young healthy volunteers. Many studies have shown that folic acid, the synthetic monoglutamate, decreases plasma total homocysteine concentrations and improves the folate status (Brouwer et al., 1999; Cuskelly et al., 1996; Jacob et al., 1994; O'Keefe et al., 1995; Ward et al., 1997). However, studies investigating the effects of natural food folate on plasma total homocysteine and folate status are scarce. A cross-sectional study showed that intake of dietary folate was inversely correlated with plasma total homocysteine concentrations and positively correlated with the plasma folate concentration (Tucker et al., 1996). Cuskelly et al. (1996) found a non-significant increase of $11 \%(95 \% \mathrm{Cl}$ : $-6,29)$ in red blood cell folate concentration in young healthy women after three months of intervention with natural food folate. Our study shows a significant $17 \%(\mathrm{Cl}$ : 8 to 26) increase in red blood cell folate concentration after four weeks of intervention (Table 6.3). This discrepancy can be explained by differences in the study hypotheses and designs. Cuskelly et al. (1996) investigated whether fortified foods, supplements and consumption of natural food folate would have equal effects on folate status in a free living situation, in which the subjects selected their own foods. They included 10 women in each group and the average intake of additional dietary folate was calculated to be $200 \mu \mathrm{g}$ per day (Cuskelly et al., 1996). In contrast, our study was a controlled dietary intervention study with 22 subjects in each group. We supplied the subjects in the dietary folate group with vegetables and fruits containing $350 \mu \mathrm{g}$ of additional dietary folate per day, a relatively high amount. Nevertheless, because their study lasted three times longer than ours a higher response would have been expected in the study of Cuskelly et al. (1996).

The $350 \mu \mathrm{g}$ of additional dietary folate consumed daily in the dietary folate group was 1.4 times the $250 \mu \mathrm{g}$ of folic acid provided to subjects in the folic acid group. Depending on the endpoint chosen, the bioavailability of dietary folate, from vegetables and citrus fruit, relative to folic acid was calculated to be between $60 \%$ and $98 \%$. This estimate is higher than the $50 \%$ or less suggested by the study of Sauberlich et al. (1987) who determined bioavailability of folate from a mixed diet by using responses in plasma folate. Based on the response in red blood cell folate concentration our estimate of relative folate bioavailability of $98 \%$ is high compared to the $39 \%$ estimated from the study of Cuskelly et al. (1996). The differences in bioavailability between the 
studies might be explained by the fact that we used only vegetables and citrus fruit as a source of folate, while the other two studies fed a wider range of food products (Cuskelly et al, 1996, Sauberlıch et al, 1987) However, the difference might also be attributable to the higher degree of compliance in fruit and vegetables consumption in our study

In our study the relative bioavailability is consıderably lower when calculated from the change in plasma total homocysteıne $(60 \%)$ than from the change in folate concentrations in plasma (78\%) and red blood cells $(98 \%)$ These differences cannot be explained by differences in intestınal absorption between synthetıc folic acid and folate from foods, but would appear to be related to the chemical form of the vitamın ingested Tablets contain the fully oxidised form of pteroylglutamic acid while in food, the vitamın exists with two or four additional hydrogen atoms and is conjugated to glutamic acid Food folate appears to be less effective in reducing plasma total homocysteine concentrations than folic acid On the other hand, it tends to accumulate more in red blood cells than in plasma

For practical reasons we provided $500 \mu \mathrm{g}$ of folic acıd on alternate days Instead of $250 \mu \mathrm{g}$ each day it cannot be ruled out that the estımate of bıoavallability based on changes in plasma total homocysteine $(60 \%)$ would have been slightly lower if we had provided $250 \mu \mathrm{g}$ of folic acid each day, because Kelly et al (1997) have shown that an intake of folıc acid in addition to that in the diet of more than 266 $\mu \mathrm{g} / \mathrm{d}$ results in significant amounts of unmetabolised folic acid in the blood (Kelly et al, 1997) This suggests that not all folic acid supplied is available for the remethylation of homocysteıne to methionıne

Folate is the nutrient most likely to be responsible for the reduction in plasma total homocysteine concentrations because it was present in large quantities in the diet of the dietary folate group and because folate concentrations in plasma and red blood cells increased significantly durıng the intervention perıod in additıon to folate, vitamın B12 is also involved as a co-factor in the remethylation process However, vitamın B12 is only present in animal products and therefore could not have caused the observed reduction in plasma total homocysteıne concentrations in our study Apart from the remethylation to methionıne, homocysteine can also be converted to cysteine by transsulfuration by the vitamın B6-dependent enzyme cystathionıne synthase Even though vitamın B6 is present in vegetables and fruit and even though an intake of vitamın $\mathrm{B} 6$ above the recommended dally allowances might protect women against coronary heart disease (Aimm et al , 1998), it is not likely to have caused the observed effect on fasting plasma total homocysteıne Vitamın $\mathbf{B 6}$ administration in tablet form has been shown to have a marked effect on plasma total homocysteine concentrations 
after methionine loading, while the effect of vitamin B6 administration on fasting plasma total homocysteine concentrations is regarded as negligible (Ubbink et al., 1994).

This study was designed to determine the efficacy of dietary folate from vegetables and citrus fruit to improve the folate status and to decrease plasma total homocysteine concentrations. Therefore, we chose the strategy of supplying the subjects with a high amount of folate in a controlled setting rather than to examine the effects that can be observed under field conditions. As a consequence, the intake of $350 \mathrm{~g}$ of vegetables and one piece of citrus fruit and $200 \mathrm{~mL}$ of citrus fruit juice given in our study in addition to the basal diet (total folate content in the dietary folate group: $560 \mu \mathrm{g} / \mathrm{d}$ ) is higher than what can be expected to be eaten by the general population.

In summary, we have shown that the intake of folate-dense vegetables and citrus fruit significantly enhances the folate status and decreases plasma total homocysteine concentrations in healthy volunteers. 


\section{Acknowledgement}

The authors wish to thank the volunteers for their participation and Ms E Siebelink, Ms C Schuurman, Ms J Dijkstra, Ms D Boonstra, Ms M Jimmink and Ms $N$ de Bock for their assistance during the intervention study. We are grateful to Dr J Selhub, Ms M Nadeau and Ms H Elzerman (Jean Mayer USDA Human Nutrition Research Center on Aging at Tufts University, Boston, USA) for measuring folate in the duplicate portions. We thank Dr A Passas, Abbott Diagnostics, Maidenhaid, UK, for his support concerning the IMx diagnostic testing kits. We also thank Mr E Haddeman, Unilever Research Vlaardingen, for his support. Finally, we thank the laboratory staff of the Division of Human Nutrition and Epidemiology of the Wageningen Agricultural University, the Department of Chemical Endocrinology of the University Hospital Nijmegen St Radboud and the Laboratory of Metabolic Diseases of the Wilhelmina Children's Hospital in Utrecht for their support and expert technical assistance.

This work was supported by the Zorg Onderzoek Nederland / Dutch Prevention Fund (28-2559), The Hague, and Unilever Research Vlaardingen. Tablets were supplied by Pharmachemie BV, Haarlem, the Netherlands. Abbott Diagnostics, Maidenhead, UK provided the IMx diagnostic kits. 


\section{Bioavailability of folate and folic acid: Review of the literature}

Ingeborg A Brouwer, M van Dusseldorp, Clive E West, Régine PM SteegersTheunissen. 


\section{Introduction}

Folate is a B-vitamın that serves as a methyl group donor in one-carbon metabolism. The term folate refers to all derivatives with the biological activity of pteroylmonoglutamic acid (folic acid). Folic acid is the synthetic fully oxidised monoglutamate of the vitamın that is not present in significant quantities in nature. In nature, various reduced forms of folate with one or more glutamate groups occur (see Figure 12 ).

During the last decade, folic acid has received much attention because new functions apart from those related to the classical treatment of megaloblastic anaemia have been discovered Folic acid supplementation around the time of conception has been proven to make a contribution to the prevention of neural-tube defects (Czeizel and Dudás, 1992, MRC Vitamın Study Research Group, 1991). The Federal Government of the USA responded to these findings by mandating food producers to fortify grain products with folic acid. This stresses the importance of understanding the factors which affect bioavallability of folic acid added to foods.

Furthermore, dietary folate and folic acid both effectively decrease total homocysteine levels in plasma (Brouwer et al., 1999; Homocysteine Lowering Trialists' Collaboration, 1998, Chapter 6). This is important because an elevated plasma homocysteıne concentration has been identified as an independent risk factor for cardiovascular disease (Boushey et al, 1995; Graham et al, 1997) Plasma homocysteine concentration can be regarded as a functional indicator of the folate status (Jacob et al , 1995)

This review will discuss the factors influencing bioavailability of natural food folate and of folic acid from fortified food products it also includes discussion of the efficacy of folate and folic acıd in decreasing plasma homocysteıne levels.

\section{Intestinal absorption}

Dietary folates are a mixture of various pteroylpolyglutamates (PteGlun $)$. These pteroylpolyglutamates have between 2 and 7 glutamate residues in their side chain. Before absorption, which takes place in the jejunum, dietary polyglutamyl folates must first be deconjugated by the enzyme pteroylpolyglutamate hydrolase (folate conjugase) to a monoglutamyl form (PteGlu $_{1}$ )

Before the fully oxidısed monoglutamyl form (PteGlu $)_{1}$ ) of the vitamın, folic acid, enters the portal circulation it is reduced to tetrahydrofolate $\left(\mathrm{H}_{4} \mathrm{PteGlu}_{1}\right)$ This form is etther methylated or formylated in the mucosal cells of the jejunum (Perry and 
Chanarın, 1973; Selhub et al., 1973; Selhub et al., 1983; Strum, 1979). However, when single doses of more than $266 \mu \mathrm{g}$ of folic acid have been fed, unmetabolised folıc acıd has been shown to be present in serum (Kelly et al., 1997).

\section{Definition of bioavailability}

In pharmacokinetics bıoavallability is described as the ratio of area under the curve derived from an oral dose to the area under the curve derived from an intravenous reference dose (Rowland and Tozer, 1989). However, this definition is not valid in folate bioavailability because it requires that the total clearance is independent of the route of administration. This is not the case for folates (Gregory et al., 1992). Rogers et al showed that for that reason administration of folate via the same route is preferred in folate bıoavaılability studies (Rogers et al., 1997) Most studies in the field of folate determıned relative instead of absolute bıoavallabılity. In those studies bıoavallabılity of the compound is assessed relatıve to the bıoavailability of folic acid, the fully oxidised monoglutamate (PteGlu, ).

At the Bıoavallabılity meetıng held in Wagenıngen in May 1997, bioavailability was defined as the fraction of an ingested nutrient which has the potential to meet functional demands in target tissues. This definıtion implies that bioavailability refers to post-absorptive processes, namely bioefficacy and biodelivery, as well as absorption (Strain and West, 1999). Plasma total homocysteine is a functional parameter of folate status. Therefore, changes in plasma total homocysteine can be used as a measurement of bioefficacy according to this definition. Changes in plasma folate or red blood cell folate can be regarded as measurements of bıodelivery. In this review, bıoavailability covers measurements of absorption, biodelivery and bioefficacy.

\section{Factors influencing folate and folic acid bioavallability: SLAMENGHI}

In 1996 de Pee \& West published a review on dietary carotenoids and their role in combating vitamın A deficiency They introduced the mnemonic 'SLAMANGHI' to order the factors influencing the bioavarlability of carotenoids (de Pee and West, 1996). Durıng the Wagenıngen Bıavaılabılity meetıng the word was modified to SLAMENGHI. The SLAMENGHI factors are not specifıc for carotenoid bioavallability, but can also be applied to the bioavallability of other nutrients. In this review we will discuss the factors influencing bioavailability of folate with reference to SLAMENGHI: Species of folate; Lيnkage at molecular level; Amount of folate/folic acid consumed; Matrix; Effect modifiers; Nutrient status; Genetic factors; Host-related factors; Mathematical Interactions between the various factors. 


\section{Species of folate}

In this section, the effects of different species of folate on bioavallability will be discussed Folate occurs in many different forms Folic acid (PteGlu $)_{1}$, which only exists in small amounts in nature, is the fuily oxıdised monoglutamate of the vitamin and does not have moieties which can be transferred as one-carbon units The more reduced forms of folate, dihydrofolate and tetrahydrofolate, which do exist in nature, can be substituted with such moieties (Wagner, 1995) These reduced forms, for example 5-methyltetrahydrofolate and formyltetrahydrofolates are much more common in nature (Fıgure 12 )

The bioavallability of oxidised and reduced folates with or without various onecarbon units has been investigated in a series of human intervention studies (Table 71 ) Findıngs from these studies are not consistent Perry \& Chanarın found a greater increase in serum folate levels after ingestion of reduced folates than after ingestion of folic acid However, urinary excretion of folic acid was higher than that of the other monoglutamyl folate forms (Perry and Chanarin, 1970) Brown et al (1973) found that the bioavallability of other monoglutamate forms was greater than that of folic acid except that the bioavailability of 5-formyltetrahydrofolate was sımılar and of tetrahydrofolate was less (Brown et al , 1973) On the basıs of a study using the ratio of urınary excretıon of orally admınıstered folate labelled with [ $\left.{ }^{2} \mathrm{H}_{2}\right]$ and intravenously administered folate labelled with $\left[{ }^{2} \mathrm{H}_{4}\right]$, Gregory et al (1992) concluded that folic acid was more bioavallable than the reduced forms of the vitamın Other studies have found no differences in bioavallability between folic acid and the reduced forms (Bhandarı and Gregory, 1992, Pietrzik and Remer, 1989, Tamura and Stokstad, 1973)

One problem with most studies investigating folate bioavalability is that the variation in response between subjects can be quite substantial Another problem is that it is not possible to determıne whether these differences are due to differences in absorption or in postabsorption processes in all studies, except that of Pietrzik and Remer (1989), subjects received one or more doses of folıc acıd for periods up to seven days in order to saturate the tissues with folic acid

To our knowledge, there are no studies publıshed investigatıng the effect of different species of folate on plasma total homocysteıne concentratıons 
Table 7.1 Effect of Species of folate on folate bioavallabılity (human intervention studies)

\begin{tabular}{|c|c|c|c|}
\hline Authors & Design & Results & Conclusions and comments \\
\hline $\begin{array}{l}\text { Perry \& } \\
\text { Chanarın, } \\
1970\end{array}$ & 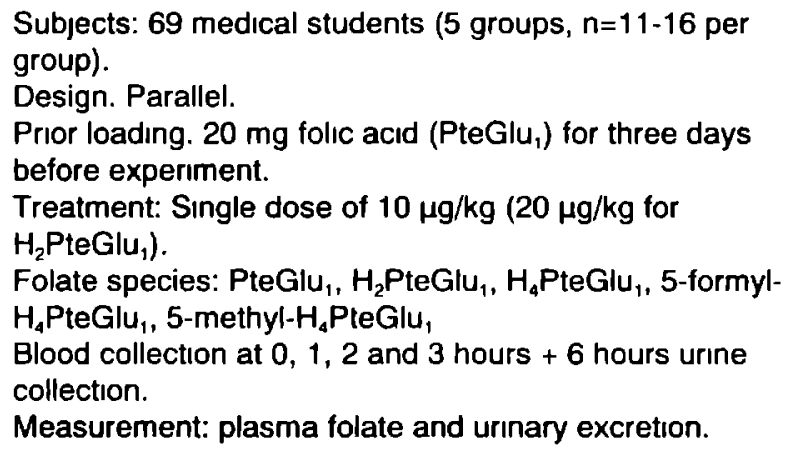 & 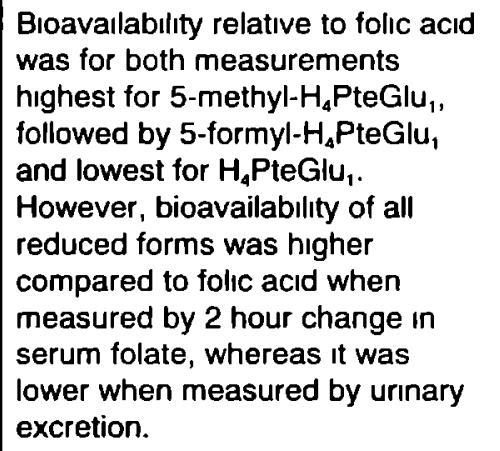 & $\begin{array}{l}\text { This study suggests that } \\
\text { differences exist between the } \\
\text { several monoglutamyl forms of } \\
\text { folate. However, the short duration } \\
\text { of the measurement period ( } 6 \\
\text { hours urine collection and } 3 \text { hours } \\
\text { blood collection) might not be long } \\
\text { enough to measure true } \\
\text { differences in study. }\end{array}$ \\
\hline $\begin{array}{l}\text { Brown et al., } \\
1973\end{array}$ & 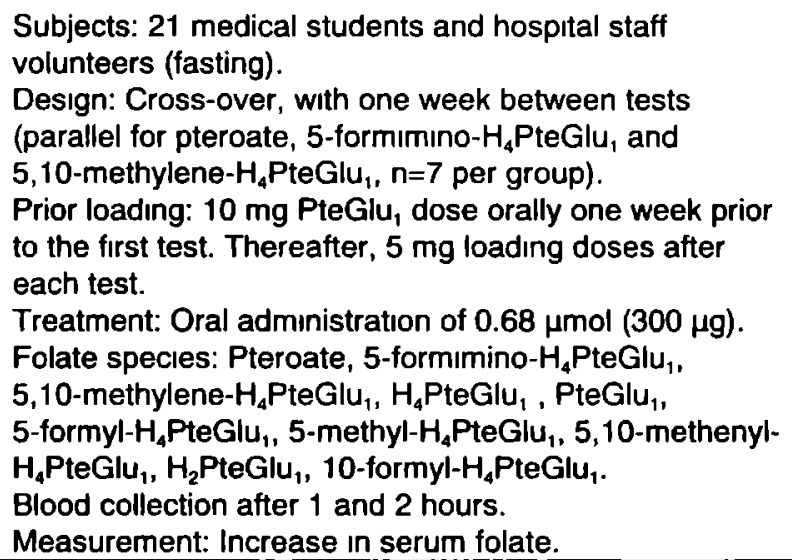 & 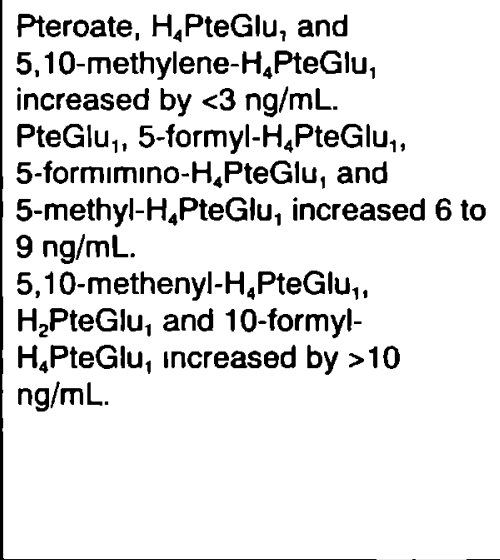 & $\begin{array}{l}\text { This study suggests that the } \\
\text { varıous monoglutamyl forms of } \\
\text { folate have different bioavallability. } \\
\text { However, the short duration of the } \\
\text { serum collection might also be } \\
\text { due to differences in absorption } \\
\text { time. }\end{array}$ \\
\hline
\end{tabular}




\begin{tabular}{|c|c|c|c|}
\hline Authors & Design & Results & Conclusions and comments \\
\hline $\begin{array}{l}\text { Tamura \& } \\
\text { Stokstad, } \\
1973\end{array}$ & 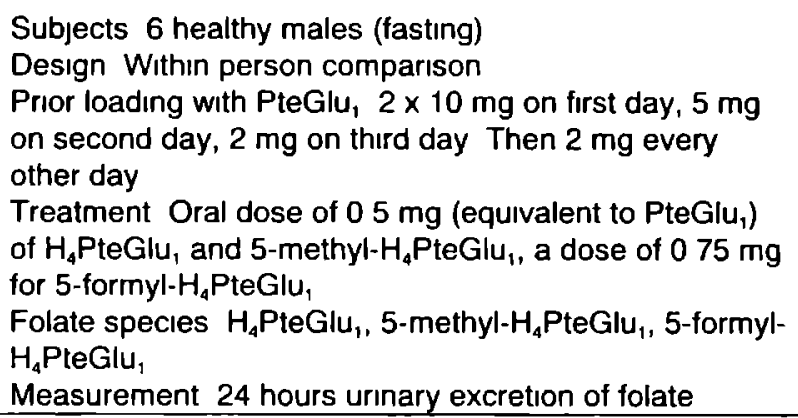 & $\begin{array}{l}\text { Folate bioavallability compared to } \\
\text { PteGlu, } \\
\left.\mathrm{H}_{4} \text { PteGlu, } 1047 \% \text { (range } 40-136\right) \\
(n=6) \\
5-\text { methyl-H }{ }_{4} \text { PteGlu, } 1208 \%(82- \\
152)(n=6) \\
5-\text { formyl-H }{ }_{4} \text { PteGlu, } 700 \%(64-76) \\
(n=2)\end{array}$ & $\begin{array}{l}\text { No signiticant difference in relative } \\
\text { bioavallability between } \mathrm{H}_{4} \mathrm{PteGlu} \text {, } \\
5 \text {-formyl- }{ }_{4} \text { PteGlu }{ }_{1} \text { and } 5 \text {-methyl- } \\
\mathrm{H}_{4} \text { PteGlu, compared to PteGlu } \\
\text { There was a wide variation in } \\
\text { response between subjects }\end{array}$ \\
\hline $\begin{array}{l}\text { Pietrzik \& } \\
\text { Remer, } 1989\end{array}$ & $\begin{array}{l}\text { Subjects } 12 \text { healthy adults } \\
\text { Design Cross-over with one week between tests } \\
\text { No prior loading } \\
\text { Treatment Single dose of } 1 \mathrm{mg} 5 \text {-formyl-H }{ }_{4} \text { PteGlu or } \\
\text { PteGlu } \\
\text { Folate species } 5 \text {-formyl- } \mathrm{H}_{4} \mathrm{PteGlu} \text { versus PteGlu } \\
\text { Measurement Area under the curve (AUC) for serum } \\
\text { folate ( } 3 \text { days) }\end{array}$ & $\begin{array}{l}\text { The ratio for } A \cup C \text { for PteGlu } \\
\text { versus } 5 \text { formyl- } H_{4} \text { PteGlu, was } \\
102\end{array}$ & $\begin{array}{l}\text { This study suggests a similar } \\
\text { bioavallability for PteGlu, and 5- } \\
\text { formyl- } \mathrm{H}_{4} \text { PteGlu, in aqueous } \\
\text { solution }\end{array}$ \\
\hline $\begin{array}{l}\text { Gregory III et } \\
\text { al , } 1992\end{array}$ & 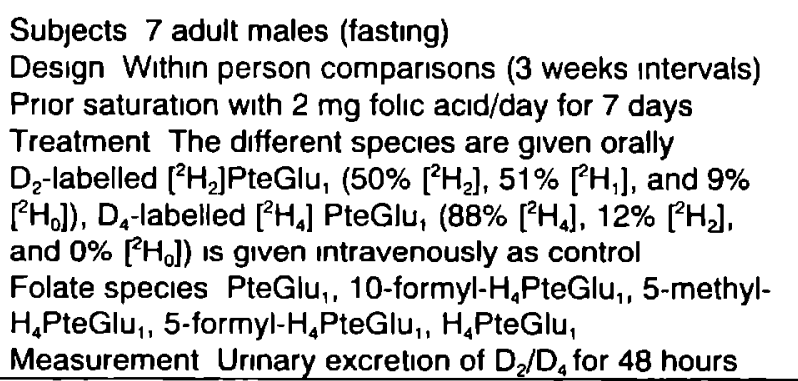 & $\begin{array}{ll}\text { Urınary } \mathrm{D}_{2} / \mathrm{D}_{4} \text { excretion ratıos } \\
\text { PteGlu } 153 \\
\text { 10-formyl-H }{ }_{4} \text { PteGlu, } \\
\text { 5-methyl- } \mathrm{H}_{4} \text { PteGlu, } & 102 \\
\text { 5-formyl-H }{ }_{4} \text { PteGlu, } & 099 \\
\mathrm{H}_{4} \text { PteGlu, } & 113 \\
& 071\end{array}$ & $\begin{array}{l}\text { This study indicates that } \\
\text { differences in bioavailability of } \\
\text { monoglutamyl folates exist } \\
\text { Bioavallability of folic acid seems } \\
\text { better than of the reduced forms }\end{array}$ \\
\hline
\end{tabular}




\section{Linkage at molecular level}

Folate not only occurs as different species as discussed above but also with more than one glutamate residue in this section, bioavailability of folate with different numbers of glutamate residues in its side chain (PteGlu $n, n=1-7$ ) in human volunteers will be discussed (Table 72 )

As discussed above, pteroylpolyglutamates which are the major forms of folate in foods, have first to be hydrolysed to monoglutamates before absorption in the small intestıne can take place A conjugase present in the jejunum is responsible for removing glutamate residues from pteroylpolyglutamates (Reisenauer et al, 1977) Under normal circumstances, the activity of this folate conjugase enzyme is not rate limiting in the absorption process (Reisenauer and Halsted, 1987) This finding is in line with that from earlier studies using ${ }^{3} \mathrm{H}$-labelled PteGlu PteGlu ${ }_{7}$ is absorbed nearly as well as PteGlu, (Godwin and Rosenberg, 1975, Rosenberg and Godwin, 1971) Two studies usıng 24 hour urinary excretıon of folate and area under the curve of serum folate also found no significant differences in bioavailability of PteGlu, PteGlu 3 and PteGlu (Balley et al, 1988, Tamura and Stokstad, 1973) However, a well designed study using labelled folates suggested that PteGlu is less bioavailable than PteGlu, (Gregory et al, 1991) Earlier studies also suggested that less PteGlu, disappeared from the jejunum than PteGlu, (Halsted et al, 1975, Halsted et al, 1978) Although the results of the studies are not equivocal, absorption of PteGlu $n$ is often found to be less than that of PteGlu, This may imply that bıoavallability of polyglutamates is less than that of monoglutamates However, it cannot be excluded that uptake of polyglutamates takes longer, but that the net effect in the long-term is similar to monoglutamates 
Table 7.2 Effect of Lınkage at molecular level, pteroylglutamate chaın length, on folate bıoavallabılity (human interventıon studies)

\begin{tabular}{|c|c|c|c|}
\hline Authors & Design & Results & Conclusions and comments \\
\hline $\begin{array}{l}\text { Tamura \& } \\
\text { Stokstad, } \\
1973\end{array}$ & $\begin{array}{l}\text { Subjects } 6 \text { healthy males (fasting) } \\
\text { Desıgn Withın person comparıson } \\
\text { Prior loading with PteGlu, } 2 \times 10 \mathrm{mg} \text { on first day, } 5 \mathrm{mg} \\
\text { on second day, } 2 \mathrm{mg} \text { on third day Then } 2 \mathrm{mg} \text { every } \\
\text { other day for the duration of the study } \\
\text { Treatment Oral dose of } 075 \text { - } 20 \mathrm{mg} \text { equivalent to } \\
\text { PteGlu, } \\
\text { Chain length PteGlu } \\
\text { Measurement } 24 \text { hours urinary excretion of folate }\end{array}$ & $\begin{array}{l}\text { Folate availability compared to } \\
\text { PteGlu, } \\
\text { PteGlu } 852 \% \text { (range } 27-144) \\
\text { (n=6) } \\
\text { PteGlu, } 904 \%(13-140)(n=14)\end{array}$ & $\begin{array}{l}\text { No significant differences in relative } \\
\text { bioavailability between PteGlu } \\
\text { PteGlu, } \\
\text { There was a wide varıation in } \\
\text { response between the subjects }\end{array}$ \\
\hline $\begin{array}{l}\text { Godwın \& } \\
\text { Posenberg, } \\
1975\end{array}$ & $\begin{array}{l}\text { Subjects } 11 \text { healthy fastıng volunteers ( } 4 \text { men, } 7 \\
\text { women) } \\
\text { Desıgn Cross-over with } 3 \text { or } 4 \text { days Interval } \\
\text { No prior loadıng } \\
\text { Treatment oral dose of } 300 \mathrm{~mL} \text { water with either } 06 \\
\left.\mu m o l \text { [ }{ }^{3} \mathrm{H}\right] \text { PteGlu, or } 06 \mu \mathrm{mol}\left[{ }^{3} \mathrm{H}\right] \text { PteGlu, After } 4 \text { hours } \\
\text { a flushing dose of } 15 \mathrm{mg} \text { unlabelled folıc acid was } \\
\text { given } \\
\text { Chain length PteGlu, versus PteGlu, } \\
\text { Measurement urınary excretion of folate over } 48 \text { hours }\end{array}$ & $\begin{array}{l}\text { Folate urınary excretion } \\
\text { PteGlu, } 708 \pm 130 \text { (mean } \pm \text { SD) } \\
\text { PteGlu, } 561 \pm 112\end{array}$ & $\begin{array}{l}\text { This study shows that physiological } \\
\text { doses of both monoglutamyl and } \\
\text { heptaglutamyl folıc acid are } \\
\text { absorbed PteGlu, seems to be } \\
\text { slightly better absorbed than } \\
\text { PteGlu, }\end{array}$ \\
\hline $\begin{array}{l}\text { Halsted, } \\
\text { Baugh \& } \\
\text { Butterworth, } \\
1975\end{array}$ & $\begin{array}{l}\text { Subjects } 5 \text { healthy volunteers } \\
\text { Design Jejunal perfusion of }\left[{ }^{3} \mathrm{H}\right] \mathrm{PteG} \mathrm{u}_{1} \text { and } \\
{\left[{ }^{14} \mathrm{C}\right] \mathrm{PteGlu}} \\
\text { No prior loading } \\
\text { Treatment Equimolar solutions of }[\mathrm{H} \mathrm{H}] \mathrm{PteGlu}, \text { and } \\
{\left[{ }^{14} \mathrm{C}\right] \mathrm{PteGlu}, \text { were provided }} \\
\text { Chain length PteGlu, versus PteGlu, } \\
\text { Measurement luminal disappearance }\end{array}$ & $\begin{array}{l}\text { Percentage lumınal } \\
\text { disappearance } \\
\text { PteGlu, } 747 \% \\
\text { PteGlu, } 526 \%\end{array}$ & $\begin{array}{l}\text { PteGlu, and PteGlu, are both taken } \\
\text { up by the jejunum The uptake of } \\
\text { PteGlu, seems higher than the } \\
\text { uptake of PteGlu, }\end{array}$ \\
\hline
\end{tabular}




\begin{tabular}{|c|c|c|c|}
\hline Authors & Design & Results & Conclusions and comments \\
\hline $\begin{array}{l}\text { Halsted et al } \\
1978\end{array}$ & 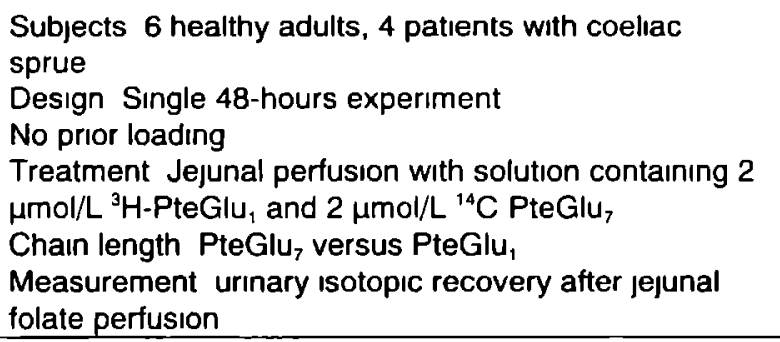 & $\begin{array}{l}\text { The urinary recovery of PteGlu7 } \\
\text { was lower than that of PteGlu, }\end{array}$ & $\begin{array}{l}\text { The bioavallability of the } \\
\text { monoglutamate seems to be } \\
\text { greater than the bioavallability of } \\
\text { the polyglutamate }\end{array}$ \\
\hline $\begin{array}{l}\text { Balley et al } \\
1984\end{array}$ & 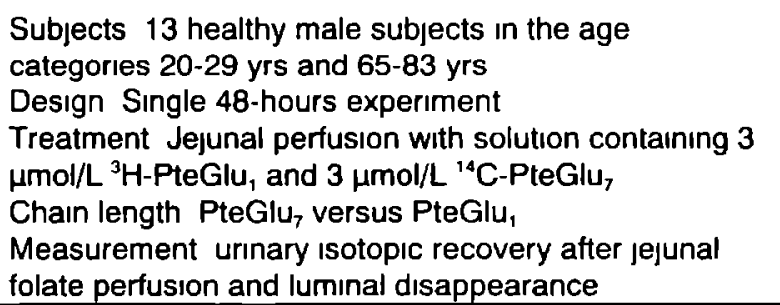 & $\begin{array}{l}\text { Both urınary recovery and lumınal } \\
\text { disappearance were higher for } \\
\text { PteGlu, than for PteGlu, in } \\
\text { subjects of both age categories }\end{array}$ & $\begin{array}{l}\text { This study suggests higher } \\
\text { bıoavallability of folic acid than of } \\
\text { pteroylheptaglutamate }\end{array}$ \\
\hline $\begin{array}{l}\text { Bailey et al , } \\
1988\end{array}$ & $\begin{array}{l}\text { Subjects } 9 \text { healthy males (fasting) } \\
\text { Design Cross-over with two weeks interval } \\
\text { No prior loading } \\
\text { Treatment Single dose of } 750 \mu g \text { PteGlu, or equivalent } \\
\text { amount of PteGlu }{ }_{7} \text { given in solution or with bran or } \\
\text { spinach } \\
\text { Chain length PteGlu versus PteGlu, } \\
\text { Measurement Area under the curve (AUC) of serum } \\
\text { folate for } 8 \text { hours }\end{array}$ & $\begin{array}{l}\text { AUC's of PteGlu, and PteGlu } \\
\text { were not different when ingested } \\
\text { as solution or with spinach AUC } \\
\text { for PteGlu, ingested with bran was } \\
\text { lower than PteGlu, ingested with } \\
\text { bran }\end{array}$ & $\begin{array}{l}\text { This study suggests no effect of } \\
\text { chain length when ingested as } \\
\text { solution, but an inhibiting effect of } \\
\text { dietary fibre on bioavailability of } \\
\text { PteGlu, compared to PteGlu, }\end{array}$ \\
\hline
\end{tabular}




\begin{tabular}{|c|c|c|c|}
\hline Authors & Design & Results & Conclusions and comments \\
\hline $\begin{array}{l}\text { Keagy, Shane } \\
\& \text { Oace, } 1988\end{array}$ & $\begin{array}{l}\text { Subjects } 7 \text { healthy young men } \\
\text { Design All subjects received all treatments } \\
\text { Constant loading with } 500 \mu \mathrm{g} \text { of folic acid per day } \\
\text { Treatment Folate absorption tests were conducted } \\
\text { during the last four days of a } 9 \text { d period in which } \\
\text { subjects received PteGlu, and PteGlu7 in a formula on } \\
\text { alternate days } \\
\text { Chain length PteGlu, and PteGlu7 } \\
\text { Measurement Serum folate after } 1 \text { and } 2 \text { hours and } \\
\text { urine excretion ( } 24 \mathrm{hrs} \text { ) }\end{array}$ & $\begin{array}{l}\text { PteGlu, produced a lower rise in } \\
\text { serum folate and in urinary } \\
\text { excrelion PteGlu, excretion was } \\
63 \% \text { of PteGlu, excretion }\end{array}$ & $\begin{array}{l}\text { This study suggests that } \\
\text { bioavallability of PteGlu, is either } \\
\text { lower or takes longer than } \\
\text { bioavallability of PteGlu, }\end{array}$ \\
\hline $\begin{array}{l}\text { Gregory et al } \\
1991\end{array}$ & $\begin{array}{l}\text { Subjects } 7 \text { adult males (fastıng) } \\
\text { Desıgn Withın person comparıson ( } 3 \text { weeks Interval) } \\
\text { Prior loadıng } 2 \mathrm{mg} \text { PteGlu for } 7 \text { days } \\
\text { Treatment Oral dose of } 677 \text { nmol d2-folate followed by } \\
\text { intravenous dose of } 502 \text { nmol d4-PteGlu, } \\
\text { Chain length PteGiu }{ }_{6} \text { versus PteGlu, } \\
\text { Urıne was collected for } 48 \text { hours } \\
\text { Measurement Excretıon ratıo of urinary folates (\% d2- } \\
\text { folate dose/ \% d4-PteGlu dose) }\end{array}$ & $\begin{array}{l}\text { Urınary excretıon ratıos } \\
\text { PteGlu, } 145 \pm 010 \text { (mean } \pm \\
\text { SEM) } \\
\text { PteGlu }_{6} 067 \pm 004\end{array}$ & $\begin{array}{l}\text { This study suggests that PteGlu } \\
\text { less bioavarlable than PteGlu, }\end{array}$ \\
\hline $\begin{array}{l}\text { Wel et al } \\
1996\end{array}$ & 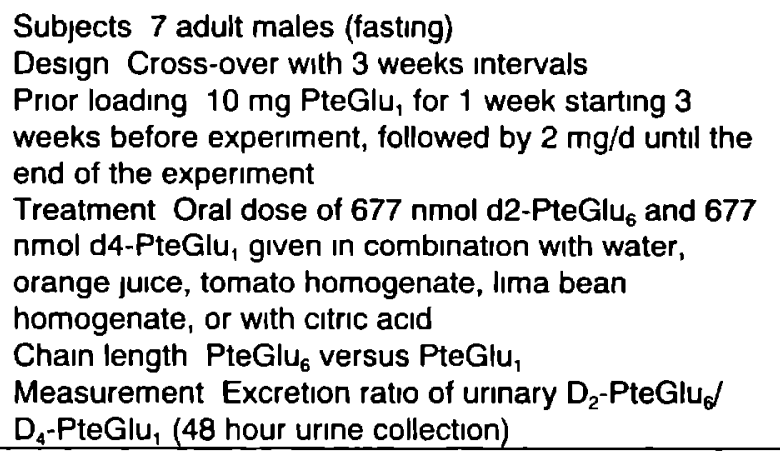 & $\begin{array}{l}\text { The } D_{2} / D_{4} \text { excretion ratio for } \\
\text { tomato, lima beans and citrate } \\
\text { butfer was similar to the ratio of } \\
\text { the control }(100 \pm 017 \text {, mean } \pm \\
S D) \text { The } D_{2} / D_{4} \text { ratio for orange } \\
\text { juice was significantly lower } \\
(\sim 66 \% \text { relative to that in the } \\
\text { control trials) }\end{array}$ & $\begin{array}{l}\text { These findings indicate that orange } \\
\text { juice affects the absorption of orally } \\
\text { taken polyglutamate This would } \\
\text { imply that the effect occurs at the } \\
\text { level of the intestinal deconjugation } \\
\text { process by pteroylpolyglutamate } \\
\text { hydrolyse }\end{array}$ \\
\hline
\end{tabular}




\section{Amount of folate / folic acid}

Bioavailability of folate or folic acid is likely to be influenced by the amount ingested. For absorption, there are two different transport systems. In the first transport system, folates are bound to membrane-associated folate-binding proteins and transported across the brush border membrane by a carrier-mediated mechanism. However, at high intraluminal concentration of folate $(>10 \mu \mathrm{mol} / \mathrm{L})$ a second nonsaturable diffusion-mediated transport system plays a major role in folate absorption (Mason, 1990). The amount ingested is most likely to be of significance if the saturable transport system is saturated. At physiological concentrations $\quad<5$ $\mu \mathrm{mol} / \mathrm{L})$ of folate in the lumen transport occurs mainly via the saturable transport system (Mason, 1990). The amount of natural food folate normally ingested is not likely to reach an intake level that causes saturation of this transport system. However, with intake of synthetic folic acid this level can easily be reached.

Many studies investigated effects of amount of synthetic folic acid (PteGlu $)$ on bioavailability (Table 7.3). Heseker \& Schmitt showed that plasma folate reached a steady state after four weeks of supplementation with $1 \mathrm{mg}$ of folic acid daily. Levels in red blood cells increased over the total intervention period of 17 weeks (Heseker and Schmitt, 1987). This synchronises with the lifetime of the red blood cell, which is known to incorporate folate only during erythropoiesis (Shane, 1995). Truswell and Kounnavong (1997) gave in several experiments folic acid supplements, containing either $100 \mu \mathrm{g}$, or $500 \mu \mathrm{g}$, or $1000 \mu \mathrm{g}$ of folic acid per day, for 3 weeks in addition to the regular diet. The relative biggest increase in plasma folate was established by the $100 \mu \mathrm{g}$ of folic acid, but the absolute biggest increase was established by intake of the highest dose of folic acid. The study does not make clear whether on the long term the same level of serum folate can be reached (Truswell and Kounnavong, 1997). Malinow et al. (1998) also showed in a cross-over study that a dose of $127 \mu \mathrm{g}$ of folic acid daily for 5 weeks was relatively more effective in raising plasma folate $(30.8 \%)$ than doses of $499 \mu \mathrm{g}(64.8 \%)$ and $665 \mu \mathrm{g}$ $(105.7 \%)$ daily. This suggests that lower doses of folic acid increase plasma folate concentrations most effectively (Malinow et al., 1998). However, the plasma folate raising effect might be slightly underestimated in the groups receiving the higher doses because the washout period between the intervention periods was only five weeks (Malinow et al., 1998). This period is probably too short to avoid a carry-over effect (Brouwer et al., 1999). 
Plasma total homocysteine concentration is a functional parameter of folate status. Therefore, the effect of folic acid on plasma total homocysteine concentrations can be described as bioefficacy. Many authors have investigated the effects of different amounts of folic acid on plasma total homocysteine concentrations. Clarke compared in a meta-analysis (Homocysteine Lowering Trialists' Collaboration, 1998) most of these studies. This meta-analysis showed similar homocysteine-lowering effects for doses between 0.5 and $5 \mathrm{mg}$ of folic acid. Thus, it seemed as if doses above $500 \mu \mathrm{g}$ of folic acid had no additional homocysteine-lowering effect. Besides the articles mentioned in the meta-analysis, a few other authors studied effects of lower doses of folic acid on plasma total homocysteine concentrations. Ward et al. (1997) showed that $200 \mathrm{\mu g}$ of folic acid had a similar effect as $400 \mu \mathrm{g}$ of folic acid per day. However, six weeks of supplementation with $100 \mu \mathrm{g}$ of folic acid was not sufficient to reach a similar level of plasma total homocysteine. The latter study does not exclude the possibility that giving the $100 \mu \mathrm{g}$ of folic acid for a longer period would have resulted in lower plasma total homocysteine concentrations. Malinow et al. (1998) found in their study no significant decrease in plasma total homocysteine concentrations after five weeks of supplementation with $127 \mu \mathrm{g}$ of folic acid per day. However, the design of the study makes it difficult to interpret their results.

\section{Non-metabolised folic acid}

Kelly et al. (1997) found unmetabolised fully oxidised folic acid (PteGlu $)_{1}$ in serum of subjects receiving more than $266 \mu \mathrm{g}$ of folic acid per day. They suggest that the excess of folic acid might not bè available for lowering plasma total homocysteine. This is in line with other studies that show no additional homocysteine lowering effect of doses of folic acid above $500 \mu \mathrm{g}$, or even $200 \mu \mathrm{g}$ of folic acid (Bonnette et al., 1998; Homocysteine Lowering Trialists' Collaboration, 1998; Schorah et al., 1998; Ward et al., 1997). 
Table 7.3 Effect of Amount of folic acid consumed on folic acid bioavailability (human intervention studies)

\begin{tabular}{|c|c|c|c|}
\hline Authors & Design & Results & Conclusions and comments \\
\hline $\begin{array}{l}\text { Heseker \& } \\
\text { Smith, } 1987\end{array}$ & $\begin{array}{l}\text { Subjects: } 6 \text { healthy subjects ( } 4 \text { men, } 2 \text { women). } \\
\text { Design: parallel. } \\
\text { No prior loading. } \\
\text { Treatment: } 500 \mu \mathrm{g} \text { folic acid was administered } 2 \text { times } \\
\text { daily for } 17 \text { weeks in addition to their regular diet. } \\
\text { Measurement: Plasma and red blood cell folate. }\end{array}$ & $\begin{array}{l}\text { The mean folate concentration in } \\
\text { plasma reached a steady state } \\
\text { after } \pm 4 \text { weeks. This level was } \\
\text { maintained by continuous doses } \\
\text { of folic acid. } \\
\text { Levels in red blood cell } \\
\text { increased continuously during } 17 \\
\text { weeks. }\end{array}$ & $\begin{array}{l}\text { A daily dose of } 1 \mathrm{mg} \text { was } \\
\text { sufficient to reach a steady state } \\
\text { for plasma folate after four } \\
\text { weeks. } \\
\text { Red blood cells only incorporate } \\
\text { folate during erythropoiesis. Life } \\
\text { time of the red blood cell is } \\
\text { approximately } 120 \text { days. } \\
\text { Therefore, it will take around } 120 \\
\text { days to reach steady state in red } \\
\text { blood cells. }\end{array}$ \\
\hline $\begin{array}{l}\text { Ward et al. } \\
1997\end{array}$ & $\begin{array}{l}\text { Subjects: } 30 \text { healthy males. } \\
\text { Design: Sequential design. } \\
\text { No prior loading. } \\
\text { Treatment: folic acid was administered daily at doses } \\
\text { increasing from } 100 \mu g \text { ( } 6 \text { weeks), to } 200 \mu g \text { ( } 6 \text { weeks), to } \\
400 \mu g \text { ( } 14 \text { weeks) in addition to the regular diet. } \\
\text { Measurement: Fasting total plasma homocysteine, serum } \\
\text { folate and red blood cell folate (measured at start and end } \\
\text { of study). }\end{array}$ & $\begin{array}{l}\text { - Both } 100 \text { and } 200 \mu \mathrm{g} \text { of folic } \\
\text { acid significantly decreased total } \\
\text { plasma homocysteine, } 400 \mu \mathrm{g} \\
\text { had no further decreasing effect. } \\
\text { - Serum folate increased } \\
\text { gradually with all three doses. } \\
\text { - Red blood cell folate increased } \\
\text { over the study period. }\end{array}$ & $\begin{array}{l}\text { A dose of } 200 \mu \mathrm{g} \text { of folic acid } \\
\text { daily seems as effective as } 400 \\
\mu \mathrm{g} \text { daily in lowering total plasma } \\
\text { homocysteine. It is not clear } \\
\text { whether } 100 \mu \mathrm{g} \text { daily in the long } \\
\text { term could be as effective as } \\
200 \mu \mathrm{g} \text {. }\end{array}$ \\
\hline
\end{tabular}




\begin{tabular}{|c|c|c|c|}
\hline Authors & Desıgn & Results & Conclusions and comments \\
\hline $\begin{array}{l}\text { Truswell \& } \\
\text { Kounnavong, } \\
1997\end{array}$ & $\begin{array}{l}\text { Subjects exp } 1 n=13, \exp 2 n=16, \exp 3 n=6 \text { ( } n=6 \\
\text { completed all } 3 \text { experiments) } \\
\text { Desıgn Parallel, consecutive exp ( } 28 \text { days between exp) } \\
\text { No prior loadıng } \\
\text { Treatment Subjects received folıc acid supplements (In } \\
\text { aqueous solution) in additıon to theır regular diet } \\
\text { Exp } 1100 \mu g \text { for } 3 \text { weeks, then } 1000 \mu g \text { for } 3 \text { weeks } \\
\text { Exp } 2500 \mu g \text { for } 3 \text { weeks, then } 1500 \mu g \text { for } 3 \text { weeks } \\
\text { Exp } 31000 \mu g \text { for } 3 \text { weeks, then } 2000 \mu g \text { for } 3 \text { weeks } \\
\text { Measurement response in serum folate after } 2 \text { and } 3 \\
\text { weeks }\end{array}$ & $\begin{array}{l}\text { The relative biggest increase } \\
\text { was for the first } 100 \mu \mathrm{g} \text { of folic } \\
\text { acıd } \\
\text { Serum folates appeared to take } \\
\text { longer to reach the highest } \\
\text { possıble level after small doses } \\
\text { of folıc acıd than after doses of } \\
1000 \mu \mathrm{g} / \mathrm{d} \text { or more }\end{array}$ & $\begin{array}{l}\text { The wash out period between } \\
\text { the experıments was only four } \\
\text { weeks Therefore the startıng } \\
\text { value of serum folate increased } \\
\text { from experıment } 1 \text { to } 3\end{array}$ \\
\hline $\begin{array}{l}\text { Kelly et al } \\
1997\end{array}$ & 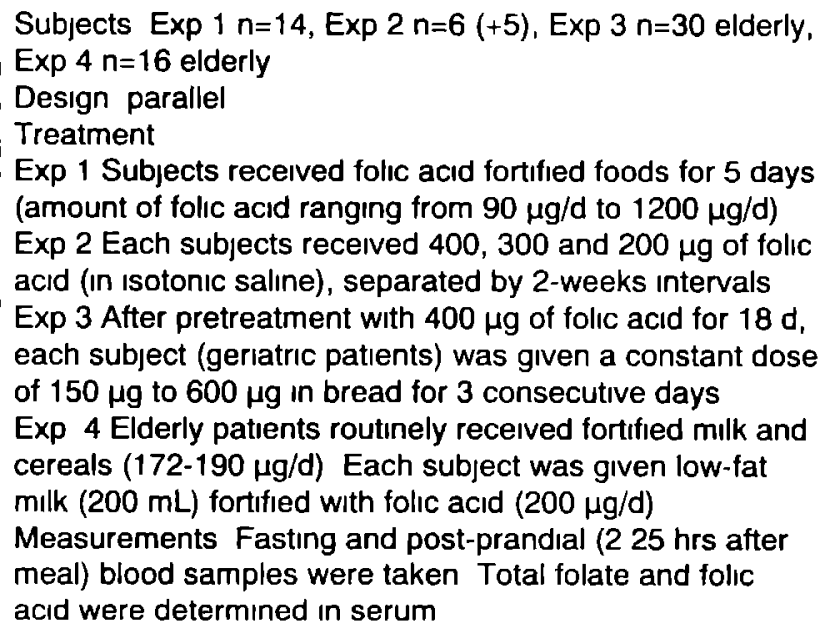 & $\begin{array}{l}\text { Unaltered folıc acid was found in } \\
\text { subjects consumıng more than } \\
266 \mu g \text { of folıc acid per day }\end{array}$ & $\begin{array}{l}\text { It is not clear what the } \\
\text { implications are of having free } \\
\text { folic acid in the serum }\end{array}$ \\
\hline
\end{tabular}




\begin{tabular}{|c|c|c|c|}
\hline Authors & Design & Results & Conclusions and comments \\
\hline $\begin{array}{l}\text { Caudill et al } \\
1997+1998\end{array}$ & $\begin{array}{l}\text { Subjects } 12 \text { pregnant and } 12 \text { nonpregnant women } \\
\text { No prior loading } \\
\text { Design parallel } \\
\text { Treatment Women received daily } 120 \mu \mathrm{g} \text { folate/day and } \\
\text { either } 330 \mu \mathrm{g} \text { or } 730 \mu \mathrm{g} \text { folic acıd/day for } 12 \text { weeks } \\
\text { Measurement (1997) Serum folate, red blood cell folate } \\
\text { and urınary 5-methyl-PteGlu excretion } \\
\text { Measurement (1998) Excretion of folate catabolites, para- } \\
\text { amınobenzoylglutamate (pABG) and } \\
\text { acetamıdobenzoylglutamate (apABG) }\end{array}$ & $\begin{array}{l}\text { Less excretion of folate } \\
\text { catabolites in the group receiving } \\
450 \mu \mathrm{g} \text { of folate than in the } \\
\text { group receiving } 850 \mu \mathrm{g} \text { of folate }\end{array}$ & $\begin{array}{l}\text { The amount of folate of } 450 \mu \mathrm{g} \\
\text { seems to be used more } \\
\text { efficiently than the amount of } \\
850 \mu \mathrm{g}\end{array}$ \\
\hline $\begin{array}{l}\text { Homocysteine } \\
\text { Lowerıng } \\
\text { Trialısts' } \\
\text { Collaboration, } \\
1998\end{array}$ & $\begin{array}{l}\text { Meta-analysis of randomısed trials } \\
\text { Subjects Individual data on } 1114 \text { people included in } 12 \\
\text { trials } \\
\text { Design meta-analysis of effects of folic acid based } \\
\text { supplements on total plasma homocysteıne } \\
\text { concentrations Folic acid was provided in various doses } \\
(04 \text { to } 5 \mathrm{mg}) \text { in addition to the diet } \\
\text { Measurement Total plasma homocysteine }\end{array}$ & $\begin{array}{l}\text { There was no evidence for } \\
\text { differences in homocysteıne } \\
\text { lowering effects between dally } \\
\text { doses of }<1 \mathrm{mg} \text { (mean dose } 05 \\
\mathrm{mg} \text { ), of } 1-3 \mathrm{mg} \text {, or of }>3 \mathrm{mg} \text { folic } \\
\text { acid }\end{array}$ & $\begin{array}{l}\text { Doses of } 05 \mathrm{mg} \text { of folic acid } \\
\text { seemed as effective in lowering } \\
\text { total plasma homocysteine as } \\
\text { doses above that level There } \\
\text { were no studies in the meta- } \\
\text { analysis investıgating doses } \\
\text { lower than } 04 \mathrm{mg} \text { folic acid }\end{array}$ \\
\hline $\begin{array}{l}\text { Malınow et al } \\
1998\end{array}$ & $\begin{array}{l}\text { Subjects } 75 \text { subjects with coronary artery disease ( } n=25 \\
\text { per treatment) } \\
\text { No prior loading } \\
\text { Design Cross-over between treatment and placebo } \\
\text { Tretament Subjects received } 30 \mathrm{~g} \text { cereal supplemented } \\
\text { with either } 127 \mu \mathrm{g} \text { of folıc acid, } 499 \mu \mathrm{g} \text { of folic acid or } 665 \\
\mu \mathrm{g} \text { of folic acid for five weeks Wash-out period was five } \\
\text { weeks } \\
\text { Measurement Total plasma homocysteine and plasma } \\
\text { folate }\end{array}$ & $\begin{array}{l}\text { All doses significantly increased } \\
\text { plasma folate levels A dose of } \\
499 \mu \mathrm{g} \text { and } 665 \mu \mathrm{g} \text { of folıc acıd } \\
\text { decreased total plasma } \\
\text { homocysteıne significantly by } \\
\text { respectively } 11 \text { and } 14 \text { percent } \\
\text { A dose of } 127 \mu \mathrm{g} \text { of folic acid } \\
\text { resulted in a non-significant } \\
\text { decrease of } 37 \text { percent }\end{array}$ & $\begin{array}{l}\text { A wash-out period of } 5 \text { weeks is } \\
\text { too short for total plasma } \\
\text { homocysteine concentrations to } \\
\text { return to baselıne } \\
\text { It is not clear whether subjects } \\
\text { were already taking folıc acıd } \\
\text { fortified foods before the trial } \\
\text { started and even durıng the trial }\end{array}$ \\
\hline
\end{tabular}




\begin{tabular}{|c|c|c|c|}
\hline Authors & Design & Results & Conclusions and comments \\
\hline $\begin{array}{l}\text { Schorah et al } \\
1998\end{array}$ & $\begin{array}{l}\text { Subjects } 94 \text { healthy volunteers } \\
\text { No prior loadıng } \\
\text { Desıgn Parallel } \\
\text { Treatment Subjects received either unfortified cereals, or } \\
\text { cereals fortified with } 200 \mu g \text { of folıc acıd, or cereals } \\
\text { fortifıed with } 200 \mu \mathrm{g} \text { of folıc acid and other vitamıns } \\
\text { Measurement Total homocysteıne, cysteine and vitamın } \\
\text { B12 in plasma, serum folate and red blood cell folate at } \\
\text { weeks } 0,4,8 \text { and } 24\end{array}$ & $\begin{array}{l}\text { Folic acid supplementation } \\
\text { significantly increased serum } \\
\text { folate }(66 \%) \text { and red blood cell } \\
\text { folate }(24 \%) \text { and decreased } \\
\text { homocysteine }(10 \%) \text { There was } \\
\text { no additional effect of the other } \\
\text { vitamins in the fortified cereals. }\end{array}$ & $\begin{array}{l}\text { A dose of } 200 \mu g \text { of folic acid in } \\
\text { addition to the regular diet was } \\
\text { sufficient to significantly } \\
\text { decrease total plasma } \\
\text { homocysteine concentrations } \\
\text { and increase serum and red cell } \\
\text { tolate }\end{array}$ \\
\hline $\begin{array}{l}\text { Bonnette et al } \\
1998\end{array}$ & $\begin{array}{l}\text { Dietary controlled trial } \\
\text { Subjects } 12 \text { pregnant women (weeks } 14 \text { to } 26 \text { ) and } 12 \\
\text { nonpregnant women } \\
\text { Design Two-by-two factorial } \\
\text { No prior loadıng } \\
\text { Treatment All subjects received dally } 120 \mu \mathrm{g} \text { food folate } \\
\text { and either } 330 \mu \mathrm{g} \text { or } 730 \mu \mathrm{g} \text { supplemental folıc acıd for } 12 \\
\text { weeks } \\
\text { Measurements Total plasma homocysteıne weekly }\end{array}$ & $\begin{array}{l}\text { Total plasma homocysteine } \\
\text { concentrations in pregnant and } \\
\text { nonpregnant women remain } \\
\text { constant with both doses withın } \\
\text { four weeks } \\
\text { No significant difference } \\
\text { between the doses was shown }\end{array}$ & $\begin{array}{l}\text { No significant differences } \\
\text { between the doses were shown } \\
\text { However, the power of the study } \\
\text { was such that only differences } \\
\text { among the groups of more than } \\
3 \mu \mathrm{mol} \text { thcy could be detected }\end{array}$ \\
\hline
\end{tabular}




\section{Matrix}

Matrix effects on bioavailability involve effects of encapsulation and binding. Natural food folate can be encapsulated in plant cells or subcellular components. Generally for folic acid added to food binding would be the main problem although in the preparation encapsulation may occur.

Comparison of folate bioavailability among different foods involves besides matrix effects of molecular linkage, species and effect modifiers. However, studies comparing folate bioavailability among foods cannot distinguish between these factors. Matrix is probably the main factor, therefore we have decided to discuss human studies in which folate bioavailability of different foods is compared in this section (Table 7.4).

Retief was one of the first researchers to study effects of different foods on folate bioavailability (Retief, 1969). However, this study is not included in Table 7.4 because he studied only one subject. Studies investigating the effect of food matrix of single foods on the bioavailability of dietary folate showed that folate was absorbed to some extent (Babu and Srikantia, 1976; Keagy et al., 1988; Retiet, 1969; Sauberlich et al., 1987; Tamura and Stokstad, 1973; Chapter 6). However, the bioavailability of food folate relative to folic acid differed enormously between products (Babu and Srikantia, 1976; Keagy et al., 1988; Retief, 1969; Sauberlich et al., 1987; Tamura and Stokstad, 1973).

Few studies investigated bioavailability of folate from mixed diets. Sauberlich et al. (1987) estimated from a strictly controlled trial that the bioavailability of a mixed diet would be no higher than $50 \%$. Our group (Chapter 6 ) found a bioavailability of folate from vegetables and citrus fruit of 60 to $98 \%$ relative to folic acid, depending on the endpoint chosen. The fact that the folic acid tablets were taken every other day may have overestimated the effect of food folate slightly (Chapter 4). Cuskelly et al. (1996) provided dietary folate to women in the free-living situation and found no significant improvement in red blood cell folate concentrations. The small number of participants per group in that study might have affected the results (Cuskelly et al., 1996). Thus, folate from a mixed diet might be absorbed for more than $50 \%$. However, it is difficult to predict how much folate from a mixed diet is absorbed because folate occurs in many different food products. Bioavailability of a mixed diet might also be expected to depend on other factors besides the matrix.

The US Federal Government has introduced mandating fortification with folic acid of flour products as from January 1,1998 . This was accomplished to increase 
the folic acid intake of women in the fertile age group because a higher intake lowers the risk of having offspring with a neural-tube defect (US Department of Health and Human Services. Food and Drug Administration, 1996). Therefore, it is important to know the effect of flour and of other food which may be eaten at the same time and to know the bioavailability of folic acid added as fortificant.

Several studies from a research group in Johannesburg (Colman, 1982; Colman et al., 1975; Margo et al., 1975) investigated the effects of maize meal, rice and bread on the bioavailability of folic acid (Table 7.4). They found that the bioavailability of folic acid consumed with bread was $58 \%$ (range, $42-84 \%$ ) of that when it was consumed with water (Colman et al., 1975). In contrast, wheat bran was found to stimulate rather than inhibit the serum folate response to feeding folic acid (Keagy et al., 1988). The enhancing effect of bran might be due to endogenous folate in wheat bran, but interaction of bran with folate inhibitors cannot be excluded. Bailey et al. (1988) also showed no inhibiting effect of bran on the absorption of folic acid, although bran decreased the absorption of PteGlu7. Pfeiffer et al. (1997) used a dual-label stable isotope protocol to determine absorption of folic acid fortified cereal-grain products. No significant differences were shown between white bread, whole wheat bread, rice, pasta or solution. The fact that the between subject variation was high in this study might have considerably affected the results (Pfeiffer et al., 1997). 
Table 7.4 Effect of food Matrix of single foods and mixed diets on bioavailability of folate and folic acid

\begin{tabular}{|c|c|c|c|}
\hline & Design & Results & Conclusions and comments \\
\hline $\begin{array}{l}\text { Tamura \& } \\
\text { Stokstad, } \\
1973\end{array}$ & $\begin{array}{l}\text { Human intervention study } \\
\text { Subjects } n=6 \text { healthy males } \\
\text { Design Cross-over } \\
\text { Prior loadıng with folıc acid } 2 \times 10 \mathrm{mg} \text { on first day, } 5 \\
\text { mg on second day, } 2 \text { mg on third day Then } 2 \mathrm{mg} \\
\text { every other day } \\
\text { Treatment Each subject receıved different foods } \\
\text { orange juice, romaine lettuce, romaine lettuce } \\
\text { extract, egg yolk, banana, lıma beans (dry and } \\
\text { frozen), liver, brewer's yeast, brewer's yeast extract, } \\
\text { cabbage (cooked and raw), defatted soybean meal, } \\
\text { wheat germ } \\
\text { Measurement Urinary folate excretion ( } 24 \text { hours) }\end{array}$ & $\begin{array}{l}\text { Bioavaılability of food relative to folıc acıd } \\
\text { Orange juice } 31 \%(1740) \\
\text { Romaine lettuce } 25 \%(12-37) \\
\text { Romaine extract } 48 \%(38-52) \\
\text { Egg yolk } 59 \%(23-129) \\
\text { Banana } 82 \%(0-148) \\
\text { Lima beans (dry, cooked) } 70 \%(0-138) \\
\text { Lima beans (frozen, cooked) } 96 \%(48-181) \\
\text { Liver (cooked) } 50 \%(22-103) \\
\text { Brewer's yeast } 60 \%(55-67) \\
\text { Brewer's yeast extract } 63 \%(59-69) \\
\text { Cabbage (cooked) } 47 \%(0-127) \\
\text { Cabbage (raw) } 47 \%(093) \\
\text { Defatted soybean meal } 46 \%(6-83) \\
\text { Wheat germ } 30 \%(0-64)\end{array}$ & $\begin{array}{l}\text { The large amounts of food, } \\
\text { e g } 500700 \mathrm{~g} \text { of cabbage } \\
\text { and lettuce may have } \\
\text { adversely affected the } \\
\text { bioavarlability } \\
\text { The bioavallability of folate } \\
\text { varies considerably between } \\
\text { products For all products is } \\
\text { the mean relative } \\
\text { bioavallability lower than for } \\
\text { folic acid }\end{array}$ \\
\hline
\end{tabular}




\begin{tabular}{|c|c|c|c|}
\hline & Design & Results & Conclusions and comments \\
\hline $\begin{array}{l}\text { Colman et al } \\
1975\end{array}$ & 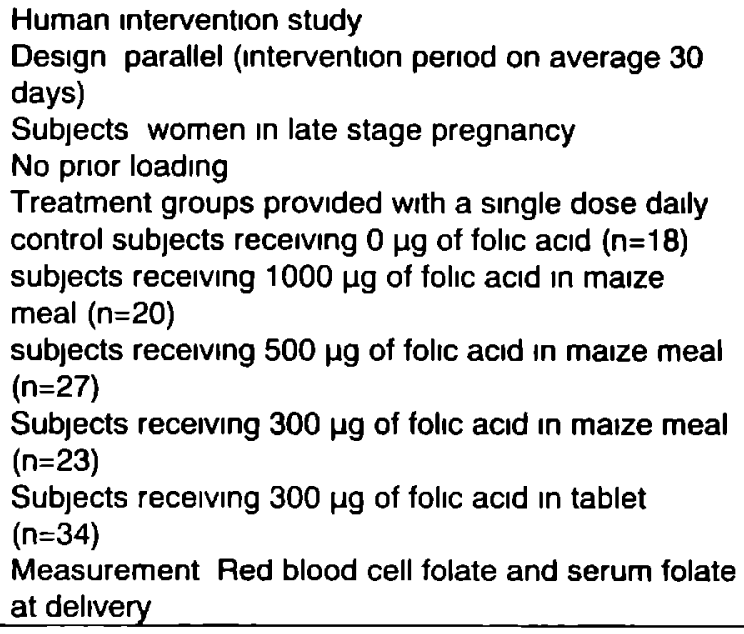 & $\begin{array}{l}\text { Red blood cell folate } \\
\text { The slope of the group receiving } 500 \mu \mathrm{g} \text { of } \\
\text { folic acid in maize meal was similar to that } \\
\text { of the group receiving } 300 \mu \mathrm{g} \text { of folıc acıd } \\
\text { in a tablet } \\
\text { Serum folate } \\
\text { The slope of the regression lines in all four } \\
\text { intervention groups was significantly } \\
\text { greater than in the control group The } \\
\text { slopes seemed similar for } 300 \mu \mathrm{g} \text { of folıc } \\
\text { acid in maize, } 300 \mu \mathrm{g} \text { of folic acid in tablet } \\
\text { and for } 500 \mu \mathrm{g} \text { of folıc acid in maize }\end{array}$ & $\begin{array}{l}\text { This study suggests that } 500 \\
\mu g \text { of folic acid in maize meal } \\
\text { was equally efficient as } 300 \\
\mu g \text { of folic acid in a tablet }\end{array}$ \\
\hline $\begin{array}{l}\text { Colman, } \\
\text { Green \& } \\
\text { Metz, } 1975\end{array}$ & $\begin{array}{l}\text { Human intervention study } \\
\text { Subjects } n=7 \text { healthy adults } \\
\text { Design Cross-over } \\
\text { Prior loading with } 15 \mathrm{mg} \text { of folıc acid dally for } 3 \text { days } \\
\text { Treatment Subjects received } 1 \mathrm{mg} \text { of folic acid in } \\
\text { elther an aqueous solution, or in maize, in bread, or } \\
\text { rice for } 4 \text { consecutive days } \\
\text { Measurement Sum of rise in serum folate } 1 \text { and } 2 \\
\text { hours after ingesting the folic acid on day } 4\end{array}$ & $\begin{array}{l}\text { Relative bioavailability of fortified products } \\
\text { compared to folic acid in aqueous solution } \\
\text { Maize } 53 \% \text { (range } 32-77 \% \text { ) } \\
\text { Rice } 58 \%(42-84 \%) \\
\text { Bread } 38 \%(18-68 \%)\end{array}$ & $\begin{array}{l}\text { This study suggests that folic } \\
\text { acid provided in combination } \\
\text { with maize, rice or bread } \\
\text { takes either a longer time to } \\
\text { be absorbed or is less } \\
\text { bioavailable than folic acid in } \\
\text { a solution } \\
\text { The folıc acid is supplied to } \\
\text { the products before } \\
\text { preparation Preparation } \\
\text { might have destroyed some } \\
\text { of the folıc acid }\end{array}$ \\
\hline
\end{tabular}




\begin{tabular}{|c|c|c|c|c|}
\hline & Design & \multicolumn{2}{|l|}{ Results } & Conclusions and comments \\
\hline $\begin{array}{l}\text { Margo et al. } \\
1975\end{array}$ & $\begin{array}{l}\text { Human intervention study. } \\
\text { Design. One group compared with Colman et al } \\
1975 . \\
\text { Subjects women in late stage pregnancy }(n=15) \text {. } \\
\text { No prior loading } \\
\text { Treatment. Subjects received dally } 900 \mu \mathrm{g} \text { of folic } \\
\text { acid in bread } \\
\text { Measurement Red cell folate concentratıons. }\end{array}$ & \multicolumn{2}{|c|}{$\begin{array}{l}\text { The increase in red blood cell folate } \\
\text { concentrations was sımılar to the increase } \\
\text { observed in the groups receiving } 300 \mu \mathrm{g} \text { of } \\
\text { folıc acıd in a tablet or } 500 \mu \mathrm{g} \text { of folıc acid } \\
\text { in maize meal (Colman et al. 1975). }\end{array}$} & $\begin{array}{l}\text { It is not clear whether the } \\
\text { amount of folic acid in the } \\
\text { bread was measured before } \\
\text { of after processing of the } \\
\text { bread. }\end{array}$ \\
\hline $\begin{array}{l}\text { Babu \& } \\
\text { Srıkantıa, } \\
1976\end{array}$ & $\begin{array}{l}\text { Human intervention study. } \\
\text { Subjects. } n=10 \text { healthy males. } \\
\text { Design. cross-over } \\
\text { Prior loading with } 5 \mathrm{mg} \text { for } 6 \text { days, followed by } 2 \mathrm{mg} \\
\text { every other day }+400 \mu \mathrm{g} \text { of folic acid was provided } \\
\text { with each food. } \\
\text { Treatment A single meal of the following foods was } \\
\text { provided. } \\
\text { Bengal gram ( } 282 \mu \mathrm{g} \text { of folate). } \\
\text { Green gram ( } 314 \mu \mathrm{g} \text { of folate). } \\
\text { Tomato ( } 300 \mu \mathrm{g} \text { of folate). } \\
\text { Spınach ( } 310 \mu \mathrm{g} \text { of folate). } \\
\text { Banana ( } 192-252 \mu \mathrm{g} \text { of folate). } \\
\text { Egg ( } 210-350 \mu \mathrm{g} \text { of folate) } \\
\text { Goat liver ( } 315 \mu \mathrm{g} \text { of folate). } \\
\text { Brewer's yeast }(300 \mu \mathrm{g} \text { of folate). } \\
\text { Measurement: } 24 \text { hours urinary excretion (dose } \\
\text { response curve). }\end{array}$ & \multicolumn{2}{|c|}{$\begin{array}{ll}\text { Avallability as measured by dose response } \\
\text { curves: } \\
\text { Bengal gram- } \\
\text { Green gram. } & 69 \% \\
\text { Tomato: } & 55 \% \\
\text { Spınach: } & 37 \% \\
\text { Banana: } & 63 \% \\
\text { Egg: } & 46 \% \\
\text { Liver: } & 72 \% \\
\text { Yeast: } & 70 \% \\
& 10 \%\end{array}$} & $\begin{array}{l}\text { There was considerable } \\
\text { variation in avallability } \\
\text { between the subjects. }\end{array}$ \\
\hline
\end{tabular}




\begin{tabular}{|c|c|c|c|}
\hline & Design & Results & Conclusions and comments \\
\hline $\begin{array}{l}\text { Sauberlich et } \\
\text { al } 1987\end{array}$ & $\begin{array}{l}\text { Human intervention study } \\
\text { Subjects } n=10 \text { healthy nonpregnant women } \\
\text { Design parallel/consecutive } \\
\text { No prior loadıng with folic acid } \\
\text { Treatment After a depletion period of } 28 \text { days } \\
\text { subjects received increasing amounts of food folate } \\
\text { or synthetıc folic acid } \\
\text { Measurement plasma and red blood cell folate } \\
\text { concentrations, lymphocyte deoxyuridine supression, } \\
\text { neutrophil segmentation and urinary folate excretion }\end{array}$ & $\begin{array}{l}\text { Plasma folate concentrations decreased } \\
60 \% \text { during the depletion period and } \\
\text { continued to decrease untıl subjects } \\
\text { received } 200 \mu g \text { of dietary folate per day } \\
\text { An amount of } 300 \mu g \text { of dietary folate was } \\
\text { sufficient to increase plasma folate slightly } \\
\text { Red blood cell folate concentrations still } \\
\text { continued to decrease Dietary folates } \\
\text { seemed to be no more than } 50 \% \\
\text { bioavallable compared to synthetic folic } \\
\text { acid }\end{array}$ & $\begin{array}{l}\text { This strictly controlled study } \\
\text { revealed that dietary folate } \\
\text { from a mixed diet was no } \\
\text { more than } 50 \% \text { broavallable } \\
\text { compared to folıc acid }\end{array}$ \\
\hline $\begin{array}{l}\text { Keagy, Shane } \\
\& \text { Oace, } 1988\end{array}$ & $\begin{array}{l}\text { Human intervention study } \\
\text { Subjects } n=7 \text { healthy young men } \\
\text { Desıgn All subjects received all treatments } \\
\text { Constant loading with } 500 \mu \text { g of folıc acıd per day } \\
\text { Treatment Four folate absorption tests were } \\
\text { conducted during the last four days of each } 9 \mathrm{~d} \\
\text { period in which subjects received either a formula, or } \\
\text { wheat bran, or white beans PteGlu and PteGlu7 } \\
\text { were given on alternate days during the absorption } \\
\text { tests } \\
\text { Measurement Increase in serum folate after } 1 \text { and } 2 \\
\text { hours and } 24 \text { hours urine excretion }\end{array}$ & $\begin{array}{l}\text { Adding wheat bran to the formula diet } \\
\text { increased the AUC for PteGlu PteGlu7 } \\
\text { was not affected by wheat bran Wheat } \\
\text { bran increased the absorption of PteGlu } \\
\text { relatıve to PteGlu7 whereas beans } \\
\text { minımised the difference between the AUC }\end{array}$ & $\begin{array}{l}\text { The enhancing effect of } \\
\text { wheat bran on PteGlu } \\
\text { bioavallability could be due } \\
\text { to endogenous folate of the } \\
\text { wheat bran or from } \\
\text { interactions of bran with } \\
\text { inhibitors of folate } \\
\text { absorption }\end{array}$ \\
\hline
\end{tabular}




\begin{tabular}{|c|c|c|c|}
\hline & Design & Results & Conclusions and comments \\
\hline $\begin{array}{l}\text { Balley et al } \\
1988\end{array}$ & 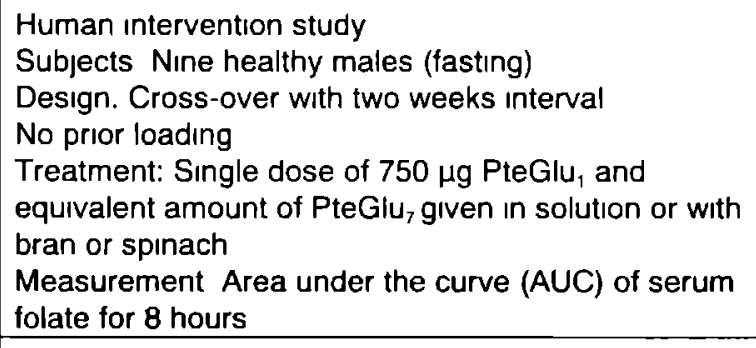 & $\begin{array}{l}\text { AUC's of PteGlu, and PteGlu, were not } \\
\text { different when ingested as solution or with } \\
\text { spinach. AUC for PteGlu, ingested with } \\
\text { bran was lower than PteGlu, ingested with } \\
\text { bran. }\end{array}$ & $\begin{array}{l}\text { This study suggests no } \\
\text { effect of chain length when } \\
\text { ingested as solution, but an } \\
\text { inhibiting effect of dietary } \\
\text { fibre on bioavailability of } \\
\text { PteGlu, compared to } \\
\text { PteGlu, }\end{array}$ \\
\hline $\begin{array}{l}\text { Cuskelly, } \\
\text { McNulty \& } \\
\text { Scott, } 1996\end{array}$ & $\begin{array}{l}\text { Human intervention study } \\
\text { Design Parallel (3 months) } \\
\text { Subjects: } 41 \text { women (5 groups). } \\
\text { No prior loadıng } \\
\text { Treatment: Subjects received either folic acid } \\
\text { supplements }(400 \mu / d) \text { or folıc acid fortified food } \\
\text { (additional } 400 \mu \mathrm{g} / \mathrm{d}) \text {, or dietary folate, or dietary } \\
\text { advice or nothıng (control) for three months } \\
\text { Measurement Red cell folate concentrations } \\
\end{array}$ & $\begin{array}{l}\text { Folic acid supplements and foods fortified } \\
\text { with folic acid both effectively increased red } \\
\text { blood cell folate concentrations, while food } \\
\text { folate had no significant effect on red blood } \\
\text { cell folate concentrations }\end{array}$ & $\begin{array}{l}\text { The study is based on small } \\
\text { numbers of women in each } \\
\text { group and the food and } \\
\text { tablet intake was not } \\
\text { controlled. However, intake } \\
\text { of dietary folate was } \\
\text { assessed by a validated } \\
\text { dietary assessment method. }\end{array}$ \\
\hline $\begin{array}{l}\text { Pfeiffer et al. } \\
1997\end{array}$ & $\begin{array}{l}\text { Human intervention study } \\
\text { Design: Cross-over. } \\
\text { Subjects: } 14 \text { adults. } \\
\text { No prior loading. } \\
\text { Treatment: } \\
\text { 1. Subjects received }\left[{ }^{13} \mathrm{C}_{5}\right] \text { folic acid in white bread, } \\
\text { whole wheat bread, rice or pasta or in solution } \\
\text { concurrently with }\left[{ }^{2} \mathrm{H}_{2}\right] \text { folic acid intravenously } \\
\text { 2. Subjects received }\left[{ }^{13} \mathrm{C}_{5}\right] \text { folic acid with or without a } \\
\text { light breakfast. } \\
\text { Measurement. Urinary excretion. } \%\left[{ }^{13} \mathrm{C}_{5}\right] \text { folate dose } \\
/ \%\left[{ }^{2} \mathrm{H}_{2}\right] \text { folate. }\end{array}$ & $\begin{array}{l}\text { The bioavailability of }\left[{ }^{13} \mathrm{C}_{5}\right] \text { folic acid in the } \\
\text { fortified products seemed lower than folic } \\
\text { acid in solution, but these differences were } \\
\text { not significantly different }(P=0607) \\
\text { The absorption of folic acid seemed slightly } \\
\text { lower when consumed after breakfast than } \\
\text { without food. This difference was also not } \\
\text { significant }(P<0.085) \text {. }\end{array}$ & $\begin{array}{l}\text { The bioavailability of } \\
{\left[{ }^{13} \mathrm{C}_{5}\right] \text { folic acid in fortified }} \\
\text { cereal grains was high. } \\
\text { The between subject } \\
\text { variation in this study was } \\
\text { high in comparıson to } \\
\text { studies using prior loading } \\
\text { with folic acid. The sensitivity } \\
\text { of this protocol was such that } \\
\text { only urinary excretion ratios } \\
\text { that were } 50 \% \text { of lower of } \\
\text { the control could be } \\
\text { detected. }\end{array}$ \\
\hline
\end{tabular}




\begin{tabular}{|c|c|c|c|}
\hline & Design & Results & Conclusions and comments \\
\hline $\begin{array}{l}\text { Brouwer et al } \\
1999\end{array}$ & $\begin{array}{l}\text { Human intervention study } \\
\text { Design Parallel, dietary controlled study ( } 4 \text { weeks) } \\
\text { Subjects } 66 \text { subjects ( } 22 \text { per group) } \\
\text { No prior loading } \\
\text { Treatment Subjects received either a diet with a } \\
\text { normal folate content plus placebo tablets dally } \\
\text { (placebo group), or a diet with the same folate } \\
\text { content plus } 500 \mu g \text { folic acid and placebo tablets } \\
\text { every other day (folic acid group), or a diet high in } \\
\text { folate (extra } 350 \mu \text { g/day, dietary folate group) } \\
\text { Measurement Change in plasma folate, red blood } \\
\text { cell folate and plasma total homocysteine }\end{array}$ & 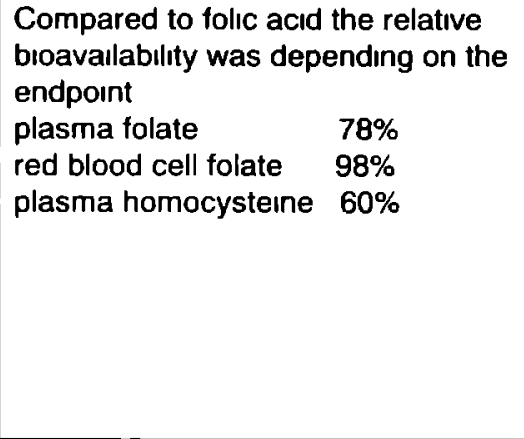 & $\begin{array}{l}\text { Folate from vegetables and } \\
\text { fruit decreased total plasma } \\
\text { homocysteine } \\
\text { concentrations and improved } \\
\text { the folate status The effects } \\
\text { are probably slightly } \\
\text { overestımated because folıc } \\
\text { acıd tablets were given every } \\
\text { other day instead of each } \\
\text { day }\end{array}$ \\
\hline
\end{tabular}




\section{Effect modifiers}

Effect modifiers are components in foods which influence the amount of a nutrient, folate, reaching the target organ. The effect of folate antagonists and other drugs will not be discussed in this review.

Since the intestinal brush border conjugase is zinc dependent, zinc can be expected to affect folate absorption. However, no studies investigating effects of zinc supplementation on the availability of dietary folate are available. Daily consumption of $3.5 \mathrm{mg}$ or $14.5 \mathrm{mg}$ of zinc in combination with folic acid supplementation for 25 days had no effect on the concentration of folate in serum, red blood cells and urine. This suggests that absorption of folic acid is not influenced by zinc intake (Kauwell et al., 1995).

Certain components in the food may have the ability to inhibit activity of the folate conjugase enzyme and thereby decrease the bioavailability of PteGlun. Tomatoes and orange juice inhibited the pteroylglutamate hydrolase (folate conjugase) activity in the human intestine (Bhandari and Gregory, 1990). Furthermore, citrate and to a lesser extent malate and formate, have been shown to affect intestinal brush border conjugase activity in vitro (Wei and Gregory, 1998). This suggests that organic acids affect the absorption of dietary polyglutamate folate by interfering with the intestinal deconjugation of the glutamate chain.

Alcohol could be another effect modifier. Folate deficiency is prevalent among chronic alcoholic patients which often have an inadequate dietary intake of minerals and vitamins. However, alcohol may also affect folate absorption (Halsted, 1995). In alcoholic pigs hydrolysis of pteroylpolyglutamates seems to be disturbed by intake of ethanol (Naughton et al., 1989; Reisenauer et al., 1989). This has not been confirmed in human studies although ethanol ingestion in five chronic alcoholic patients increased urinary excretion of folic acid (Russell et al., 1983). In combination with a diet deficient in folate, intake of ethanol decreased the uptake of folic acid in alcoholic subjects (Halsted et al., 1971). In normal, non-alcoholic, subjects ingestion of ethanol also decreased plasma folate concentrations (Eichner and Hillman, 1973). Thus, alcohol seems to affect folate bioavailability. 


\section{Nutrient status}

The folate, vitamın B12 and zinc status of the host might influence folate bioavailability Only a few studies investigated the effect of folate status on folate bıoavallability Babu \& Laksmaiah (1987) showed no effect of folate deficiency on jejunal conjugase activity in rats To our knowledge, there are no studies available comparing folate broavallability in folate deplete and folate replete subjects Although the study of Bower et al (1993) shows that the rise in serum folate after a pteroylpolyglutamate load (4 $5 \mathrm{mg}$ PteGlu7) is higher in subjects with higher serum folate compared to subjects with lower baselıne serum folate levels This might be explained by a longer circulation of folate in serum of replete subjects This would imply that in deplete subjects folate is rapidly removed from the serum to the tissues (Bower et al , 1993)

Distribution of folate over the tissues changes during folate deficiency Livers of folate deficient rats contain more polyglutamates of higher chain length than folate replete rats (Cassady et al, 1980, Varela-Moreiras and Selhub, 1992, Ward and Nixon, 1990) Folate concentrations decrease and chain length increases in liver, spleen and kidney in folate deficient rats, but both concentrations and chain length are the same in brain of folate deficient and folate replete rats (Richardson et al, 1979) Thus, folate status affects folate distribution over the tissues, but it is not clear whether it also affects folate bioavallability

Vitamin $B 12$ can influence folate bioefficacy since it is directly interrelated with folate Methylcobalamin serves as a co-factor for methionine synthase, the enzyme responsible for the remethylation of homocysteine into methionine In the same reaction is 5 -methyl-tetrahydrofolate demethylated into tetrahydrofolate (Savage and Lindenbaum, 1995) In cobalamin deficiency 5-methyltetrahydrofolate cannot be converted to tetrahydrofolate This lack of formation of tetrahydrofolate is named "the methyl folate trap" The lack of tetrahydrofolate has consequences for the formation of other folate coenzymes (Herbert and Zalusky, 1962) Although this theory has been criticised and many variations of the theory have been suggested (Savage and Lindenbaum, 1995), all these variatıons suggest that vitamın B12 deficiency influences folate bioefficacy because it changes the distribution of the different folate forms This influences also the overall folate status because tetrahydrofolate is a much better substrate than 5-methyltetrahydrofolate for the enzyme folate polyglutamate synthetase This enzyme is needed for formation of polyglutamates (Cichowicz and Shane, 1987a, Cichowicz and Shane, 1987b) Polyglutamyl folates 
are better retained in cells and are more effective co-enzymes than monoglutamyl folates (Lowe et al., 1993).

A sufficient supply of zinc is known to be important in folate bioavailability. Tamura et al. (1978) showed that zinc depletion reduced the rise in serum folate after supplementation with pteroylheptaglutamate by $53 \%$ while absorption of the monoglutamate form seemed unaffected. This suggested that intestinal pteroylpolyglutamate hydrolase is zinc dependent and that zinc depletion inhibits hydrolysis of polyglutamates. Chandler, Wang and Halsted (Chandler et al., 1986) confirmed the zinc dependency of the brush border folate hydrolase. Tamura reviewed in 1995 the literature concerning the nutrient interaction of folate and zinc. He concluded that although pteroylpolyglutamate hydrolase is zinc dependent its clinical significance is not clear.

\section{Genetic factors}

Some genetic mutations are known to influence folate metabolism. This section will discuss some common occurring genetic factors influencing folate bioavailability and efficacy.

In mice the RFC-1 gene expression regulates the $\mathrm{pH}$-dependent folate absorption in the small intestine (Chiao et al., 1997). The organisation and structure of the human RFC-1gene that encodes for a folate transporter is determined as well (Tolner et al., 1998). However, the significance of this gene for folate absorption needs further investigation.

Another gene that is linked to the folate status is the gene encoding for methylenetetrahydrofolate reductase (MTHFR). A variant of MTHFR was found to have lower specific activity and lower sensitivity to heat (Kang et al., 1988). This thermolabile variant is caused by an alanine-to-valine missense mutation (Goyette et al., 1994). Jacques et al. (1996) demonstrated that individuals homozygous for this mutation with lower plasma folate concentrations ( $<15.4 \mathrm{nmol} / \mathrm{L})$ had $24 \%$ higher fasting plasma total homocysteine concentrations than individuals with the normal genotype and similar plasma folate concentrations. No difference between genotypes was seen among individuals with plasma folate concentrations $\geq 15.4$ $\mathrm{nmol} / \mathrm{L}$. They suggested that individuals homozygous for this polymorphism need more folate to regulate their plasma homocysteine concentrations (Jacques et al., 1996). This implies that the bioefficacy of folate is diminished by this polymorphism when the folate status is not optimal. 
Methionine synthase is the enzyme involved in the remethylation reaction from homocysteine to methionine. To our knowledge, no polymorphisms in the gene encoding for the methionine synthase enzyme have been shown to influence the folate status or bioefficacy.

\section{Host-related factors}

Host-related factors are factors of the host besides the nutrient status and the genetic component that could influence bioavailability or bioefficacy. Examples of such factors are age, pregnancy, illness and malabsorption.

Bailey et al. (1984) investigated the absorption of poly- and monopteroylglutamates in different age groups. They found no indication that either the absorption or the activity of the folate conjugase was affected by age (Bailey et al., 1984).

Pregnancy increases the demand for folate. This higher demand can be explained by an accelerated folate breakdown (Kownacki Brown et al., 1993; McPartlin et al., 1993). However, Caudill et al. (1998) found in a dietary controlled trial no significant difference in catabolism between pregnant women and nonpregnant controls. Their study suggested that pregnant women made more efficient use of an amount of $450 \mu \mathrm{g}$ of folic acid than of $850 \mu \mathrm{g}$ of folic acid (Caudill et al., 1998). The same group (Caudill et al., 1997) found also no differences in serum folate or red blood cell folate response or in excretion of urinary 5-methylTHF after supplementation with $450 \mu \mathrm{g}$ and $850 \mu \mathrm{g}$ of folate per day. Thus, it is not clear what causes the higher demand for folate during pregnancy.

Two randomised trials showed that folic acid supplementation in the periconceptional period reduces the risk of having offspring with neural-tube defects (Czeizel and Dudás, 1992; MRC Vitamin Study Research Group, 1991). A decreased capability for the absorption of folate in the mother has been suggested as a cause for the folate-related cases of neural-tube defects. However, Bower et al. (1993) showed that intestinal hydrolysis of pteroylpolyglutamates was not impaired in women who previously had a child with a neural-tube defect. Moreover, Davis et al. (1995) found no difference in the absorption of folic acid between mothers with and without a history of a neural-tube defect. In contrast, Neuhouser et al. (1998) found that women who previously gave birth to a child with a neural-tube defect needed a larger dose of folic acid or folate to elicit a plasma response equivalent to the general 
population Thus, a dimınıshed bioavallability of folate in the mother could be a cause for neural-tube defects in their offspring

Halsted (1990) summarised studies from his group that investigated the effect of gastrointestinal diseases on the absorption of $\left[{ }^{3} \mathrm{H}\right]$ PteGlu and $\left[{ }^{14} \mathrm{C}\right] \mathrm{PteG} \mathrm{Hu}_{7}$ Absorption of $\left[{ }^{3} \mathrm{H}\right] \mathrm{PteGlu}$ and $\left[{ }^{14} \mathrm{C}\right] \mathrm{PteGlu}$, was not affected by ulcerative colitis However, uptake of both PteGlu and PteGlu, was dimınıshed in tropıcal and celiac sprue patıents

The saturable folate transport system in the jejunum is $\mathrm{pH}$ dependent Thus, folate bioavallability is $\mathrm{pH}$ dependent Folate transport has an acıdic $\mathrm{pH}$ optımum This subject has been extensively reviewed in the past (Halsted, 1979, Mason, 1990)

\section{Mathematical Interactions}

Mathematical interactions account for the difference in effect observed when two or more factors taken together have an effect that is different from the sum of the effect of the separate factors To our knowledge there are no articles in which this complicated problem has been studied

\section{Conclusion}

Various factors can influence bioavailability of nutrients. Of the factors influencing bioavailability of folate and folic acid two stand out in effect: the effect of the food matrix and the amount of folic acid consumed Bioavallability of folate from some foods is less than $50 \%$ of that of folic acid The most likely explanation for this would be matrix factors encapsulation and bınding However, matrix effects can often not be distinguished from other factors Other factors include the form and chain length of folate in food Food folate can have various one-carbon groups and these various folate forms can have a chain length of 1-7 glutamates Although some studies suggest that the form of folate affects bioavallability this seems to be only a minor factor Chain length might indeed affect bioavallability studies in this review suggest that polyglutamates have a lower bioavallabilty than monoglutamates However, we think that differences in chain length can explain at most half of the difference in bıoavallability between food folate and folic acid Bıavallabilty might also be influenced by other factors in food, such as organic acids. Indeed, organic acids 
Chapter 7

inhibited the conjugase responsible for the breakdown of polyglutamates into absorbable monoglutamates in vitro. This suggestion that organic acids decrease the bioavailability of folate has to be confirmed by in vivo studies. On the basis of the studies in this review we conclude that matrix is the main factor influencing bioavailability.

The amount of folic acid consumed seems to be a very important factor as well. The bioavailability of supplemental folic acid is good. However, the homocysteine-lowering capacity of doses of folic acid above $500 \mathrm{\mu g}$ is limited and it is not clear whether unmetabolised folic acid poses health risks. This is of importance; because food fortification is implemented in many countries nowadays and folic acid tablets are freely available.

In particular circumstances, host-related factors, such as illness and $\mathrm{pH}$ of the jejunum can influence bioavailability. Genetic factors also deserve our attention for future research. Mutations in certain genes might influence folate bioavailability. In this respect, we should not only search for mutations, but also investigate the clinical implication and possible therapies to overcome the negative impact of such mutations.

The present techniques used to measure bioavailability make quantification of the effect of the various factors very difficult. The accurateness of most techniques depends on a steady state situation in the body. To establish this, most studies have used a folic acid preloading scheme to saturate tissues with folic acid. Saturation of the tissues reduces the intra-individual variation in the responses to treatment. However, it is not clear how this affects bioavailability. Therefore, further development of techniques such as the stable isotope techniques is needed.

In conclusion, food matrix and the amount of folic acid consumed are the major factors influencing bioavailability in healthy people. Food manufacturers can play an important role in increasing the bioavailability. Development of new food preparation methods could change the food matrix in a way that folate will be more bioavailable. Many people do not consume sufficient folate (Brussaard et al. 1995). Better bioavailability of food folate would make it easier for people to reach a sufficient level of intake. Folate status can also be improved by increasing the intake of folic acid. This could be established by consumption of foods fortified with folic acid and of folic acid tablets. However, intakes above $500 \mu \mathrm{g}$ per day have no additional improving effect on the functional parameter of folate status, plasma total homocysteine concentrations. Moreover, it is unclear whether such doses pose health risks. Therefore, intakes of high doses of folic acid should be avoided. 
8

General Discussion 


\section{Folic acid, folate and homocysteine}

This thesis describes intervention studies with low doses of supplemental folic acid and dietary folate. The effects of supplementation with low doses of folic acid on folate status and plasma total homocysteine concentrations in healthy volunteers and spina bifida patients are discussed. Bioavailability of food folate is the next issue.

The main conclusions, recommendations and possibilities for future research are presented and the thesis ends with the concluding remarks.

\section{Low-dose folic acid supplementation}

\section{Healthy volunteers}

Intervention studies with healthy young women with normal baseline levels of total plasma homocysteine (Chapters 2, 3 and 4) show that supplementation with low doses of folic acid improves the folate status and decreases total plasma homocysteine concentrations. Previous research had shown that supplementation with high doses of folic acid, often in combination with other vitamins and minerals, improved folate status and decreased total plasma homocysteine concentrations. Most of the earlier studies focused on subjects with hyperhomocysteinemia (Franken et al., 1994; Naurath et al., 1995; Ubbink, 1997; Ubbink et al., 1994; van den Berg et al. 1994). The studies described in Chapters 2,3 and 4 and the Homocysteine Lowering Trialists' (1998) showed that supplementation with doses of folic acid between 250 and $500 \mu \mathrm{g}$ per day can also decrease plasma total homocysteine concentrations in healthy people with homocysteine concentrations in the normal range.

Our study investigating effects of low doses of folic acid (Chapter 2) and the study of Ward et al. (1997) showed that the extent of decrease in total plasma homocysteine concentrations depends on the baseline concentration of total plasma homocysteine. Higher baseline concentrations of total plasma homocysteine result in a more dramatic decrease in total plasma homocysteine after folic acid supplementation than lower baseline concentrations (Brouwer et al., 1999; Ward et al., 1997). In our study, the effect could not be due to regression to the mean because it was not shown in the placebo group.

Folic acid supplementation is most likely to stimulate the remethylation from homocysteine into methionine because 5-methyltetrahydrofolate is the methyl donor 
In this reaction (Ueland et al, 1993) Therefore, an ıncrease in plasma methionıne concentratıons could have been expected after folıc acid supplementation However, our study (Chapter 3 ) could not show such an increase In contrast, Guttormsen et al (1996b) showed an increase in plasma methionine after supplementation with folic acid or injections with vitamın B12 However, the subjects in that study were deficient in either folate or vitamın B12 and used a much higher dose of folic acid (Guttormsen et al , 1996b) Thus, the discrepancy in results might be due to the dose of folic acid used in our study $(500 \mu \mathrm{g} / \mathrm{d}$ or $500 \mu \mathrm{g}$ every other day) and the fact that the subjects were in a good vitamın status However, with respect to plasma total homocysteıne the status of our subjects seemed not optımal because folic acid did decrease their plasma total homocysteıne concentrations

Kelly et al (1997) showed that unmetabolised folic acid appears in serum after ingestion of a dose of folic acid of more than $266 \mu \mathrm{gg}$ The study described in Chapter 4 suggests that $250 \mu \mathrm{g}$ folic acıd taken each day decreases plasma total homocysteine more effectively than $500 \mu \mathrm{g}$ folic acid taken every other day This observation together with the findings of Kelly et al (1997) Indicates that unaltered folıc acid has no homocysteine lowering capacity Therefore, low doses of folic acid should be recommended to be taken each day or divided over the day (food fortification) to lower plasma total homocysteıne concentrations

\section{Spina Bifida patients}

In Chapter 5 were no apparent differences between spina bifida and disabled control subjects in plasma and red blood cell folate, in plasma vitamın B12 or plasma total homocysteıne concentrations at baselıne The outcomes of earlier studies were not conclusive with respect to differences in plasma total homocysteine concentrations in patients with a neural-tube defect and control subjects Some studies showed higher fasting plasma total homocysteıne concentratıons in spına bifida than in control subjects (Bృørke-Monsen et al, 1997, van der Put et al, 1997b), whereas other studies found no significant differences in the folate and vitamın B12 status of foetuses affected with a neural-tube defect (Bundukı et al, 1995, Economides et al, 1992, Thorand et al, 1996) Bjørke-Monsen et al (1997) showed that the differences in total plasma homocysteıne concentratıons between the spına bifida and the control group were confined to those patients with one or two C677T. mutated alleles in the methylenetetrahydrofolate reductase gene Furthermore, plasma total homocysteıne concentrations are only increased in those subjects homozygous for the C677T mutation with a plasma folate concentration lower than $154 \mathrm{nmol} / \mathrm{L}$ (Jacques et al , 1996) Thus, a sufficient intake of folate can counteract 
the increased risk of the C677T mutation. Repeating the statistical analysis with exclusion of those subjects with two mutated C677T alleles did not change the outcome of our study (Chapter 5).

Our study (Chapter 5) is the first to investigate effects of four weeks of supplementation with $500 \mu \mathrm{g}$ of folic acid per day on plasma total homocysteine concentrations in spina bifida patients. This intervention strategy seemed as effective in lowering plasma total homocysteine concentrations and improving the folate status in spina bifida patients as in control subjects. We have no indication that an impaired folate and homocysteine metabolism in spina bifida patients is an important cause for their neural-tube defect. Therefore, our study (Chapter 5) provides no new insights on the mechanism by which inadequate supply of folate causes spina bifida. We suggest that either a higher need for folic acid in the mother, or a defect in intrauterine folate transport from mother to child are more important causes for neuraltube defects than a defect in the homocysteine metabolism of the affected child itself.

\section{Bioavailability of folate}

In Chapter 2 we show that it is possible to decrease plasma total homocysteine concentrations with low doses of folic acid in healthy volunteers. This suggested that there could be possibilities for successful lowering of plasma total homocysteine concentrations with dietary folate. A controlled dietary experiment (Chapter 6 ) shows that dietary folate can improve the folate status and decrease plasma total homocysteine concentrations in healthy volunteers. In contrast, Cuskelly et al. (1996) found no significant improvement of red blood cell folate concentrations after 3 months of intervention with dietary folate. However, our study focused on folate from vegetables and citrus fruit only whereas the study of Cuskelly et al. (1996) used a broader range of folate rich products. Besides, Cuskelly et al. (1996) studied whether supplying subjects with folate rich foods in the free living situation would improve their folate status, whereas our study is an efficacy study. This implied that the diets were much stricter controlled. In addition, the study in Chapter 6 consisted of 22 subjects per group instead of no more than 10 per group in the study of Cuskelly et al. (1996). Sauberlich et al. (1987) concluded from changes in plasma folate in healthy volunteers in a very strictly controlled trial that the bioavailability of folate from a mixed diet was no more than $50 \%$. We found in our study, folate from vegetables and citrus fruit to be between 60 and $98 \%$ bioavailable compared to the 
folic acid treatment. The bioefficacy, using changes in total plasma homocysteine as endpoint, was $60 \%$. The bioavailability was $78 \%$ for changes in plasma folate, and $98 \%$ for changes in red blood cell folate concentrations. However, in this dietary intervention study we supplied folic acid tablets every other day instead of each day. The study in which tablets were taken every day versus a double dose every other day (Chapter 4) suggests that $250 \mu \mathrm{g}$ folic acid taken each day more effectively decreases plasma total homocysteine than $500 \mu \mathrm{g}$ of folic acid taken every other day. Therefore, we might have underestimated the effect of folic acid in our controlled dietary experiment (Chapter 6 ). By doing so we overestimated the relative bioavailability of dietary folate from vegetables and citrus fruit. Even though, the results of Chapter 6 show that dietary folate from vegetables and citrus fruit improved the folate status and decreased plasma total homocysteine concentrations in healthy volunteers.

Chapter 6 and other studies suggest that food folate is less bioavailable than folic acid (Cuskelly et al., 1996; Sauberlich et al., 1987). Many studies have investigated factors affecting the bioavailability of folate. These studies are reviewed in Chapter 7. Two factors stand out in effect on folate bioavailability: food matrix and amount of folic acid consumed. The length of the glutamate chain of the folate molecule is likely to play a role as well. Polyglutamates seem to be less bioavailable than monoglutamates.

The present techniques used to measure bioavailability make quantification of the effects of the various factors difficult. Therefore, further development of techniques, such as stable isotope techniques will be very useful for future research. 


\section{Main conclusions}

The main conclusions from the intervention studies are the following:

- Low-dose folic acid supplementation (250 or $500 \mu \mathrm{g} /$ day) improves folate status and decreases total plasma homocysteine concentrations in healthy subjects.

- The homocysteine and folate metabolism of spina bifida patients does not appear to differ drastically from control patients. Although the C677T mutation in the methylenetetrahydrofolate reductase gene may contribute to the occurrence of neural-tube defects. Furthermore, supplementation with low-doses of folic acid seems as effective in spina bifida patients as in control subjects.

- Dietary folate from vegetables and citrus fruit also has the potential to improve the folate status and to lower total plasma homocysteine concentrations. The relative effect on plasma total homocysteine (bioefficacy) of dietary folate from vegetables and citrus fruit was $60 \%$. The relative bioavailability was $78 \%$ for changes in plasma folate and $98 \%$ for changes in red blood cell folate. 


\section{Implications}

\section{Folic acid/folate for the prevention of neural-tube defects}

Earlier studies have clearly shown that additional folic acid taken in the period around the conception lowers the risk of having offspring with a neural-tube defect (Czeizel and Dudas, 1992, MRC Vitamın Study Research Group, 1991) Other studies suggest that elevated homocysteine concentrations are a risk factor for having offspring with a neural-tube defect (Mills et al , 1995, Steegers Theunissen et al , 1994) We showed that additional dietary folate from vegetables and citrus fruit, as well as low-doses of folic acid decrease total plasma homocysteine concentrations in healthy volunteers in spite of this finding, women planning to become pregnant should still be advised to take 400 to $500 \mu \mathrm{g}$ of synthetic folic acid in addition to their habitual diet from at least four weeks before conception until the eighth week of pregnancy (Food and Nutrition Councll, 1993)

There are a few reasons why this advice to take supplemental folic acid is still valid Firstly, synthetic folic acid has in randomised trials been proven to prevent neural-tube defects (Czeızel and Dudas, 1992, MRC Vitamın Study Research Group, 1991) Dietary folates may prevent neural-tube defects, but have not been proven to do so Some investıgators even report a dimınished absorption of dietary folate in women with prior pregnancies with a neural-tube defect (Neuhouser et al, 1998) It is also no longer possible to test whether a high intake of dietary folate prevents neural-tube defects because it would be unethical to withhold folic acid from women in the critical period around the conception For the same ethical reasons it also no longer possible to investigate the minımal daily dose of folic acid that prevents neural-tube defects Secondly, the Netherlands Food and Nutrition Council advises women planning to become pregnant to take 400 to $500 \mu \mathrm{g}$ of folic acid dally in addition to the dietary intake (Food and Nutrition Counci, 1993) Therefore, even if a higher intake of dietary folate would also be effective in preventıng neural-tube defects, it would be very hard for women to take an equivalent amount of folate with their diet Thirdly, intake of folic acid in the right period is expected to prevent more than $50 \%$ of the neural-tube defect cases (MRC Vitamın Study Research Group, 1991) The underlying mechanism of these folic acid preventable neural-tube defects is not clear The homocysteine-lowering potential of folic acid might play a role in some cases, but other factors may play a role as well Therefore, although we show that dietary folate decreases plasma total homocysteıne concentrations, it does not prove that neural-tube defects can be prevented in this manner 
On the other hand, although women are advised to take additional folic acid in the period around conception this advice is not always followed (de Jong-van den Berg et al., 1998; Sayers et al., 1997). For women who do not take extra folic acid it may be worthwhile to take as much dietary folate as possible. To increase the chance that women who become pregnant receive sufficient folic acid to prevent neural-tube defects, the US government has decided to fortify flour with folic acid (US Department of Health and Human Services.Food and Drug Administration, 1996).

Vegetables and fruit are not only good sources of folate, they also have other health promoting components. Therefore, women planning to become pregnant should be advised to take 400 to $500 \mu \mathrm{g}$ of folic acid and to follow the dietary guidelines as suggested by the Netherlands Health and Nutrition Council (Food and Nutrition Council, 1993; Voedingsraad, 1992). These guidelines include an advice to eat at least 200 grams of vegetables and 2 servings of fruit Noedingsraad, 1992).

\section{Folic acid/folate for the prevention of cardiovascular disease}

Patients with cardiovascular diseases have been shown to have higher total plasma homocysteine concentrations than healthy control subjects (Clarke et al., 1991; den Heijer et al., 1996; Falcon et al., 1994; Pancharuniti et al., 1994; Selhub et al., 1995; Stampfer et al., 1992). Furthermore, the relationship between plasma total homocysteine and cardiovascular disease seems to be graded with no apparent threshold (Refsum et al., 1998). Moreover, an elevated plasma total homocysteine concentration is besides a strong independent risk factor an even stronger risk factor in combination with the established risk factors smoking and hypertension (Graham et al., 1997). Intervention studies have shown that supplementation with folic acid lowers plasma total homocysteine concentrations (Chapter 2 and 4 of this thesis, (Homocysteine Lowering Trialists' Collaboration, 1998; Ward et al., 1997). Therefore, an elevated plasma total homocysteine concentration seems an important risk factor that can easily be treated with low doses of B-vitamins. However, studies investigating whether homocysteine lowering therapies decrease the risk of cardiovascular disease have not been published, but are currently underway. Therefore, it is too early to advise the whole population to take extra folic acid daily. Of course, the whole population should still be advised to eat according to the dietary guidelines of the Food and Nutrition Council (Voedingsraad, 1992). This implies a sufficient intake of fruits and vegetables. Fruits and vegetables are good sources of folate which help to decrease plasma total homocysteine concentrations in healthy volunteers (Chapter 6). Lowering of plasma total homocysteine concentrations might 
decrease the risk of cardiovascular disease. Besides, fruits and vegetables contain other health promoting factors.

\section{Future studies}

\section{Neural-tube defects}

Folic acid supplementation in the period around conception prevents neural-tube defects. However, the question, how and why folic acid prevents the neural-tube defects is very hard to answer, especially because placebo controlled trials cannot be executed anymore for ethical reasons. Therefore future research on the issue of folate and neural-tube defects should focus on:

- The development of a good animal model for the aetiology of the neural-tube defect. Such a model would be an enormous step forward. However, a main drawback of such a model is that the results cannot always be transferred to human beings (Barber et al., 1998). Of course, good in vitro models can also provide important new insights.

- The search for other genetic mutations, besides the MTHFR C677T mutation, that might have a relationship with neural-tube defects. In this search it is important to not only detect the mutation, but also to investigate the clinical implications of the mutation and whether therapy can overcome the negative impact of the mutation.

\section{Cardiovascular disease}

The relationship between cardiovascular disease, folate and homocysteine is the next issue to be solved. Do homocysteine-lowering intervention therapies indeed decrease the risk of cardiovascular disease? Trials investigating this issue are currently underway. Unfortunately, it will take at least 4 or 5 more years before results of these trials will be available. Many of these trials are performed in countries where folic acid fortified food products are available. This implies that subjects in the placebo group will receive folic acid from these foods. Chapter 7 (Amount of folate) suggests that the first 100 or $200 \mu \mathrm{g}$ of folic acid are expected to lower homocysteine concentrations most effectively. Therefore, trials executed in countries where fortified foods are available are at risk of finding a null effect. Thus, it is important that trials will also be performed in countries, such as the Netherlands, where folic acid fortified foods are not on the market.

Further research in the field of folate, homocysteine and cardiovascular disease should focus on: 
- The dose response relationship between the vitamins involved in the homocysteine metabolism and plasma total homocysteine concentrations. It is important to find the lowest dose that effectively lowers plasma total homocysteine especially because the effects of unmetabolised folic acid in the blood are unknown (Kelly et al., 1997)

- The investigation of other homocysteine-lowering therapies than supplementation with folic acid. Some studies have investigated effects of vitamin B6 and vitamin B12 mainly in combination with folic acid (Ubbink, 1997). However, very few studies have investigated effects of riboflavin, which donates a prosthetic group to methylenetetrahydrofolate reductase, or betaine, which is involved in the alternate remethylation pathway (homocysteine into methionine).

- The aetiology of the relationship between homocysteine and cardiovascular disease. Even if intervention with folic acid decreases the risk of cardiovascular disease, the question remains whether homocysteine is the causal factor or just an intermediary factor. However, if other homocysteine-lowering therapies would also decrease the risk of cardiovascular disease this would indicate a causal relationship.

\section{Concluding remarks}

Intake of low doses of folic acid in addition to the habitual diet and a high intake of dietary folate from vegetables and citrus fruits improves the folate status and decreases plasma total homocysteine concentrations in healthy people. This may lower the risk of having offspring with a neural-tube defect and cardiovascular diseases. The fact that this can be established by intake of folate from vegetables and citrus fruits provides another argument for advising the general population to increase their intake of vegetables and fruits. However, women planning to become pregnant should still take supplemental folic acid as well. Folate from foods may prevent neural-tube defects, but folic acid supplements have been proven to prevent these defects.

We found no indication that an impaired folate and homocysteine metabolism in spina bifida patients is an important cause for their neural-tube defect. We suggest that either a higher need for folic acid in the mother, or a defect in intra-uterine folate transport from mother to child are more important causes for neural-tube defects than a defect in the homocysteine metabolism of the affected child itself. 


\section{References}

Andersson, A, Brattstrom, L, Israelsson, B, Isaksson, A, and Hultberg, B (1990) The effect of excess dally methıonine intake on plasma homocysteıne after a methıonıne loadıng test In humans Clin Chım Acta 192, 69-76

Arakı, A and Sako, $Y$ (1987) Determınation of free and total homocysterne in human plasma by high performance liquid chromatography with fluorescence detection $J$ Chromatogr $\mathbf{4 2 2}$, 43-52

Armstrong, M D and Stave, U (1973) A study of plasma free amıno acid levels II Normal values for children and adults Metabolism 22, 561-569

Babu, S and Lakshmaiah, N (1987) Avallability of food folate by liver folate repletion in rats Nutr Reports Int 35, 831836

Babu, S and Srikantia, S G (1976) Avallability of folates from some foods Am J Clin Nutr 29, 376-379

Bailey, LB, Barton, LE, Hillier, SE, and Cerda, J J (1988) Bıoavallability of mono and polyglutamyl folate in human subjects Nutr Reports Int 38, 509-518

Barley, L B , Cerda, J J, Bloch, B S, Busby, M J, Vargas, L, Chandler, C J, and Halsted, C H (1984) Effect of age on poly-and monoglutamyl folacin absorption in human subjects $J$ Nutr 114, 1770-1776

Barber, R C , Shaw, G M , Lammer, E J, Greer, KA, Biela, T A, Lacey, S W, Wasserman, $\mathrm{C}$, and Finnell, $\mathrm{RH}$ (1998) Lack of association between mutation in the folate receptor-alpha gene and spina bifida Am J Med Genet 76, 310-317

Bhandarı, S D and Gregory, JF (1990) Inhibition by selected food components of human and porcine intestınal pteroylpolyglutamate hydrolase activity Am J Clın Nutr 51, 87-94

Bhandarı, SD and Gregory, JF (1992) Folıc acıd, 5-methyl-tetrahydrofolate and 5-formyltetrahydrofolate exhıbit equivalent intestinal absorption, metabolism and in vivo kinetics in rats $J$ Nutr 122, 1847-1854

Bjørke-Monsen, A L, Ueland, P M , Schneede, J, Vollset, S E , and Refsum, H (1997) Elevated plasma total homocysteine and C677T mutation of the methylenetetrahydrofolate reductase gene in patients with spina bifida QJM 90, 593-596

Bonnette, RE, Caudıll, MA, Boddle, A M, Hutson, AD, Kauwell, GPA, and Bailey, LB (1998) Plasma homocyst(e)ine concentrations in pregnant and nonpregnant women with controlled folate intake Obstet Gynecol 92, 167-170

Boushey, C J, Beresford, S A, Omenn, G S, and Motulsky, A G (1995) A quantitative assessment of plasma homocysteine as a risk factor for vascular disease Probable benefits of increasing folic acid intakes JAMA 274, 1049-1057

Bower, C , Stanley, F J , Croft, M , de Klerk, N, Davis, R E, and Nicol, D J (1993) Absorption of pteroylpolyglutamates in mothers of infants with neural tube defects $\operatorname{Br} J$ Nutr 69, 827 . 834 
Brants, HAM and Hulshof, KFAM (1995) De ontwikkeling van een voedingsmiddelentabel met foliumzurgehaltes (development of a food table with folic acid values), Zeist, the Netherlands, TNO-Nutrition

Brattstrom, LE, Israelsson, B, Jeppsson, JO, and Hultberg, B L (1988) Folic acid--an Innocuous means to reduce plasma homocysteine Scand J Clin Lab Invest 48, 215-221

Brouwer, I A, van Dusseldorp, M, Thomas, C M G, Duran M, Hautvast, J G A J, Eskes, T K A B , and Steegers Theunissen, R P M (1999) Low-dose folic acid supplementation decreases plasma homocysteıne a randomized trial Am J Clin Nutr 69, 99-104

Brown, J P . Scott, J M , Foster, F G , and Weir, D G (1973) Ingestion and absorption of naturally occurring pteroyimonoglutamates (folates) in man Gastroenterology 64, 223-232

Brussaard J $H$, van den Berg $H$, Brants $H A M$, van Loon $C J A M$, and Lowik, MR H Folate intake and status among adults in the Netherlands (Dutch Nutrition Survellance System) Descriptive Statistics, Zeist, the Netherlands, TNO-Nutrition

Bundukı, V, Dommergues, M, Zittoun, J, Marquet, J, Muller, F, and Dumez, $Y$ (1995) Maternal-fetal folate status and neural tube defects a case control study Biol Neonate 67, 154-159

Campbell, N R C (1996) How safe are folıc acıd supplements? Arch Intern Med 156, 1683-1644

Cassady, I A, Budge, M M , Healy, M J , and Nixon, P F (1980) An inverse relationship of rat Iiver folate polyglutamate chain length to nutritional folate sufficiency Biochim Biophys Acta 633, 258-268

Caudill, M A, Cruz, A C , Gregory, JF, Hutson, A D, and Bailey, L B (1997) Folate status response to controlled folate intake in pregnant women $J$ Nutr 127, 2363-2370

Caudill, M A , Gregory, J F , Hutson, A D , and Balley, L B (1998) Folate catabolism in pregnant and nonpregnant women with controlled folate intakes J Nutr 128, 204-208

Centers for Disease Control (1992)' Recommendations for the use of folic acid to reduce the number of cases of spina bifida and other neural tube defects Morbıd Mortal Weekly Rep 41, 1-7

Chandler, C J, Wang XL, and Halsted, $\mathrm{CH}$ (1986) Pteroylpolyglutamate hydrolase from human jejunal brush borders, purification and characterization $J$ Biol Chem 261, 928933

Chiao, J H , Roy, K, Tolner, B, Yang, C -H, and Sirotnak, F M (1997) RFC-1 gene expression regulates folate absorption in mouse small intestıne J Biol Chem 272, 11165-11170

Cichowicz DJ and Shane, B (1987a) Mammalian folylpoly-gamma-glutamate synthetase 1 Purification and general properties of the hog liver enzyme Biochemistry 26, 504-512

Cichowicz, D J and Shane, B (1987b) Mammalian folylpoly-gamma-glutamate synthetase 2 Substrate specificity and kınetic properties Biochemistry 26, 513-521

Clarke, R, Daly, LE, Robınson, K, Naughten, E, Cahalane, S, Fowler, B , and Graham. I (1991) Hyperhomocysteinemia An independent risk factor for vascular disease $N$ Engl J Med 324, 1149-1155 
Colman, $N$ (1982) Addition of folic acid to staple foods as a selective nutrition intervention strategy Nutr Rev 40, 225-233

Colman, N , Green, R, and Metz, J (1975) Prevention of folate deficiency by food fortification II. Absorption of folic acid from fortified staple foods Am J Clin Nutr 28, 459-464

Cuskelly, G J , McNulty, H , and Scott, J M (1996) Effect of increasing dietary folate on red-cell folate implications for prevention of neural tube defects Lancet 347, 657-659

Czeizel, A E and Dudás, I (1992) Prevention of the first occurrence of neural-tube defects by perıconceptional vitamın supplementation N Engl J Med 327, 1832-1835

Davis, B A, Balley, L B , Gregory, J F, Toth, J P, Dean, J, and Stevenson, R E (1995) Folic acid absorption in women with a history of pregnancy with neural tube defect $A m J \mathrm{Clin}$ Nutr 62, 782-784

de Bree, A, van Dusseldorp, M Brouwer, I A, van het Hof, $\mathrm{KH}$, and Steegers Theunissen, R P M (1997) Folate intake in Europe recommended, actual and desıred intake Eur $J$ Clin Nutr 51, 643-660

de Jong-van den Berg, $L T$, de Walle, HE, van der Pal-de Bruın, KM, Buitendık, SE, and Cornel, M C (1998) Increasing awareness of and behaviour towards periconceptional folıc acid consumption in The Netherlands from 1994 to 1995 Eur J Clin Pharmacol 54, 329-331

de Pee, S and West, CE (1996) Dietary carotenoids and theır role in combatıng vitamin A deficiency a review of the literature Eur J Clin Nutr 50 Suppl 3, \$38-S53

den Heljer, M , Brouwer, I A , Bos, G J , Blom, H J , van der Put, N M , Spaans, A P , Rosendaal, F R, Thomas, C G, Haak, HL, Wijermans, PW, and Gerrits, W J (1998) Vitamın supplementation reduces blood homocysteine levels - A controlled trial in patients with venous thrombosis and healthy volunteers Arterioscler Thromb Vasc Bıol 18, 356-361.

den Heijer, M , Koster, T, Blom, H J , Bos, G M , Briet, E , Reitsma, P H , Vandenbroucke, J P . and Rosendaal, FR (1996) Hyperhomocysteinemia as a risk factor for deep-vein thrombosis N Engl J Med 334, 759-762

Dierkes, J (1995) Vitamin requirements for the reduction of homocysteme in healthy young women (thesis), Giessen, Germany, Wissenschaftlichen Fachverlag Dr Fleck

Dierkes, J , Kroesen, M , and Pietrzık, K (1998) Folıc acıd and vitamın B6 supplementation and plasma homocysteine concentrations in healthy young women Internat $J$ Vit Nutr Res 82 , 98-103

Dutch Heart Foundation (1997) Cardiovascular diseases in the Netherlands Morbidity and mortality statistics, The Hague, Dutch Heart Foundation

Economides, D L, Ferguson, J, Mackenzıe, I Z, Darley, J, Ware, 11, and Holmes-Siedle, M (1992) Folate and vitamın B12 concentrations in maternal and fetal blood, and amniotic fluid in second trimester pregnancies complicated by neural tube defects $\mathrm{Br} J$ Obstet Gynaecol 99, 23-25

Eıchner, E R and Hillman, R S (1973) Effect of alcohol on serum folate level J Clin Invest 52, 584-591 
EUROCAT Workıng Group (1998) EUROCAT regıstration of congenital anomalıes. Northern Netherlands and Southwestern Netherlands. Tables 1981-1996., Gronıngen, Department of Medical Genetıcs, Unıversity of Gronıngen.

Expert Advisory Group (1992) Folic acid and the prevention of neural tube defects, London, Department of Health.

Falcon, C.R, Cattaneo, M., Panzerı, D., Martınellı, I., and Mannuccı, P.M. (1994) Hıgh prevalence of hyperhomocyst(e)ınemia in patıents with juvenile venous thrombosis. Arterioscler Thromb 14, 1080-1083

FAO (1988) Requirements of vitamın A, iron, folate and vitamın B12. Report of a joint FOAWHO Expert Consultation. in. FAO Food and Nutrition Series, Rome,

Feunekes, G I.J., van Staveren, W.A., de Vries, J.H M., Burema, J., and Hautvast, J.G.A.J. (1993) Relative and biomarker-based valıdity of a food-frequency questionnaire estımatıng intake of fats and cholesterol Am J Clin Nutr 58, 489-496.

Fınkelsteın, J D. (1990) Methıonine metabolısm in mammals. J Nutr Biochem 1, 228-237.

Fiskerstrand, T., Refsum, H., Kvalheım, G., and Ueland, P M. (1993) Homocysteine and other thıols in plasma and urıne. automated determınatıon and sample stability. Clin Chem 39 , 263-271.

Food and Nutrition Council (1992) Report on the relationship between folic acid and neural tube defects, The Hague. Food and Nutrition Councll.

Food and Nutrition Council (1993) Follow-up report on the relationship between folic acid intake and neural tube defects, The Hague, Food and Nutrition Council

Franken, D G., Boers, G H.J., Blom, H.J., Trıbels, F.J., and Kloppenborg, P.W. (1994) Treatment of mild hyperhomocysteinemia in vascular disease patients Arterioscler Thromb 14, 465 470

Frosst, P., Blom, H J., Milos, R., Goyette, P., Sheppard, C.A., Matthews, R G., Boers, G.J., den Heıer, M., Kluıtmans, L.A., van den Heuvel, L.P., and Rozen, R (1995) A candidate genetıc risk factor for vascular disease: a common mutation in methylenetetrahydrofolate reductase Nat Genet 10, 111-113.

Gardıkı-Kouidou, P and Seller, M.J (1997) Amniotıc fluid folate, vitamin B12 and transcobalamın in neural tube defects Clin Genet 33, 441-448.

Gıles, W.H., Kittner, S.J., Anda, R F., Croft, J.B., and Casper, M.L. (1995) Serum folate and risk for Ischemic stroke. First Natıonal Health and Nutritıon Examınatıon Survey epıdemıologic follow-up study. Stroke 26, 1166-1170.

Godwin, H.A and Rosenberg, IH (1975) Comparative studies of the intestinal absorption of $[3 \mathrm{H}]$ pteroyimonoglutamate and $[3 \mathrm{H}]$ pteroylheptaglutamate in man. Gastroenterology 69 , 364-373.

Goyette, P., Sumner, J.S., Mılos, R., Duncan, A M, Rosenblatt, D.S., Matthews, R.G., and Rozen, R (1994) Human methylenetetrahydrofolate reductase: isolation of cDNA mapping and mutation identification Nat Genet 7, 551-55s. 
Graham, I M , Daly, LE, Refsum, H M , Robınson, K, Brattstrom, LE, Ueland, P M, PalmaReIs, A J , Boers, G H J, Sheahan, R G, Israelsson, B, Uiterwaal, C S, Meleady, R, McMaster, D , Verhoef, P , Witteman, J , Rubba, P, Bellet, H, Wautrecht, J C, de Valk, HW, Sales LuIs, A C , Parrot-Roulaud, F M, Soon Tan, K, Higgıns, I, Garcon, D, Medrano, M J , Candito, M , Evans, A E, and Andria, G (1997) Plasma homocysteine as a risk factor for cardiovascular disease JAMA 277, 1775-1781

Green, T J, Houghton, LA, Donovan, U M, Gıbson, R S, and O'Connor, D L (1998) Oral contraceptives did not affect biochemical folate indexes and homocysteine concentrations in adolescent females J Am Diet Assoc 98, 49-55

Gregory. J F, Bhandarı, S D, Bailey, L B, Toth, J P , Baumgartner, T G , and Cerda, J J (1991) Relative bioavailability of deuterium-labeled monoglutamyl and hexaglutamyl folates in human subjects Am J Cln Nutr 53, 736-740

Gregory, J F , Bhandarı, S D , Bailey, L B , Toth, J P , Baumgartner, T G , and Cerda, J J (1992) Relative bioavailability of deuterıum-labeled monoglutamyl tetrahydrofolates and tolic acıd in human subjects Am J Clin Nutr 55, 1147-1153

Guttormsen, A B , Schneede, J, Ueland, P M, and Refsum, H (1996b) Kinetics of total plasma homocysteine in subjects with hyperhomocysteınemı due to folate or cobalamın deficiency Am J Clin Nutr 63, 194202

Guttormsen, A B, Ueland, PM, Nesthus, I, Nygard, O, Schneede, J, Vollset, S E, and Refsum, $H$ (1996a) Determınants and vitamın responsiveness of intermediate hyperhomocysteınemı ( $<=40 \mathrm{mu}$ mol/Iter) - The Hordaland homocysteine study J Clin Invest 98, 2174-2183

Halsted, C H (1979) The intestınal absorption of folates Am J Clin Nutr 32, 846-855

Halsted, $\mathrm{CH}$ (1990) Intestınal absorption of dietary folates In Folic acid metabolism in health and disease, 23-45 Edited by PIcciano, M F, Stokstad E L R, and Gregory, J F , New York, Wiley-Liss

Haisted, C H (1995) Alcohol and folate interactıons Clinical implications In Folate in health and disease, 313-327 Edited by Balley, L B, New York, Marcel Dekker Inc

Halsted, CH, Baugh, CM, and Butterworth-Jr, CE (1975) Jejunal perfusion of simple and conjugated folates in man Gastroenterology 68, 261269

Halsted, C H , Reisenauer A M , Shane, B and Tamura, T (1978) Avallability of monoglutamyl and polyglutamyl folates in normal subjects and in patients with coeliac sprue Gut 19, 886-891

Halsted, C H , Robles, E A, and Mezey, E (1971) Decreased jejunal uptake of labeled folıc acıd (3H-PGA) in alcoholic patients roles of alcohol and malnutrition $N$ Engl $J$ Med 285, 701706

Heınle, AW and Welch, AD (1947) Folic acid in pernicious anemia Falure to prevent neurologic relapse JAMA 133, 739-741

Herbert, $V$ and Zalusky, $R$ (1962) Interrelations of vitamın B12 and folic acıd metabolısm folic acid clearance studies J Cin Invest 41, 1263-1276 
Heseker, H and Schmitt, G (1987) Effect of long-term supplementation of folate on folate status in plasma and erythrocytes $J$ Nutr Sci Vitaminol 33, 163-168

Hibbard, ED and Smithells, RW (1965) Folic acid metabolism and human embryopathy Lancet I, 1254-1254

Homocysteıne Lowerıng Trialısts' Collaboration (1998) Lowering blood homocysteıne with folic acid based supplements meta-analysıs of randomised trials $\mathrm{Br}$ Med J 316, 894-898

Horne, DW and Patterson, D (1988) Lactobacillus casel microbıological assay of folic acid derivatives in 96-well microtiter plates Clin Chem 34, 2357-2359

Jacob, R A, Pianalto, F S, Henning, S M , Zhang, J Z, and Swendseid, ME (1995) In vivo methylation capacity is not impaired in healthy men during short-term dietary folate and methyl group restriction $J$ Nutr $125,1495-1502$

Jacob, R A, Wu, M M , Hennıng, S M , and Swendseıd, M E (1994) Homocysteine Increases as folate decreases in plasma of healthy men during short-term dietary folate and methyl group restriction $J$ Nutr 124, 1072-1080

Jacques, PF, Bostom, A G, Williams, R R, Ellıson, R C, Eckfeldt, J H, Rosenberg, IH, Selhub, J , and Rozen, $R$ (1996) Relation between folate status, a common mutation in methylenetetrahydrofolate reductase, and plasma homocysteıne concentrations Circulation 93, 7-9

Kang S -S, Zhou, J, Wong, PWK, Kowalysın, J, and Strokosch, G (1988) Intermediate homocysteınemia a thermolabile variant of methylenetetrahydrofolate reductase $A m \mathrm{~J}$ Hum Genet 43, 414-421

Kauwell, G P A , Baıley, L B , Gregory, J F , Bowlıng, D W , and Cousıns, R J (1995) Zınc status is not adversely affected by folic acid supplementation and zinc does not impair folate utilization in human subjects J Nutr 125, 66-72

Keagy, P M , Shane, B , and Oace, S M (1988) Folate bioavallability in humans effects of wheat bran and beans Am J Clin Nutr 47, 80-88

Kelly, P, McPartın, J M , Goggıns, M , Weır, D G, and Scott, J M (1997) Unmetabolized folıc acıd in serum acute studies in subjects consuming fortified food and supplements $A m J$ Clin Nutr 65, 17901795

Kirke, PN, Daly, LE, and Elwood, JH (1992) A randomized trial of low dose folic acid to prevent neural tube defects Arch Dis Child 67, 1442-1446

Koch, M C , Stegmann, K, Ziegler, A, Schroter, B, and Ermert, A (1998) Evaluation of the MTHFR C677T allele and the MTHFR gene locus in a German spina bifida population Eur J Pediatr 157, 487-492

Kownackı Brown, P A, Wang, C, Balley, L B, Toth, J P, and Gregory, J F (1993) Urınary excretion of deuterium-labeled folate and the metabolite p-amınobenzoylglutamate in humans $J$ Nutr 123, 1101-1108

Laurence, KM , James, N, Mıller, M H , Tennant, G B , and Campbell, H (1981) Double-blınd randomised controlled trial of folate treatment betore conception to prevent recurrence of neural-tube defects $\operatorname{Br} M e d J 282$, 1509-1511 
Lowe, KE, Osborne, C B , Lın, B F, Kım, J S , Hsu, J C , and Shane, B (1993) Regulatıon of folate and one-carbon metabolism in mammalian cells II Effect of folylpoly-gammaglutamate synthetase substrate specificity and level on folate metabolism and folylpolygamma-glutamate specificity of metabolic cycles of one-carbon metabolism J Biol Chem $268,21665-21673$

Malınow, M R, Duell, PB, Hess, DL, Anderson, PH, Kruger, WD, Phillipson, BE, Gluckman, RA, Block, PC, and Upson, BM (1998) Reduction of plasma homocyst(e)ıne levels by breakfast cereal fortified with folic acid in patients with coronary heart disease N Engl J Med 338 1009-1015

Margo, G, Barker, M, Fernandez-Costa, F, Colman, N, Green, R, and Metz, J (1975) Prevention of folate deficiency by food fortification VII The use of bread as a vehicle for folate supplementation Am J Cin Nutr 28, 761-763

Mason, J B (1990) Intestınal transport of monoglutamyl folates in mammalian systems in Folic acıd metabolism in health and disease, 47-64 Edited by Picciano, M F , Stokstad E.L R , and Gregory, J F , New York, Wiley-Liss

McPartlın, J M , Halıgan, A , Scott, J M , Darlıng, M D , and Weır, D G (1993) Accelerated folate breakdown in pregnancy Lancet 341, 148-149

Mills, J L, McPartiın, J M , Kırke, P N , Lee, Y J , Conley, M R , Weir, D G , and Scott, J M (1995) Homocysteine metabolism in pregnancies complicated by neural-tube defects Lancet $345,149-151$

Morrison, H I, Schaubel, D Desmeules, M, and Wigle, DT (1996) Serum folate and risk of fatal coronary heart disease JAMA 275, 1893-1896

MRC Vitamın Study Research Group (1991) Preventıon of neural tube defects Results of the Medical Research Councıl Vitamın Study Lancet 338, 131-137

Naughton, C A , Chandler, C J, Duplantıer, A B , and Halsted, C H (1989) Folate absorption in alcoholic pigs in vitro hydrolysis and transport at the intestinal brush border membrane Am J Clin Nutr 50, 1436-1441

Naurath, H J, Joosten, E Riezler, R, Stabler, SP, Allen, R H, and Lindenbaum, J (1995) Effects of vitamın B12, folate, and vitamın $B 6$ supplements in elderly people with normal serum vitamın concentrations Lancet 346, 85-89

Neuhouser, M L, Beresford, S A A, Hickok, D E , and Monsen, E R (1998) Absorption of dietary folate and supplemental folate in women with prior pregnancies with neural tube defects and controls J Am Coll Nutr 6, 625-630

O'Broın, J D, Temperley, I J, Brown, J P, and Scott, J M (1975) Nutritional stability of various naturally occurring monoglutamate derivatives of folıc acid $A m J$ Clin Nutr 28, 438-444

O'Keefe, C A Balley, L B, Thomas, E A, Hofler, S A, Davis, B A, Cerda, J J , and Gregory, J F (1995) Controlled dietary folate affects status in nonpregnant women $J$ Nutr 125, $2717-2725$

Pancharunitı, N, Lewis, C A, Sauberlich HE, Perkıns, L L, Go, R C , Alvarez, J O, Macaluso, $M$ Acton RT, Copeland, R B, Cousins, A L, Gore, T B , Cornwell, PE, Roseman, J M (1994) Plasma homocyst(e)ine, folate, and vitamin B-12 concentrations and risk for early-onset coronary artery disease Am J Clin Nutr 59, 940-948 
Perry, $\mathrm{J}$ and Chanarın, I (1970) Intestınal absorption of reduced folate compounds in man $\mathrm{Br} J$ Haematol 18, 329-339

Perry, J and Chanarın, I (1973) Formylation of folates as a step in physiological folate absorption BrMed J 2, 58-59

Pfelffer, C M , Rogers, LM , Balley, LB, and Gregory, J F (1997) Absorption of folate from fortified cereal-grain products and of supplemental folate consumed with or without food determıned by using a dual-label stable-ısotope protocol Am J Clin Nutr 66, 1388-1397

Pietrzik, $K$ and Remer, $T$ (1989) [Bıoavailability study of micronutrients] Zur Bloverfugbarkeltsprufung von Mikronahrstoffen Z Ernahrungswiss 28, 130-141

Potgieter, H, Ubbink, J B, Bissbort, S, Bester, M J , Spıes, J H, and Vermaak, W J (1997) Spontaneous oxidation of methionine effect on the quantification of plasma methionıne levels Anal Blochem 248, 86-93

Refsum, H, Ueland, PM, Nygard, O, and Vollset, SE (1998) Homocysteine and cardiovascular disease Annu Rev Med 49, 31-62

Reisenauer, A and Halsted, C H (1987) Human folate requirements J Nutr 117, 600-602

Reisenauer, A M , Buffington, C A T, Villanueva, JA, and Halsted, C H (1989) Folate absorption in alcoholic pigs in vivo intestınal pertusion studies Am J Clin Nutr 50, 14291435

Reısenauer, A M , Krumdieck, CL, and Halsted, C H (1977) Folate conjugase two seperate activities in human jejunum Science 198, 196-197

Retıef, F P (1969) Urinary folate excretion after ingestion of pteroylmonoglutamic acıd and food folate Am J Clin Nutr 22, 352355

Richardson, RE, Healy, M J, and Nixon, PF (1979) Folates of rat tissue Bioassay of tissue folylpolyglutamates and a relationship of liver folylpolyglutamates to nutritional folate sufficiency Biochim Biophys Acta 585, 128-133

Rımm, E B , Willett, W C , Hu, F B , Sampson, L, Coldıtz, G A , Manson, J E , Hennekens, C , and Stampfer, M J (1998) Folate and vitamın B6 from diet and supplements in relation to risk of coronary heart disease among women JAMA 279, 359-364

Rogers, L M , Pfeiffer, C M , Balley, L B , and Gregory, J F (1997) A dual-label stable-IsotopıC protocol is suitable for determination of folate bioavallability in humans evaluation of urinary excretion and plasma folate kınetics of intravenous and oral doses of [13C5] and [2H2]folıc acid J Nutr 127, 2321-2327

Rosenberg, IH and Godwin, HA (1971) The digestion and absorption of dietary folate Gastroenterology 60, 445-463

Rowland, M and Tozer, TN (1989) Clinical Pharmacokınetics Concepts and Applications, Philadelphia, Lea and Febıger

Rubın, E and Farber, J L (1995) Developmental and genetic diseases In Essential pathology, 125-160 Edited by Rubın, E and Farber, J L , Piladelphı, J B Lıppıncott Company 
Russell, R M, Rosenberg, I H, Wilson, P D , Iber, F L, Oaks, E B, Giovett, A C , Otradovec, $C L$, Karwoskı, P A, and Press, A W (1983) Increased urinary excretion and prolonged trunover time of folıc acid during ethanol ingestion Am J Clin Nutr 38, 64-70

Sauberlıch, HE, Kretsch, M J, Skala, J H, Johnson, HL, and Taylor, P C (1987) Folate requirement and metabolism in nonpregnant women Am J Clin Nutr 46, 1016-1028

Savage, DG and Lindenbaum, JL (1995) Folate-cobalamın Interactıons In Folate in health and disease, 237-285 Edited by Baıley, L B, New York, Marcel Dekker

Sayers, G M , Hughes, N , Scallan, E , and Johnson, Z (1997) A survey of knowledge and use of folıc acıd among women of chıld-bearıng age in Dublın J Public Health Med 19, 328-332

Schorah, C J, Devitt, H , Lucock, M , and Dowell, A C (1998) The responsiveness of plasma homocysteine to small increases in dietary folıc acid a primary care study Eur J Clin Nutr 52, 407-411

Schrijver, J, Speek, AJ, and Schreurs, WHP (1981) Semi-automated fluorimetric determınation of pyridoxal-5'-phosphate (Vitamın B6) In whole blood by high-performance liquid chromatography (HPLC) Int $J$ Vitam Nutr Res 51, 216-222

Scriver C R, Gregory, D M, Sovetts, D and Tissenbaum, G (1985) Normal plasma free amino acid values in adults the influence of some common physıological varıables Metabolism 34 868-873

Selhub, J, Brin, H, and Grossowicz, N (1973) Uptake and reduction of radioactive folate by everted sacs of rat small intestıne Eur J Bıchem 33, 433-438

Selhub, J, Dhar, G J , and Rosenberg, I H (1983) Gastrointestınal absorption of folates and antifolates Pharmacol Ther 20397418

Selhub, J , Jacques, P F , Bostom, A G, D'Agostıno, A B , Wilson, P W , Belanger, A J , O'Leary, D H , Wolf, P A , Schaefer, E J , and Rosenberg, I H (1995) Associatıon between plasma homocysteıne concentrations and extracranıal carotıd-artery stenosıs $\mathrm{N} \mathrm{Engl} \mathrm{J} \mathrm{Med} 332$, 286-291

Shane, B (1995) Folate chemistry and metabolısm In Folate in health and disease, 1-22 Edited by Balley, L B , New York, Marcel Dekker,Inc

Smıthells, R W , Seller, M J, Harrıs, R, Fieldıng, D W , Schorah, C J, Nevin, N C , Sheppard, S , Read, AP, Walker, S, and Wild, J (1983) Further experience of vitamin supplementation for prevention of neural tube defect recurrences Lancet i, 1027-1031

Stampfer, M J, Malınow, M R, Willett, W C , Newcomer, L M, Upson, B , Ullmann, D, Tishler, $P V$, and Hennekens, $C H$ (1992) A prospective study of plasma homocyst(e)ine and risk of myocardial infarction in US physicians JAMA 268, 877-881

Steegers Theunissen RPM Boers, G H J, Blom, H J, Nıłhuss, J G, Thomas, C M G, Borm, G F and Eskes, TKA B (1995) Neural tube defects and elevated homocystenne levels in amniotic fluıd Am J Obstet Gynecol 172, 1436-1441

Steegers Theunissen, R P M , Boers, G H J, Trıbels, F J , and Eskes, TKA B (1991) Neuraltube defects and derangement of homocysteine metabolism New Engl J Mod 324, 199 199 
Steegers Theunıssen, A P M , Boers, G H J , Trıbels, F J , Finkelsteın, J D , Blom, H J , Thomas, $C M$, Borm, GF, Wouters, MGAJ, and Eskes, TKAB (1994) Maternal hyperhomocysteinemia a risk factor for neural-tube defects? Metabolism 43, 1475-1480

Stıchtıng NEVO (1993) Dutch Nutrient Data Base, The Hague, Voorlıchtıngsbureau voor de Voeding

Stites, T E, Bailey, L B , Scott, K C , Toth, J P, Fisher, W P, and Gregory, J F (1997) Kinetıc modeling of folate metabolism through use of chronic admınistration of deuterium-labeled folic acid in men Am J Clin Nutr 65, 53-60

Strain, JJ and West, CE (1999) The challenge of bioavallability Proceedings of the Bioavaılability meetıng Eur J Clin Nutr (In Press)

Strum, W B (1979) Enzymatic reduction and methylation of folate following pH-dependent carrier-mediated transport in rat jejunum Blochım Bıophys Acta 554, 249-257

Tamura, $T$ (1995) Nutrient interaction of folate and zinc In Folate in health and disease, 287312 Edited by Balley, L B , New York, Marcel Dekker, Inc

Tamura, T and Stokstad, E LR (1973) The avallability of food folate in man Br J Haematol 25, 513.532

Tamura, T, Freeberg, LE, and Cornwell, PE (1990) Inhibition of EDTA of growth of Lactobacillus case in the folate microbiological assay and is reversal by added manganese or iron Clin Chem 1993,

Tamura, T, Shane, B, Baer, M T, King, J C, Margen, S, and Stokstad, E LA (1978) Absorption of mono- and polyglutamyl folates in zınc-depleted man Am J Clin Nutr 31, 1984-1987

te Poele-Pothoff, M T, van den Berg, M, Franken, D G , Boers, G H , Jakobs, C , de Kroon, I F, Eskes, TKA B. Trujbels, J M, and Blom, HJ (1995) Three different methods for the determination of total homocysteıne in plasma Ann Clin Bıochem 32, 218-220

Thorand, B, Pietrzık, K, Prınz, LR, Hages, M, and Holzgreve, W (1996) Maternal and fetal serum and red blood cell folate and vitamın B12 concentrations in pregnancies affected by neural tube defects $Z$ Geburtshilfe Neonatol 200, 176-180

Toiner, B , Roy, K, and Sirotnak, FM (1998) Structural analysıs of the human RFC-1gene encoding a folate transporter reveals multiple promotors and alternatively spliced transcripts with 5' end heterogeneity Gene 211, 331-341

Truswell, A S and Kounnavong, S (1997) Quantitative responses of serum folate to increasıng Intakes of folic acid in healthy women Eur J Clin Nutr 51, 839-845

Tucker, KL, Selhub, J , Wilson, P W , and Rosenberg, I H (1996) Dietary intake pattern reiates to plasma folate and homocysteıne concentratıons in the Framıngham Heart Study $J$ Nutr 126, 3025-3031

Ubbınk, JB (1997) The role of vitamıns in the pathogenesis and treatment of hyperhomocyst(e)ınaemia $J$ Inherit Metab Dis 20, 316-325 
Ubbınk, J B, Vermaak, W J, van der Merwe, A, and Becker, P J (1993) Vitamın B-12, vitamın B-6, and folate nutritional status in men with hyperhomocysteinemia Am J Clin Nutr 57, $47-53$

Ubbınk, J B, Vermaak, W J , van der Merwe, A, Becker, P J, Delport, A, and Potgieter, H C (1994) Vitamın requirements for the treatment of hyperhomocysteinemı in humans $J$ Nutr 124, 1927-1933

Ueland, P M , Refsum, H M , and Brattstrom, L (1993) Plasma homocysteine and cardıovascular disease In Atherosclerotic cardiovascular disease, hemostasis, and endothelial function, 183-236 Edited by Boyer Francis Jr , A , New York, Marcel Dekker, Inc

US Department of Health and Human Services Food and Drug Admınıstration (1996) Food standards amendment of the standards of identity for enriched grain products to require addition of folic acid Fed Regist 61, 8781-8807

US Public Health Service (1992) Recommendations for the use of folic acid to reduce the number of cases of spina bifida and other neural tube defects Morbid Mortal Weekly Rep 41, RR-14

van den Berg, M , Franken, D G, Boers, G H J, Blom, H J, Jakobs, C, Stehouwer, C D, and Rauwerda, J A (1994) Combıned vitamın B6 plus folic acid therapy in young patients with arterısclerosis and hyperhomocysteınemia J Vasc Surg 20, 933-940

van der Put, N M J, Eskes, T KA B , and Blom, H J (1997a) Is the common 677C-T mutation in the methylenetetrahydrafolate reductase gene a risk factor for neural tube defects? $\mathrm{A}$ meta-analysıs $Q J M 90,111-115$

van der Put, NMJ, Steegers Theunıssen, APM, Frosst, $P$, Trıbels, F J, Eskes, TKA B, Heuvel van den, LP, Marıman, E C M , den Heıjer, M, Rozen, R, and Blom, H J (1995) Mutated methylenetetrahydrofolate reductase as a risk factor for spina bifida Lancet 346 , 10701071

van der Put, NMJ, Thomas, CMG, Eskes, TKAB, Trybels, F J, Steegers Theunissen, R P M , Marıman, E C , De Graaf-Hess, A, Smeitınk, J A, and Blom, H J (1997b) Altered folate and vitamin $B 12$ metabolism in families with spina bifida offspring $Q J M$ 90, $505-510$

Varela-Moreıras, G and Selhub, J (1992) Long-term folate deficiency alters folate content and distribution differentially in rat tissues $J$ Nutr 122, 986-991

Voedingsraad (1992) Nederlandse voedingsnormen 1989, The Hague, Voorlıchtıngsbureau voor de Voeding

Wagner, C (1995) Bıochemical role of folate in cellular metabolism In Folate in health and disease, 23-42 Edited by Balley, L, New York, Marcel Dekker,Inc

Ward, G J and Nixon, P F (1990) Modulation of pteroylpolyglutamate concentration and length in response to altered folate nutrition in a comprehensive range of rat tissues $J$ Nutr 120 , 476-484

Ward, M, McNulty, H, McPartlın, J, Straın, J J, Weır, D G, and Scott, J M (1997) Plasma homocysteıne, a risk factor for cardıovascular disease, is lowered by physiological doses of folic acid QJM 90, 519-524 
Weekes, EW, Tamura, T., Davis, R.O., Birch, R., Vaughn, W.H., Franklın, J.C., Barganier, C., Cosper, P. Finley, S C., and Finley, W.H. (1992) Nutrient levels in amniotic fluid from women with normal and neural tube defect pregnancies Bıol Neonate 61, 226-231.

WeI, M M , Bailey, LB., Toth, JP. and Gregory, JF. (1996) Bıoavallability for humans of deuterium-labeled monglutamyl and polyglutamyl folates is affected by selected foods $J$ Nutr 126, 3100-3108.

Weı, M M. and Gregory, J.F. (1998) Organic acids In selected foods inhibit intestinal brush border pteroylpolyglutamate hydrolase in vitro: Potential mechanısm affectıng the bioavailability of dietary polyglutamyl folate. J Agric Food Chem 46, 211-219.

Whitehead, A S., Gallagher, P., Mills, J.L., Kirke, P.N., Burke, H., Molloy, A.M., Weir, D.G., Shields, D C , and Scott, J M. (1995) A genetic defect in 5,10-methylenetetrahydrofolate reductase in neural tube defects. QJM 88, 763-766.

Yates, A A , Schlıcker, S.A., and Sultor, C.W. (1998) Dietary reference intakes: the new basis for recommendation for calcium and related nutrients, B vitamıns and cholıne. J Am Diet Assoc 98, 699-706

Zettner, A., Boss, G R, and Seegmiller, J.E. (1981) A long-term study of the absorption of large oral doses of folıc acıd Ann Clin Lab Scı 11, 516-524. 


\section{Summary}

An elevated total plasma homocysteine concentration is a risk factor for women for neural tube defects and for men and women for cardiovascular disease. The intervention studies described in this thesis focused on the effects of synthetic folic acid and natural dietary folate on plasma total homocysteine concentrations and folate status.

In the first study (Chapters 2 and 3) we investigated whether low doses of folic acid every other day could decrease plasma total homocysteine concentrations and improve the folate status in healthy volunteers. In a randomised study with 144 healthy women, we provided subjects with either $500 \mu \mathrm{g}$ of folic acid every day, or $500 \mathrm{\mu g}$ of folic acid every other day, or a placebo tablet daily for four weeks. Both folic acid intervention strategies significantly improved plasma folate and red blood cell folate concentrations. Intervention with $500 \mu \mathrm{g}$ of folic acid each day decreased plasma total homocysteine concentrations by $22 \%$ and intervention with $500 \mu \mathrm{g}$ of folic acid every other day decreased the concentrations by $11 \%$. The study showed that the washout period after four weeks of intervention with folic acid is more than 8 weeks.

Folic acid supplementation is most likely to affect the remethylation reaction from methionine into homocysteine. Therefore, supplementation with folic acid can be expected to not only decrease plasma total homocysteine concentrations, but also to increase plasma methionine concentrations. However, four weeks of intervention with low doses of folic acid $(500 \mu \mathrm{g} / \mathrm{d}$ or $500 \mu \mathrm{g} / 2 \mathrm{~d})$ did not influence fasting plasma methionine concentrations in healthy volunteers (Chapter 3).

In Chapter 2 subjects in one group took tablets containing $500 \mu \mathrm{g}$ of folic acid every other day and placebo tablets on alternate days. Therefore, the second study (Chapter 4) examined whether supplementation with $500 \mu \mathrm{g}$ of folic acid every other day has a similar homocysteine lowering capacity as supplementation with $250 \mu \mathrm{g}$ of folic acid each day. Although the difference in change in homocysteine between the groups $(0.64 \mu \mathrm{mol} / \mathrm{L})$ was not significant, the results of the study suggested that the 250- $\mu \mathrm{g}$ dose each day had more homocysteine lowering capacity than the 500- $\mu \mathrm{g}$ dose every other day. This suggests that not all folic acid of the higher dose can be metabolised to the 5-methyltetrahydrofolate form that serves a methyl donor for the remethylation of homocysteine to methionine.

The third study (Chapter 5) firstly addressed the question whether spina bifida patients have an impaired folate and homocysteine status. Secondly, the study investigated how effective supplementation with $500 \mu \mathrm{g}$ of folic acid for four weeks 
Summary

decreased homocysteıne concentrations and improved the folate status in spına bifida and disabled control patıents No ındicatıons for an impaired homocysteıne or folate metabolism in patients with a spina bifida were shown In additıon, folic acid supplementation seemed at least as effective in spina bifida patients as in control patıents Therefore, other factors, such as a higher need for folıc acid by the mother, or a defect in the intrauterine transport from mother to child are probably more important causes for neural tube defects than a defect in the child itself

In the fourth study (Chapter 6) we Investıgated whether a high daily dose of folate from vegetables and citrus fruit decreases plasma total homocysteine concentrations and improves the folate status In a dietary controlled intervention study subjects received either a diet with a normal folate content (on average 210 $\mu \mathrm{g} / \mathrm{d}$ ) and a placebo tablet, or the same diet in combination with every other day a $500 \mu \mathrm{g}$ folic acid tablet, or a diet high in dietary folate from vegetables and citrus fruit $(560 \mu \mathrm{g} / \mathrm{d})$ and a placebo tablet The intervention with the dietary folate from vegetables and citrus fruit decreased plasma total homocysteine concentrations and improved the folate status The bioefficacy of the dietary folate from vegetables and citrus fruit compared to folic acid was $60 \%$ in this study The bioavailability was $78 \%$ when change in plasma folate was used as the determınant of bıavailability and $98 \%$ when change in red blood cell folate was used The fact that intervention with folic acid was accomplished by supplying the tablets every other day may have overestımated the effect of the dietary folate compared to the folıc acıd However, the study clearly showed that dietary folate from vegetables and citrus fruit decreased plasma total homocysteıne concentrations and increased the folate status in healthy volunteers

Chapter 7 reviewed the literature with respect to factors influencing bıoavailability of folate and folıc acid Two factors stand out in effect food matrix and amount of folic acid ingested The studies in the review also suggest that glutamate chain length plays a role as well

In conclusion, daily doses as low as $250 \mu \mathrm{g}$ of folic acid in addition to the habitual diet of healthy volunteers decrease plasma total homocysteıne concentrations and improve the folate status An impaired folate or homocysteıne metabolısm in patients with a spına bifida seems not an important risk factor for the occurrence of the spına bifida Supplementation with $500 \mu \mathrm{g}$ of folic acid each day seems comparable effective in spina bifida patients as in control subjects Finally, not only synthetic folic acid, but also a high intake of dietary folate from vegetables and citrus fruit decreases plasma total homocysteıne concentrations and improves the folate status in healthy volunteers 


\section{Samenvatting}

Foliumzuur is een B-vitamine dat van belang is voor de gezondheid van de mens Dit proefschrift beschrift enkele aspecten van het foliumzuurmetabolisme Onderzoek naar foliumzuur is belangrık, omdat er verband lıkt te zınn met aangeboren neuralebuisafwıjkıngen (bıjv een spına bifida = open ruggetje) en met hart- en vaatzıekten $W_{1 j}$ hebben met name de invloed van het innemen van extra follumzuur op het homocysteınegehalte en de bılogısche beschıkbaarheid van folaat uit voedsel bestudeerd We spreken van foliumzuur als het om de synthetische vorm gaat en van folaten als het om de natuurlıjke vormen van dit vitamıne gaat De folaatstatus bij de mens wordt bepaald door meting van folaten in rode bloedcellen en in het bloedplasma Homocysteıne ontstaat als het aminozuur methıonıne in ons lichaam afgebroken wordt Amınozuren zı!n bouwstenen van eiwitten Methionine is een amınozuur dat het lichaam niet in voldoende mate kan aanmaken en dat daarom met de voeding moet worden ingenomen De omzettıng van methıonine naar homocysteıne wordt beınvloed door foliumzuur Inname van hoge doses foliumzuur in aanvulling op de gebrukelıjke voeding kan het homocysteınegehalte verlagen

Uit eerdere onderzoeken is gebleken dat het innemen van extra follumzuur in de perıode rond de bevruchting de kans op het krıgen van een kindje met een neurale-buısafwıkıng aanzienlık verkleint Bovendien hebben vrouwen die eerder een kındje met een neurale-buisafwikıng hebben gehad gemiddeld een hoger homocysteınegehalte in het bloedplasma dan vrouwen die een gezond kınd hebben gehad Niet alleen vrouwen die eerder een kınd met een neurale-buisafwijkıng hebben gehad, maar ook mensen die aan hart- en vaatzıekten lıden hebben vaker een verhoogd homocysteınegehalte dan gezonde mensen

Bif de start van ons onderzoek was reeds bekend dat het mogelık is het homocysteınegehalte te verlagen door inname van folumzuur in doses boven de $650 \mu \mathrm{g}$ per dag in aanvulling op de normale voeding Over het effect van Inname van lagere doses folıumzuur op de folaatstatus en homocysteinegehaltes in het bloed was minder bekend Ook was nog onduidelık of het mogelık is om met extra natuurlık folaat uit de voeding de folaat- en homocysteınegehaltes gunstig te beınvloeden Voorts was nog niet duidelık op welke wıze extra foltumzuur de kans op het krıgen van een kınd met een neurale-buısafwıkıng verkleınt Het onderzoek dat beschreven is in dit proefschrift ging daarom uit van de volgende vragen

- Is het mogelijk om bij gezonde vrıwilligers de folaatstatus te verbeteren en het homocysteınegehalte te verlagen door het verstrekken van folıumzuur in doses tussen de 250 en $500 \mu \mathrm{g}$ per dag in aanvullıng op de gebrulkelıke voedıng? 
- Is bI patienten met een open rug de folaat- en homocysteinestofwisseling afwıkend ten opzichte van controlepatıenten? Wat is by patıenten met een open rug het effect van het verstrekken van extra folıumzuur op de folaat- en homocysteinestatus?

- Is het bij gezonde vrıwillıgers mogelık om met natuurlıje folaten uit groenten en fruit de folaatstatus te verbeteren en het homocysteınegehalte te verlagen en hoe verhoudt dit effect zich tot het effect van synthetısch folıumzuur?

Om de eerste vraag te beantwoorden werd een studie uitgevoerd waaraan 144 gezonde jonge vrouwen deelnamen (hoofdstuk 2) Deze vrouwen werden ingedeeld in drie groepen en slikten gedurende vier weken, of $500 \mu \mathrm{g}$ folıumzuur per dag, of $500 \mu \mathrm{g}$ folıumzuur om de dag, of een placebotabletje ledere dag Daarnaast consumeerden de vrouwen hun normale dagelıkse voeding, die gemiddeld $280 \mu \mathrm{g}$ folaat per dag bevatte De placebotabletjes bevatten slechts vulmiddel en geen vitamıne, maar waren niet te onderscheiden van de folıumzuurtabletjes In de beide groepen die folıumzuur ontvingen stegen de folaatgehaltes in bloedplasma en in rode bloedcellen en daalden de homocysteınegehaltes in het plasma De interventie met folıumzuur had geen effect op de gehaltes aan het amınozuur methıonıne in het bloedplasma (hoofdstuk 3) Acht weken nadat de interventıeperiode was afgelopen werden de gehaltes nogmaals gemeten De folaatgehaltes in de groepen die folıumzuur hadden gekregen waren nog steeds verhoogd ten opzichte van de placebogroep en de homocysternegehaltes waren ook nog steeds verlaagd Dit betekent dat het gunstige effect van extra folıumzuur nog tenmınste enkele weken door blıft werken

In deze eerste studie hebben we aan een van de groepen om de dag een tabletje met $500 \mu \mathrm{g}$ folıumzuur verstrekt We hebben daarom in een volgende studie onderzocht of het effect van $500 \mu \mathrm{g}$ foliumzuur om de dag vergelıkbaar is met het effect van $250 \mu \mathrm{g}$ foliumzuur ledere dag (hoofdstuk 4) De dosis van $250 \mathrm{\mu g}$ folıumzuur per dag leek effectıever het homocysteinegehalte in het bloedplasma te verlagen dan de dosis van $500 \mu \mathrm{g}$ foliumzuur om de dag Dit suggereert dat bij een dosis van $500 \mu \mathrm{g}$ niet al het folıumzuur beschıkbaar is voor de verlaging van het homocysteınegehalte

In de derde studie hebben we allereerst onderzocht of patıenten met een spına bıfıda een afwıkend folaat- en homocysteınemetabolısme hebben in vergelıkıng met controlepatıenten (hoofdstuk 5) Vervolgens hebben we gedurende vier weken onderzocht hoe goed $500 \mu \mathrm{g}$ foliumzuur per dag de folaatgehaltes verbetert en de homocysteınegehaltes verlaagt in spına bifıda patienten en by 
controlepersonen met een handicap De resultaten gaven geen aanwijzingen dat het folaat- of homocysteınemetabolısme by patıenten met een spına bifıda afwıkend zou zıjn ten opzıchte van controlepatienten Bovendien bleek de inname van $500 \mu \mathrm{g}$ folıumzuur per dag by spına bifıda patıenten minstens zo effectıef de folaatstatus te verbeteren en de homocysteınegehaltes te verlagen als blj gehandicapte controlepersonen Een afwıkıng in het folaat- en homocysteınemetabolısme van het kınd zelf lıkt dus op grond van dit onderzoek dus geen belangrıke risıcofactor voor het ontstaan van een neurale-buisafwıkıng Echter, van bepaalde genetische afwıkıngen in het folaatmetabolısme bij het kınd is wel bekend dat ze een groter risıco geven op een neurale-buisafwıkıng Andere oorzaken, zoals een hogere behoefte aan folaat van de moeder, of een afwıkıng in het transport van folaat van moeder naar kınd, zouden belangrıkere redenen kunnen zıjn waarom extra folıumzuur de kans op het krıgen van een kınd met een neurale-buısafwıkıng verkleınt

Onze eerste studies hebben aangetoond dat het mogelık is om de folaatstatus te verbeteren en het homocysteınegehalte te verlagen door inname van doses synthetısch foliumzuur van slechts $250 \mu \mathrm{g}$ per dag Dit bood perspectief voor een interventıe met natuurlıke folaten uit de voedıng Immers, indien het mogelık is om met lage doses foliumzuur in aanvulling op de normale voeding de folaatstatus te verbeteren en homocysteınegehaltes te verlagen, dan is het misschien ook haalbaar om dit effect te bereiken door de inname van extra voedingsfolaat In de vierde studie (hoofdstuk 6) hebben we dan ook onderzocht of een hoge dagelıkse dosis folaat, afkomstıg uit groenten en citrusvruchten, de folaatstatus kan verbeteren en de homocysteınegehaltes kan verlagen We hebben hıervoor gebrulk gemaakt van een zogenaamde gecontroleerde voedıngsproef in deze gecontroleerde voedıngsproef kregen de proefpersonen dagelıks 90 procent van hun dagelıkse inname aan energie van hun voeding verstrekt $Z_{\text {Ij }}$ aten op doordeweekse dagen tussen de mıddag een warme maaltıjd op de afdelıng Humane Voedıng en Epıdemıologie in Wagenıngen en kregen de overıge voedingsmiddelen (ook voor het weekend) mee naar huls Alle voedıngsmiddelen werden afgewogen Bovendien werden gedurende de proef monsters van de voeding genomen om precies te meten hoeveel folaat de voeding bevatte De deelnemers kregen, of een voeding met een normaal folaatgehalte (gemıddeld $210 \mu \mathrm{g}$ folaat per dag) en een placebotabletje, of een voeding met hetzelfde folaatgehalte en om de dag $500 \mu \mathrm{g}$ folıumzuur uit een tabletje, of een voeding die van nature rıjk is aan folaat afkomstig van groente en citrusvruchten $(560 \mu \mathrm{g}$ folaat per dag) en een placebotablet De voeding met de folaatrıke groenten en citrusvruchten verbeterde de folaatstatus en verlaagde de 
homocysteïnegehaltes van deze gezonde vrijwilligers. Het homocysteïne-verlagende effect van het folaat uit groenten en fruit was $60 \%$ ten opzichte van het synthetische foliumzuur. Het relatieve effect op het folaatgehalte in plasma was $78 \%$ en op het folaatgehalte in rode bloedcellen was $98 \%$. Deze studie toont dus duidelijk aan dat voedingsfolaat afkomstig van groenten en citrusvruchten de folaatstatus verbetert en homocysteïnegehaltes verlaagt.

Hoofdstuk 7 geeft tenslotte een overzicht van de literatuur met betrekking tot de factoren die het effect van folaat en foliumzuur op de folaatstatus (biobeschikbaarheid) en homocysteïnegehaites (biologische effectiviteit) kunnen beïnvloeden. De matrix van het voedsel en de hoeveelheid foliumzuur die wordt ingenomen lijken de belangrijkste factoren die de biologische beschikbaarheid van folaat en foliumzuur kunnen beïnvloeden.

We kunnen concluderen dat een afwijkend folaat- en homocysteinemetabolisme bij patiënten met een spina bifida geen belangrijke oorzaak lijkt te zijn voor het ontstaan van de spina bifida. Bovendien leidde interventie met $500 \mu \mathrm{g}$ foliumzuur per dag bij spina bifida patiënten tot een vergelijkbare verbetering van de folaatstatus en verlaging van homocysteïnegehaltes als bij gehandicapte controlepersonen. Derhalve geeft dit onderzoek geen aanleiding om patiënten met een spina bifida van een speciaal advies te voorzien.

Zowel een dagelijkse dosis van slechts $250 \mu \mathrm{g}$ synthetisch foliumzuur per dag in aanvulling op de gebruikelijke voeding van gezonde vrijwilligers als een hoge inname van voedingsfolaat afkomstig van groenten en fruit verbeterde de folaatstatus en verlaagde de homocysteïnegehaltes. Verlaging van homocysteïnegehaltes leidt mogelijk tot een kleinere kans op het krijgen van een kindje met een neurale-buisafwijking en tot een kleinere kans op het krijgen van hart- en vaatziekten. Dit geeft een extra ondersteuning voor het advies van het Voorlichtingsbureau voor de Voeding om dagelijks tenminste 200 gram groenten en 2 stuks fruit te eten. Echter, vrouwen die van plan zijn zwanger te worden moeten daarnaast nog steeds iedere dag 400 tot $500 \mu \mathrm{g}$ synthetisch foliumzuur tot zich nemen. Dit, omdat extra voedingsfolaat mogelijk het risico op het krijgen van een neurale-buisafwijking verkleint, maar uit eerdere onderzoeken is gebleken dat extra foliumzuur dit zeker doet. 


\section{Dankwoord}

Het proefschrift is af! Het staat op mijn naam, maar gelukkig heb ik niet alles alleen hoeven doen. Heel veel mensen hebben mij op verschillende manieren bijgestaan. Ik wil iedereen die op welke manier dan ook een bijdrage heeft geleverd bedanken, maar een aantal mensen wil ik graag in het bijzonder noemen.

Allereerst alle mensen die als deelnemer aan de verschillende proeven hebben meegewerkt. Zonder deelnemers geen "Human intervention studies", daarom wil ik hen allen van harte bedanken voor hun tijd en moeite.

Prof. TKAB Eskes en prot. JGAJ Hautvast, mijn promotoren. Professor Eskes, u zette het proces in gang. Reeds in 1993 nodigde u mij uit om eens te komen praten en omdat $u$ het wel zag zitten met deze "ingenieur" is het onderzoek uiteindelijk van start gegaan. Hartelijk dank dat $u$ de motor achter dit onderzoek wilde zijn. Professor Hautvast, steeds weer wist u mij op een positieve manier te stimuleren. Bovendien gaf u mij vertrouwen en heb ik veel geleerd van uw 'tactische' aanwijzingen.

Régine Steegers-Theunissen en Marijke van Dusseldorp, als co-promotoren waren jullie beide nauw betrokken bij het onderzoek. Régine, vanaf het eerste begin zijn we er tegen aan gegaan en jij hebt mij altijd gesteund, ook toen de geldschieter voor het eerste voorstel zich op het laatste moment terugtrok. In zes weken tijd hebben we toen een ruw concept voor een samenwerkingsproject met Wageningen uitgewerkt tot een volledig promotieonderzoek. Die moeite werd gelukkig gehonoreerd door het Praeventiefonds. Het eindresultaat ligt hier nu en ik wil je bedanken voor de niet geringe bijdrage daaraan. Marijke, ook jij hebt meer dan 'je steentje' bijgedragen aan dit onderzoek. Vele uren hebben we samen zitten brainstormen en puzzelen om de proeven zo optimaal mogelijk te laten verlopen. Van jouw gedegen en structurele aanpak heb ik veel geleerd. Bedankt!

Clive West, geen supervisor, maar wel een super adviser. Ik ben blij dat je ondanks je drukke werkzaamheden altijd bereid was mij van advies te voorzien.

Bij de praktische uitvoering van de proeven heb ik van heel veel mensen hulp gehad. Ik wil graag de studenten, Caroelien Schuurman, Marieke Louwman, Nienke Loose, Maarit Laurinen, Dorien Boonstra, Nina de Bock en Marije Jimmink bedanken voor het vele praktisch werk dat ze voor hun rekening namen in het kader van een stage of afstudeervak. 
Dankwoord

Ook de dietistes en andere mensen die meewerkten aan de gecontroleerde voedıngsproef leverden een grote bıjdrage Bıjna 80 mensen van een volledige voedıng voorzıen is voorwaar geen kleıne klusı Saskıa Meıjboom, Els Sıebelınk, Jeannette Dijkstra, Caroelıen Schuurman, Mırjam Stam, Nına de Bock en Dorıen Boonstra, jullie waren geweldıg'

Michael Gaytant en Rob van Dam, fijn dat jullie steeds weer voor dag en dauw opstonden om bloed te gaan prikken op Werkenrode en in het Dorp Irıs van Roolj en Nelleke Hamel, bedankt voor de samenwerkıng tıjdens de laatste proef.

B!j alle proeven heb ik zeer veel ondersteuning gehad van laboratorımmedewerkers van verschıllende Instellıngen Graag bedank ik de medewerkers van de laboratorıa van de afdeling Humane Voedıng en Epıdemıologıe in Wagenıngen, de afdelıng Metabole Ziekten van het Wilhelmına Kınderzıekenhuis in Utrecht, de afdelıng Chemısche Endocrınologıe, de afdelıng Kındergeneeskunde en Neurologıe en het Centraal Klınısch Chemisch Laboratorium in Nımegen Ook wil ik graag de artsen en verpleegkundigen van Werkenrode en het Dorp van harte bedanken voor hun bıjdrage

Chris Robertson and Rob Urgert, great that you were willing to proof read the entıre thesis Ries Duran en Chris Thomas, bedankt voor het waardevolle commentaar bi] een aantal artıkelen

Daarnaast zın er heel veel mensen geweest die er voor gezorgd hebben dat ik op een plezıerıge manıer mın promotıewerk heb kunnen verrıchten

Mıjn collega's in Nıjmegen, Cathelıne, Erık, Jesper, Marcel, Maarten, Jan, Willanne, Els, Irıs, Mark, Nelleke, Ron, Wai Yee, Michael, Petra en Rolf wil ik bedanken voor de gezellıgheıd tıjdens mın 'Nıjmeegse dagen'. Gerda Theunıssen wıl ık bedanken voor alle 'regeldıngetjes' die ze voor mı gedaan heeft

Mın collega's in Wagenıngen wil ık zeker ook niet vergeten Nynke, Nicole, Liesbeth, Baukje, Margreet, Martıne, Marıe-Louıse, Maud, Tıny, Rıanne, Jacquelıne, Edıne, Frouwkje, en alle anderen Sorry, voor de uurtjes die ik jullie van je werk heb gehouden' Ach ja, niet alleen lol in je werk, maar ook lol op je werk is belangrık' Gezellıge AlO's, dus ook veel gezellıge lunches en te gekke trips naar Amerika, Scandınavie en Schotland Bedankt en veel succes in de toekomst 1

Mujn kamergenoten, met name Nynke de Jong en Nicole de Roos, hebben het meest 'geleden' onder mıjn aanwezıgheıd Ik heb veel geluk gehad dat ik zulke lieve en zorgzame kamergenoten heb getroffen'l Nicole, een kamergenoot die zelfs voor een warme maaltıd zorgt als $ı k$ lang door 'moet' werken zal $k$ wel nooıt meer treffen' Ook 
bedankt dat je elke keer weer bereid was om mij van computertips te voorzien. Nynke, ik vind het heel fijn dat jij mijn paranimf wilt zijn. We hebben samen heel wat 'lief en leed' gedeeld op de tweede verdieping van het Biotechnion. "Doe de deur maar even dicht" en "dat heb jij dan weer..." blijven gevleugelde uitspraken. Mochten we in de toekomst ooit nog eens samen ergens terecht komen, dan delen we gewoon weer een kamer.

Ontspanning naast het werk is ook belangrijk! lk wil alle spelers van de club met de beste secundaire voorwaarden van Nederland, het Puikje van Bennekom, bedanken voor de gezellige volleybalavonden en andere uitjes.

Holiday is also an important part of life. I would like to thank all participants of Gibson's Tours who were so kind to share their holiday time with me: Rosalind, lan, Debbie, Michael, Colin, Laura, Kevin, Alice, John, Anne, Bruce, Nancy: Thanks! Special thanks to Rosalind and lan Gibson. Dear Ros and lan, I want to thank you for organising the tours, but even more for your support and friendship.

Familie, vrienden en kennissen, fijn dat jullie steeds interesse hebben getoond! Sybren, Anna, Elsbeth en Wim, bedankt voor jullie belangstelling. Lieve Els, vanaf het begin had je er groot vertrouwen in dat jouw zus dit klusje wel even zou klaren. Ik ben blij dat jij mij als paranumf wil bijstaan bij de promotie.

Tenslotte mijn ouders, lieve pap en mam aan jullie heb ik dit proefschrift opgedragen. En terecht, want zonder jullie niet aflatende steun was ik nooit zover gekomen!

Nogmaals, iedereen bedankt!

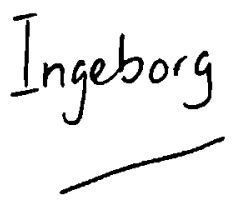





\section{Curriculum Vitae}

Ingeborg Annemarle Brouwer was born on October 4, 1968, in Apeldoorn, the Netherlands In 1987, she passed secondary school, gymnasıum B, at the 'Christelık Lyceum' in Apeldoorn In the same year she started the study 'Human Nutrition' at the Wageningen Agricultural University As part of that study she conducted research projects in Anımal Nutrition (Department of Anımal Sciences, State University Utrecht, Apr - Dec 1991), Toxicology (Department of Toxicology, Wagenıngen Agricultural University, Jan - Aug 1992) and Human Nutrition (Department of Applied Human Nutrition, University of Guelph, Canada, Sep 1992 - Mar 1993) In 1993 she received the MSc degree In 1994 she worked as a research assistant on the project 'Vitamins, homocysteine and thrombosis' at the Department of Haematology, Leyenburg Hospital, The Hague In March 1995 she started as a PhD-fellow in a collaborative project of the Department of Obstetrics and Gynaecology of the University Hospital Nımegen St Radboud and the Division of Human Nutrition and Epıdemıology of the Wagenıngen Agricultural University. She joined the education programme of the Graduate School VLAG (advanced courses in Food Technology, Agrobiotechnology, Nutrition and Health Sciences). She was the secretary of the PhD-councll of this Graduate School from 1995 through 1998 She was a member of the PhD-excursion committee that organised a study tour to Scandinavia in 1997. She participated in international courses on 'Nutritional and Ifestyle epıdemıology (1995)' and 'Ecophysiology of the gastrointestinal tract (1996)' In June 1997 she attended the Annual New England Epidemıology Summer Program at Tutts University, Boston, USA She was selected to participate in the fifth European Nutrition Leadership Programme, March 1998, Luxembourg

Since April 1999 she works as a research associate at the Wagenıngen Centre for Food Sciences 


\section{Publications}

\section{Research papers:}

Beynen AC, Brouwer IA, Lemmens AG Dietary folate vs glucose does not influence iron status in the rat Bıologıcal Trace Element Research 1992, $3589-92$

Brouwer IA, Lemmens AG, Beynen AC Dietary fructose versus glucose lowers ferrous iron absorption in rats British Journal of Nutrition 1993, 70 171-8

den Heıjer M, Bos GMJ, Brouwer IA, Gerrits WBJ, Blom HJ Variability of the methıonıne loadıng test no effect of a low proteın diet Annals of Clınıcal Bıochemıstry 1996, 33 551-4

den Heijer M, Brouwer IA, Bos GMJ, Blom HJ, Spaans AP, Rosendaal FR, Thomas CMG, Haak HL, Wijermans PW, Gerrits WBJ Vitamın supplementation reduces blood homocysteine levels a controlled trial in patients with venous thrombosis and healthy volunteers Arterıosclerosis Thrombosis and Vascular Bıology 1998, 18 356-61

Homocysteıne Lowerıng Trialısts' Collaboratıon Lowerıng blood homocysteıne with folıc acid based supplements meta-analysıs of randomised trials Britısh Medical Journal 1998, 316 894-8

Brouwer IA, van Dusseldorp M, Thomas CMG, Duran M, Hautvast JGAJ, Eskes TKAB, Steegers-Theunissen RPM Low-dose folic acid supplementation decreases plasma homocysteine a randomized trial Amerıcan Journal of Clınıcal Nutrition 1999, 69 99-104

Brouwer IA, van Dusseldorp M, West CE, Meyboom S, Thomas CMG, Duran M, van het Hof KH, Eskes TKAB, Hautvast JGAJ, Steegers-Theunissen RPM Dietary folate from vegetables and citrus fruit decreases plasma homocysteıne concentrations in humans in a dietary controlled trial Journal of Nutrition 1999 (In Press)

van het Hof $K H$, Brouwer IA, West CE, Haddeman E, Steegers-Theunissen RPM, van Dusseldorp M, Westrate JA, Eskes TKAB, Hautvast JGAJ Bloavallability of luteın from vegetables is five tımes higher than that of $\beta$-carotene American Journal of Clınical Nutrition 1999 (In Press)

Brouwer IA, van Dusseldorp M, Duran M, Thomas CMG, Hautvast JGAJ, Eskes TKAB, Steegers-Theunissen RPM Low-dose folic acid supplementation does not influence plasma methıonıne concentrations in young, non-pregnant women British Journal of Nutrition 1999 (In Press) 
Castenmiller JM, van der Poll CJ, West CE, Brouwer IA, Thomas CMG, Van Dusseldorp M The bioavallability of folate from processed spınach A controlled dietary intervention study Submitted

Brouwer IA, van Rool IALM, van Dusseldorp M, Thomas CMG, Blom HJ, Hautvast JGAJ, Eskes TKAB, Steegers-Theunissen RPM Homocysteıne lowering effect of $500 \mu \mathrm{g}$ of folic acid every other day versus $250 \mu \mathrm{g}$ per day Submitted

Brouwer IA, van Dusseldorp M, Thomas CMG, van der Put NMJ, Gaytant MA, Eskes TKAB, Hautvast JGAJ, Steegers-Theunıssen RPM Homocysteine metabolısm and effects of folıc acid supplementation in patients affected with spina bifida Submitted

\section{Other publıcations:}

Lans MC, Brouwer I, De Winden $P$, Brouwer A Different effects of $2,3,7,8$ tetrachlorodibenzo-p-dioxin and Aroclor 1254 on thryroxine metabolism and transport Organohologen Compounds, 1993, Vol 13 Human Exposure, Toxicology, Epıdemıology, 137-141

Brouwer IA, Louwman M, Schuurman C, Loose N, Duran M, van Dusseldorp $M$, SteegersTheunissen RPM Foliumzuur en homocysteıne effect van foliumzuursuppletie in lage doses op homocysteıne Voedıng 1997, 5833

de Bree $A$, van Dusseldorp $M$, Brouwer IA, van het Hof $K H$, Steegers-Theunissen RPM Folate intake in Europe recommended, actual and desired intake (review) European Journal of Clinical Nutrition 1997, 51 643-660

Brouwer IA. Meer foliumzuur voor wie, hoe en hoeveel? NWL-Workshop Foliumzuur en hart en vaatziekten Voeding 1998, 59 11-14

Brouwer IA, van Dusseldorp M, de Vries JHM, Steegers-Theunissen RPM Aanbevolen dagelıkse hoeveelheid follumzuur onvoldoende voor optımale homocysteınespiegels (letter) Nederlandse Tijdschrift voor Geneeskunde 1998, 1421473

Brouwer IA, van Dusseldorp M, West CE, Gregory III JF, Steegers-Theunissen RPM Bioavalability and efficacy of folate and folıc acid Review of the literature In preparation

\footnotetext{
Abstracts:

den Heıjer M, Brouwer IA, Blom HJ, Gerrıts WBJ, Bos GMJ Lowerıng of homocysteıne blood levels by means of vitamın supplementation Irish Journal of Medical Science 1995, 164 (suppl 15) 7
} 
Brouwer IA, Steegers-Theunissen RPM, van Dusseldorp $M$, Thomas CMG, Duran $M$, Hautvast JGAJ, Eskes TKAB Dalıng homocysteınegehalte en verbeterıng folaatstatus door suppletıe met lage dosıs folıumzuur Tıjdschrift voor Sociale Gezondheidszorg 1997, 7515

Brouwer IA Efficacy of natural dietary folate, derived from vegetables and citrus fruits, in Improving the folate and homocysteıne status Report of the fifth seminar of the European Nutrition Leadershıp Programma 1998, 56

Brouwer IA, van Dusseldorp M, West CE, Meyboom S, Thomas CMG, Duran M, van het Hof $\mathrm{KH}$, Eskes TKAB, Hautvast JGAJ, Steegers-Theunissen RPM High daily intake of dietary folate decreases homocysteıne and improves folate status a controlled dietary trial in young healthy volunteers Netherlands Journal of Medıcıne 1998, 52 S41

Den Hejer M van der Put N, Segers MFG, Brouwer IA, Blom HJ, Thomas CMG Mutated methylenetetrahydrofolate reductase and the distribution of folate metabolites Netherlands Journal of Medicine 1998, 52 S48

Meyboom S, de Vries JHM, Brouwer IA, van Staveren WA, van Dusseldorp M Folate contents of diets calculated by use of food tables compared with thos determined by a mıcrobıologıcal assay Eur J Clın Nutr 1998, 52 (supplement 2) S87

Siebelınk E, Roosemalen K, de Vries JHM, Alles M, Brouwer IA, Castenmiller JJM, van Staveren WA Self-reported energy intake by a food frequency questionnnaire compared with energy need to maintain body weight in 170 non-obese adults European Journal of Clınical Nutrition 1998, 52 S21

Brouwer IA, van Dusseldorp M West CE, Meyboom S, Thomas CMG, Duran M, SteegersTheunissen RPM Folaat uit groenten en fruit verlaagt het plasmahomocysteinegehalte Tıdschrift voor Socıale Gezondheıdszorg 1998, 7653 


\section{Stellingen}

1. Het gegeven dat een dagelijkse inname van een geringe dosis synthetisch foliumzuur het homocysteïnegehalte bij gezonde mensen kan verlagen kan er op duiden dat hun folaatstatus nog niet optimaal is (dit proefschrift).

2. Een verhoogde gemiddelde consumptie van groenten en citrusvruchten door de algehele bevolking zal leiden tot een lager gemiddeld homocysteïnegehalte en een verbeterde folaatstatus (dit proefschrift).

3. De uitgangswaarde van homocysteïne in plasma bepaalt of inname van extra foliumzuur dit niveau kan verlagen (dit proefschrift).

4. Bij gezonde mensen is het zinloos om ter verlaging van het homocysteïnegehalte foliumzuurdoses boven de $500 \mu \mathrm{g}$ per dag te geven (zie Homocysteine Lowering Trialists' Collaboration BMJ 1998; 316: 894-8; Kelly et al. Am J Clin Nutr 1997; 65 : 1790-5).

5. Verrijking van voedingsmiddelen verarmt de wetenschap.

6. Op verpakkingen van alle anti-conceptiemiddelen dient een duidelijk advies te komen voor vrouwen met zwangerschapswens om dagelijks extra foliumzuur in te nemen ter preventie van aangeboren afwijkingen.

7. De opsporing van jonge kinderen met coeliakie moet sterk verbeteren aangezien op dit moment van slechts één op de vijttien kinderen met coeliakie bekend is dat ze deze aandoening hebben (zie Csizmadia et al. Lancet 1999; 353: 813-4).

8. Uit het feit dat artsen hun werkkleding tijdens de lunchpauze aanhouden blijkt dat de 'doktersjas' nog steeds meer als statussymbool dan uit hygiënische overwegingen wordt gedragen.

9. Dankzij de Europese Gemeenschap worden verre vrienden goede buren.

10. Het ralley-point systeem bij het volleybal heeft een negatieve invloed op zowel het speel-als kijkgenot.

Stellingen behorend by het proefschrift:

'Folic acıd, folate and homocysteine. Human intervention studies'

Ingeborg Brouwer, Nymegen, 1 jull 1999. 

(9)

+<smiles>CCC</smiles>

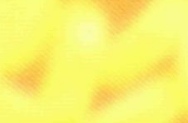

ra

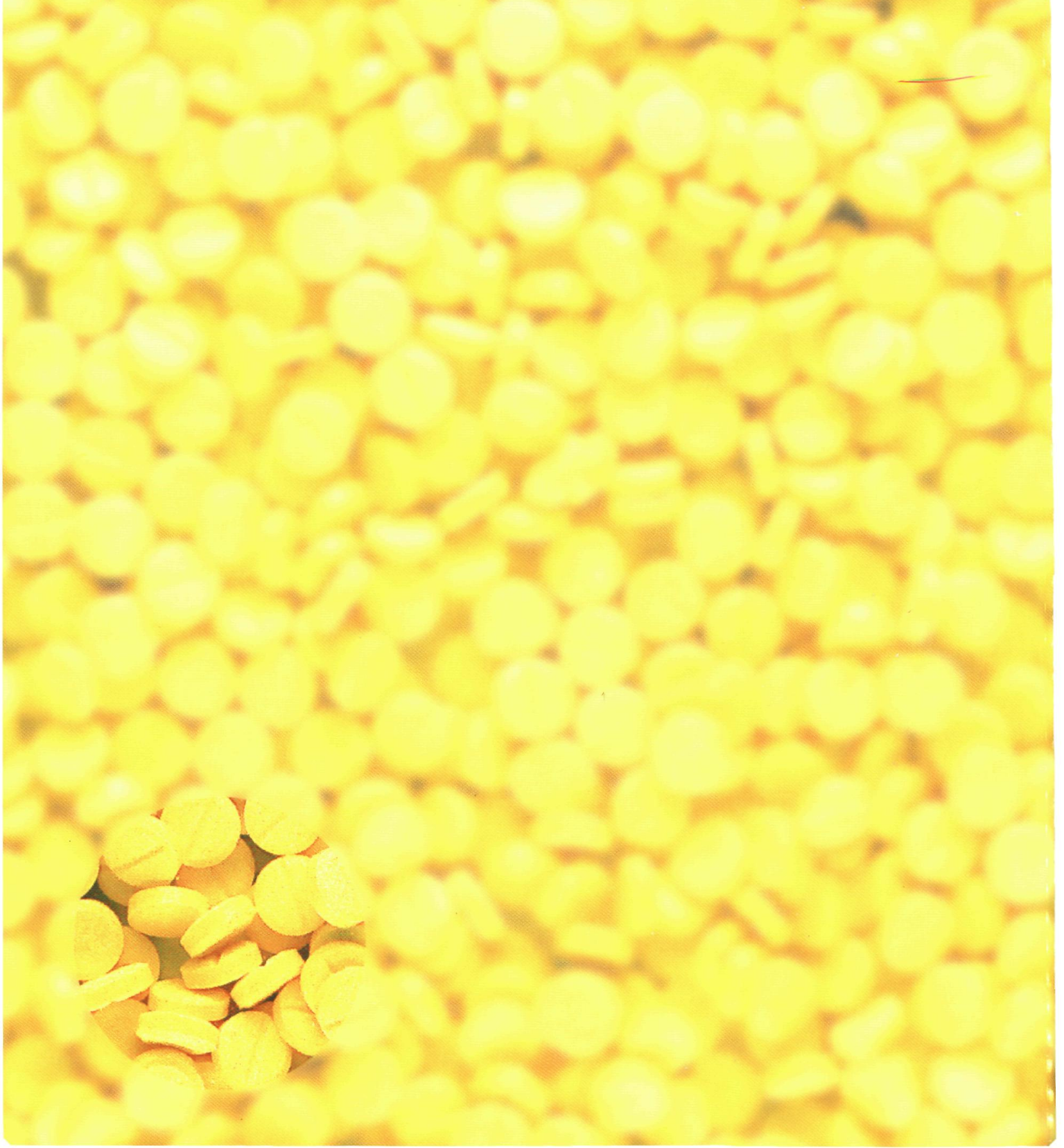

